\title{
RESTRAINING FORCED MARRIAGE
}

\author{
Lisa V. Martin*
}

\begin{abstract}
Although long a component of international women's human rights platforms, forced marriage is only presently gaining attention as a critical problem in the United States. In recent years, a number of states have considered legislation to redress forced and child marriage, most by increasing the minimum age to marry and/or mandating judicial approval of marriages involving minors. Although civil marriage reform is important, it alone is insufficient to combat forced marriage. Even where civil marriage is limited to adults, minors remain vulnerable to forced customary, religious, common law marriages, and marriages consecrated abroad. Further, intended spouses of all ages remain vulnerable to conduct intended to coerce their consent to marry. To prevent and redress forced marriage, potential victims need ready access to emergency civil injunctive relief. Civil protection orders are the central civil injunctive remedy relied upon to address intimate partner violence, rape, and stalking in the United States. The expedited and flexible remedies of civil protection orders could also help combat forced marriages; however, common legal standards create barriers to relief for those vulnerable to forced marriage. This Article is the first to undertake a detailed evaluation of the viability of civil protection orders to prevent and redress forced marriage. Although protection orders show promise as a tool to prevent and redress forced marriage in many states, the nuances of the governing legal standards reduce the practical utility of the remedy for those who lack expert guidance. To enhance the accessibility of protection orders in the context of forced marriage, this article proposes that states create a new forced marriage protection order like that established in the United Kingdom to address the specific needs of those facing this problem.
\end{abstract}

TABLE OF CONTENTS

I. FORCED MARRIAGE IN THE UNITED STATES .................................. 924

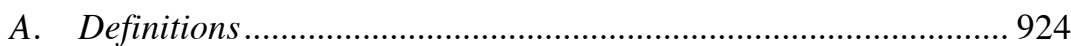

B. The Scope of the Problem .................................................... 928

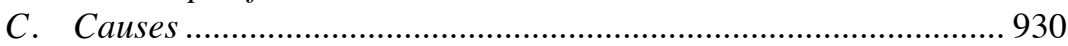

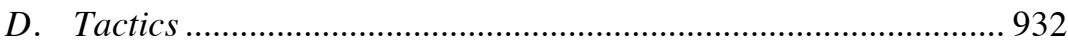

* Assistant Professor of Law, University of South Carolina School of Law. For their helpful review and comments, I am grateful to Professors Leigh Goodmark, Natalie Nanasi, and Marcia Zug. I thank Jeanne Smoot and Casey Swegman of the Tahirih Justice Center's Forced Marriage Initiative, and the participants in the works in progress sessions of the 2017 American Association of Law Schools Conference on Clinical Legal Education and the 2016 Southern Clinical Conference for sharing their insights and helping to refine my ideas. I also thank Law Librarians Emily Black and Candle Wester and Research Assistants Katherine York and Sara Ensenat for excellent research support. 
E. Consequences 933

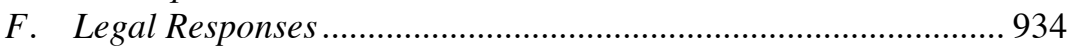

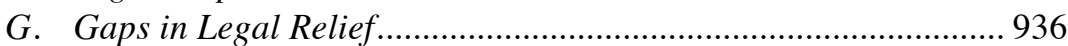

II. The Viability OF CIVIL PROTECTION ORDERS TO PREVENT

FORCED MARRIAGE ................................................................ 940

A. The History and Goals of Civil Protection Orders ..................... 940

B. The Potential for Civil Protection Orders to Prevent Forced Marriage ................................................................................ 942

C. The Fit of Civil Protection Orders to the Problem of Forced Marriage ............................................................................. 943

1. Qualifying Relationships .................................................. 944

a. Parents .................................................................... 944

b. Family and Household Members .................................. 945

c. Intended Spouse ............................................................ 946

d. Crime-Based Relationships ........................................ 947

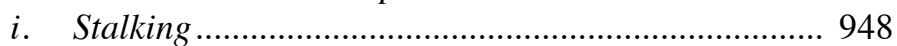

ii. Sexual Assault ................................................. 948

2. Qualifying Conduct ........................................................... 949

a. Physical Violence ....................................................... 950

b. Rape ......................................................................... 951

c. Non (Physically) Violent Conduct ................................... 954

i. Child Endangerment/Contributing to the Delinquency of a Minor ............................................................ 955

ii. Stalking and Harassment ....................................... 956

iii. Criminal Coercion/Restraint of Liberty .................. 957

iv. Emotional Abuse ............................................... 958

d. Constitutionally Protected Parental Conduct ................. 958

3. The Impediments of Minority ............................................. 960

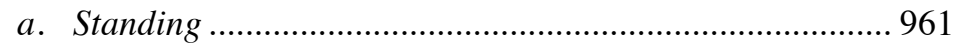

b. Capacity ...................................................................... 965

4. Remedies ........................................................................ 968

D. The Efficacy of Civil Protection Orders to Prevent Forced

Marriage ................................................................................. 969

III. RESTRAINING FORCED MARRIAGE .................................................. 970

A. Specialization ................................................................ 971

1. A Model for Reform ..................................................... 971

2. Forced Marriage as the Relationship ................................ 972

3. Forced Marriage as the Conduct ...................................... 973

4. Targeted Solutions .......................................................... 975

5. Publicizing Relief.......................................................... 975

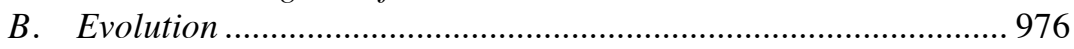

1. Moving Away from the Criminal Paradigm ........................ 976

2. Toward the Perspective of the Targeted ............................. 977

3. Toward a Presumption of Access ....................................... 978 
C. Circumspection 979

1. Feasibility ....

2. Enforceability

3. Desirability

CONCLUSION 983

APPENDIX 1: MINOR QUALIFYING RELATIONSHIPS* (STANDING) INCLUDE AGE

RESTRICTIONS AS NOTED 985

APPENDIX 2: QUALIFYING ADULT REPRESENTATIVES DESIGNATED By

PROTECTION ORDER STATUTES .. 990

APPENDIX 3: QUALIFYING CONDUCT 995

APPENDIX 4: STATE PROTECTION ORDER STATUTES EXPLICITLY ADDRESSING LEGAL CAPACITY OF MINORS 999

APPENDIX 5: ADULT QUALIFYING RELATIONSHIPS CHART. 1001

\section{INTRODUCTION}

Sara Tasneem's father forced her to marry a stranger in a religious ceremony in California when she was fifteen years old. At the time, she had no interest in marriage. She was focused on school and dreamed of becoming an attorney. After her marriage, she was taken out of the country, impregnated, and eventually returned to the United States to marry in a civil ceremony. ${ }^{1}$ Sara's father had "an abusive personality," and she felt unable to defy his plans for her marriage. Had she tried, Sara would have had few options. ${ }^{2}$

Although long recognized as a social problem at the international level, forced marriage-a marriage that lacks the consent of one or both spouses - is only now ${ }^{3}$ gaining similar attention in the United States. ${ }^{4}$ No national data ex-

${ }^{1}$ Ms. Tasneem's is identified only by her first and middle names to protect her from further issues. David Whiting, California Lacks Minimum Marriage Age, Puts Children in Danger, ORANGE CTY. REG. (June 15, 2017), http://www .ocregister.com/2017/06/15/california-lacksminimum-marriage-age-puts-children-in-danger/ [https://perma.cc/DH9J-ND35].

${ }^{2} I d$.

${ }^{3}$ Ramatu Bangura et al., A Closer Look at Forced and Early Marriage in African Immigrant Communities in New York City, 3 SAuti Yetu OcCASIONAL ReP. 1, 1 (2012), http://victimsofcrime.org/docs/nat-conf-2013/handout-2.pdf?sfvrsn=2 [https://perma.cc/U5

EQ-425P]; Vidya SRi \& Darakshan Raja, Voices From the Frontline: AdDressing ForCED MARRIAGE Within THE UNITED STATES 5 (2013), http://projects.iq.harvard .edu/files/ carrcenter/files/vidyasri_voicesfromthefrontline.pdf?m=1406738934 [https://perma.cc/JH73$\mathrm{X} 22 \mathrm{E}]$.

${ }^{4}$ See, e.g., Associated Press, States Make New Push to Curb Child Marriage, N.Y. Times (Feb. 20, 2016), https://nyti.ms/1mOVKm0 [https://perma.cc/ULW8-QXPQ]; Heather Barr, A Key Step Toward Ending Child Marriage in New York: Governor's Support of Proposed Law Boosts Chances of Success, HuM. RTs. WATCH, (Mar. 1, 2017, 12:59 PM), https://www.hrw.org/print/300729 [https://perma.cc/9WW6-FQHY]; Lisa W. Foderaro, It's Legal for 14-Year-Olds to Marry. Should It Be?, N.Y. TIMES (Mar. 13, 2017), https://nyti.ms/2neZOBe [https://perma.cc/2NHU-DS9C] (describing a case of a fifteenyear-old forced to marry a twenty-one-year-old cousin); Eleanor Goldberg, New York's 
ists on the extent of the problem in the U.S., but a growing record of quantitative studies and anecdotal accounts indicate that forced marriage is a widespread concern. ${ }^{5}$ Advocates, individuals subjected to forced and child marriage, and concerned youth have increased their collective lobbying efforts and spurred state legislatures to address the problem. Since 2016, twelve states have considered legislation to further restrict the civil marriage of minors and four have adopted reforms. ${ }^{6}$ Although tightening marriage laws has strong symbolic value and may be an effective remedy for some, civil marriage reform does not redress the plight of girls like Sara Tasneem, who are forced into marriages in circumstances that evade state attention. The issuance and denial of marriage licenses constitutes the state's primary tool to enforce civil limitations on mar-

Child Marriage 'Ban' Still Doesn't Protect Girls, HufFington Post (June 21, 2017, 9:01 AM), https://www.huffingtonpost.com/entry/new-york-finally-banned-child-marriage_us_59 49738ee4b0e84975504d42 [https://perma.cc/89FT-JLPQ] (criticizing the N.Y. legislation, saying that it does not go far enough to protect girls from forced marriages); Anna Gronewold, Advocates Demand New York Lawmakers Outlaw Child Marriage, SeATTLE TimeS (Feb. 14, 2017, 7:50 PM), http://www.seattletimes.com/nation-world/advocates-demandnew-york-lawmakers-outlaw-child-marriage/ [https://perma.cc/2XUX-KUG8]; Shanika Gunaratna, The "Ugly" Reality of Child Marriage in the U.S., CBS News (May 5, 2017, 3:47 PM), http://www.cbsnews.com/news/child-marriage-in-the-u-s-surprisingly-widespr ead/ [https://perma.cc/NU9A-9JM7] (highlighting the legality of child marriage in most states); Nicholas Kristof, 11 Years Old, a Mom, and Pushed to Marry Her Rapist in Florida, N.Y. TIMES (May 26, 2017), https://nyti.ms/2r51YnQ [https://perma.cc/878A-T6RN]; Fraidy Reiss, Why Can 12-Year-Olds Still Get Married in the United States?, WASH. Post (Feb. 10, 2017), https://www.washingtonpost.com/posteverything/wp/2017/02/10/why-does-the-uni ted-states-still-let-12-year-old-girls-get-married/?utm_term=.6d4ca4fce462 [https://perma.c c/9G23-BMNH]; Anjali Shastry, Va., Md. Weigh Raising Marriage Age to 18 to Combat Coercion, Abuse, WASH. TIMES (Feb. 15, 2016), http://www.washingtontimes.com/news/ 2016/feb/15/virginia-maryland-weigh-raising-marriage-age-to-18/ [https://perma.cc/RQ7QCRGR] (discussing states who have legislation to raise marriage age minimums on the books); Alison Thoet, New Jersey Lawmakers Pass Bill Banning Child Marriage, PBS NEwSHOUR (Mar, 14, 2017, 3:58 PM), http://www.pbs.org/newshour/rundown/new-jerseyjust-became-first-state-completely-ban-child-marriage/ [https://perma.cc/YAC4-L38B] (discussing New Jersey's law raising the age requirement of marriage to 18); Anjali Tsui, In Fight over Child Marriage Laws, States Resist Calls for a Total Ban, PBS FRONTLINE (July 6, 2017), http://www.pbs.org/wgbh/frontline/article/in-fight-over-child-marriage-laws-statesresist-calls-for-a-total-ban/ [https://perma.cc/M4TM-UF6E] (discussing different approaches to child marriage legislation); Debra Cassens Weiss, US Laws Have Allowed Children as Young as 12 to Get Married, A.B.A J. (Feb. 14, 2017, 7:00 AM), http://www.abajour nal.com/news/article/us_laws_have_allowed_children_as_young_as_12_to_get_married [ht tps://perma.cc/M2FA-5KE2] (pointing out that the laws allow for 12-year-olds to marry); Whiting, supra note 1.

${ }^{5}$ See infra Part I.

${ }^{6}$ See infra Section I.G. Although the nominal age of marriage is eighteen in most states, numerous exceptions permit minors to marry with parental consent or judicial approval under certain circumstances. Understanding State Statutes on Minimum Marriage Age and Exceptions, TAHIRIH JUST.CTR., 1 (2016), https://www.tahirih.org/wp-content/uploads/2016/ 11/FINAL-State-Marriage-Age-Requirements-Statutory-Compilation-PDF.pdf [https://per ma.cc/JLG6-E528]. 
riage before marriages occur. Yet, although marriage licenses are required or at least useful in many states to ensure that spouses have access to the legal rights and protections conferred upon married couples, marriage licenses are not required for religious or customary marriage ceremonies to take place, nor for marriages ceremonies to occur abroad. Armed with advanced knowledge of her impending religious marriage ceremony, Sara needed access to legal relief to prevent her father from orchestrating her marriage and removal from the country. To pursue such relief, Sara would have needed to know that a remedy existed and that she could qualify, and, especially given her age and maturity, she would have needed to know where to turn for help.

No civil legal remedies designed to prevent or intervene in a forced marriage currently exist in the United States. ${ }^{7}$ Most community-based organizations lack programs and services relating to forced marriage, and may not know how to respond if approached for help. ${ }^{8}$ These gaps in services and the law leave girls like Sara at the mercy of those determined to force them into marriages.

Civil protection orders have emerged as the central legal remedy in the United States to address a number of forms of gender-based violence, including domestic and dating abuse, sexual assault, and stalking. ${ }^{9}$ As forced marriage continues to emerge as another form of violence against women and girls, ${ }^{10}$ the time is ripe to evaluate the viability of civil protection orders to combat forced

${ }^{7}$ See, e.g., Julia Alanen, Custom or Crime?: Part III of IV: Crafting a Competent Framework to Combat Forced Marriage, 30 AM. J. FAM. L. 121, 121 (2016); ANGELA VigiL, A.B.A. Commission on Domestic \& Sexual Violence Report to the House of DELEGATES 5 (2014) [hereinafter VigIL, REPORT TO THE HOUSE].

${ }^{8}$ Heather Heiman \& Jeanne Smoot, Tahirih Just. Ctr., Forced Marriage in ImMigRant COMmunities IN THE United States: 2011 NATIONAL SuRvey Results 5 (2011).

${ }^{9}$ See infra Section II.A.

${ }^{10}$ Although forced marriage is recognized as a form of violence rooted in gender inequality and predominantly inflicted upon women and girls, it is important to note that men also experience this problem. In the United Kingdom, requests for assistance from male victims comprised 20 percent of the government's Forced Marriage Unit caseload in 2016, 20 percent in 2015, and 21 percent in 2014. ForEIGn \& COMMONWEALTH OfFICE, ForCED MARRIAGE UNIT STATISTICS 2016, at 3 (2017), https://www.gov.uk/government/uploads/sys tem/uploads/attachment_data/file/597869/Forced_Marriage_Unit_statistics-_2016.pdf [ht tps://perma.cc/78S3-MMBS] [hereinafter UK Statistics 2016]; ForEIGN \& COMMONwEALTH OFFICE, ForCED MARRIAGE UNIT STATISTICS 2015, at 3 (2016), https://www.gov.uk/gov ernment/uploads/system/uploads/attachment_data/file/505827/Forced_Marriage_Unit_stat istics_2015.pdf [https://perma.cc/6E8K-R2FR]; FOREIGN \& COMMONwEALTH OfFICE, ForCED MARRIAGE UNIT STATISTICS JANUARY TO DECEMBER 2014, https://www.gov.uk/government/uploads/system/uploads/attachment_data/file/412667/FMU _Stats_2014.pdf [https://perma.cc/93AJ-Q5VK]; see also EDWIGE RUDE-ANTOINE, CounCIL of Eur: Directorate Gen. of Hum. RTS., Forced Marriages in Council of Europe Member States: A Comparative Study of Legislation and Political Initiatives 23 (2005), http://eige.europa.eu/resources/CDEG(2005)1_en.pdf [https://perma.cc/F972-ERVL] (describing male victims of forced marriage in France). 
marriage. ${ }^{11}$ This Article undertakes a detailed analysis of the efficacy of civil protection orders in this context, and offers a preventive solution to the growing problem of forced marriage.

The Article proceeds in three parts. Part I explores the problem of forced marriage in the United States, including its causes and consequences, as well as recent state legislative responses and possible channels for legal intervention. This analysis identifies civil protection orders as the existing legal remedy with the most promise to prevent forced marriages. Part II evaluates in detail the viability of civil protection orders to prevent and intervene in forced marriages. This Part identifies four features of protection order statutes that determine their utility in the forced marriage context: the designations of qualifying relationships and qualifying conduct, the treatment of minor petitioners, and the range of remedies that courts may include in approved orders. Part II concludes that under certain circumstances, civil protection orders could be effective at combatting forced marriages in many states. Yet, protection order statutes are an imperfect fit for forced marriage, and would exclude many at-risk individuals from relief. Consequently, Part III proposes that states adopt a new injunctive remedy specifically crafted to address forced marriage-forced marriage protection orders. Modeled from the remedy adopted in the United Kingdom, forced marriage protection orders would center the court's inquiry on whether a petitioner was facing or had experienced a forced marriage, and would empower courts to tailor remedies to the needs of each petitioner. By moving away from a criminal paradigm, adopting a proactive orientation, incorporating a petitioner-centered perspective, and explicitly extending the remedy to minors, forced marriage protection orders also would represent a new evolution in civil injunctive relief that could redress many critiques raised of civil protection orders, and provide a model for reform of those laws. Finally, Part III recognizes and responds to potential concerns with the feasibility, enforceability, and desirability of creating forced marriage protection orders. I conclude that the potential benefits of targeted relief outweigh the potential drawbacks of failing to restrain forced marriage.

\section{ForCED MARRIAGE IN THE UNITED STATES}

\section{A. Definitions}

The right to choose the timing of one's marriage and the identity of one's spouse is widely recognized as a universal human right. ${ }^{12}$ The United States

${ }^{11}$ Elizabeth M. Landau, Custom or Crime?: Part II of IV: Legal Remedies for Forced Marriage Victims and Survivors, 30 AM. J. FAM. L. 46, 50 (2016) (suggesting protection orders as a possible remedy); Julia Alanen, Shattering the Silence Surrounding Forced and Early Marriage in the United States, 32 CHILD. LEGAL RTS. J. 1, 12 (2012) (same). 
Supreme Court has firmly established marriage as a fundamental constitutional right and a protected relationship, and has held that personal decisions relating to marriage are protected by the due process clause. ${ }^{13}$ As marriage is at its essence a contract, ${ }^{14}$ consent is central to a marriage's legal validity. ${ }^{15}$

Forced marriages lack "the full and free consent of one or both parties and typically [involve] force, fraud, or coercion." ${ }^{16}$ Forced marriage is a problem in its own right, and it overlaps with other exertions of power and control within personal and family relationships. Forced marriage has been recognized as a

${ }^{12}$ See, e.g., U.N. Comm. on the Elimination of Discrimination against Women, Convention on the Elimination of All Forms of Discrimination Against Women: General Recommendation No. 21 (1994), http://www.un.org/womenwatch/daw/cedaw/recommendations/recom

m.htm\#recom19 [https://perma.cc/5CX8-2QJV] [hereinafter Recommendation 21] ("A woman's right to choose a spouse and enter freely into marriage is central to her life and to her dignity and equality as a human being."); G.A. Res. 34/180, Convention on the Elimination of All Forms of Discrimination Against Women, art. 16(1) (Dec. 18, 1979) ("State Parties shall take all appropriate measures to eliminate discrimination against women in all matters relating to marriage and family relations and in particular shall ensure, on a basis of equality of men and women: ... The same right freely to choose a spouse and to enter into marriage only with their free and full consent. ...”); G.A. Res. 2200A (XXI), International Covenant on Economic, Social, and Cultural Rights, art. 10(1) (Dec. 16, 1966) ("Marriage must be entered into with the free consent of the intending spouses."); G.A. Res. 2200A (XXI), International Covenant on Civil and Political Rights, art. 23(3) (Dec. 16, 1966) ("No marriage shall be entered into without the free and full consent of the intending spouses."); G.A. Res. 217A (III), Universal Declaration of Human Rights, art. 16(2) (Dec. 10, 1948) ("Marriage shall be entered into only with the free and full consent of the intending spouses.").

${ }^{13}$ Obergefell v. Hodges, 135 S. Ct. 2534, 2599 (2015) (holding that the Court has long held the right to marry is in the due process clause, in part, because, "the right to personal choice regarding marriage is inherent in the concept of individual autonomy"); Loving v. Virginia, 388 U.S. 1, 12 (1967) (marriage is "one of the vital personal rights essential to the orderly pursuit of happiness by free men"); see also Zablocki v. Redhail, 434 U.S. 374, 383 (1978) (relying on Loving to hold that a requirement that fathers with outstanding child support obligations must secure judicial permission to remarry unconstitutionally infringed on the fundamental right to marry). See generally SANFORD N. KATZ, FAMILY LAW IN AMERICA 32-35 ( $2 \mathrm{~d}$ ed. 2015) (summarizing U.S. Supreme Court precedent establishing marriage as a fundamental right); Natalie Nanasi, An "I Do" I Choose: How the Fight for Marriage Access Supports a Per Se Finding of Persecution for Asylum Cases Based on Forced Marriage, 28 COLUM. J. GENDER \& L. 48, 74-80 (2014) (same).

${ }^{14}$ KATZ, supra note 13, at 29-31.

${ }^{15}$ Id. at 37-40; Nanasi, supra note 13, at 73-74.

${ }^{16}$ Casey Swegman, The Intersectionality of Forced Marriage with Other Forms of Abuse in the United States, VAWNET.ORG 1 (2016) http://www.tahirih.org/wpcontent/uploads/2016/02/AR_ForcedMarriage.pdf [https://perma.cc/4JP9-EPDE]; see also Foreign \& COMmonwealth OfFice, Forced Marriage: A Wrong Not a Right ch. 1 (2005), http://webarchive.nationalarchives.gov.uk/20080305143653/http://www.fco.gov.uk/ Files/kfile/forcedmarriageconsultation\%20doc.pdf [http://perma.cc/JLR9-UGU3] [hereinafter A Wrong Not A Right]; HeIMAN \& SMOOT, supra note 8, at 2; see also sources cited supra note 12 . 
form of domestic abuse, a form of honor violence, and a violation of human rights. ${ }^{17}$

Forced marriages differ from arranged marriages, which remain "a longstanding tradition in many cultures and countries." 18 "In arranged marriages, the families of both spouses take a leading role in arranging the marriage but the choice whether to accept the arrangement remains with the individual." 19 Forced marriages also differ from child or "early" marriages, in which one or both spouses is a minor. ${ }^{20}$

The presence or absence of consent distinguishes arranged from forced marriages, and forced from child marriages. But the boundaries between these different marriage categories sometimes blur. ${ }^{21}$ Because consent is personal to the individual and individuals may be unclear about their feelings, it can be difficult for those on the outside to identify a marriage as forced.

As another example of overlap between these marriage categories, spousal age is a central concern in forced marriage prevention efforts. Forced marriage concerns relating to spousal age include that: a significant number of forced

${ }^{17}$ See supra note 16 and accompanying text; see also, e.g., U.N. Comm. on the Elimination of Discrimination against Women, Convention on the Elimination of All Forms of Discrimination Against Women: General Recommendation No. 19, Comment Articles 2(f), 5 and 10(c) (1992), http://www.un.org/womenwatch/daw/cedaw/recommendations/recomm.ht

m\#recom19 [https://perma.cc/5CX8-2QJV] ("Traditional attitudes by which women are regarded as subordinate to men or as having stereotyped roles perpetuate widespread practices involving violence or coercion, such as ... forced marriage. ... Such prejudices and practices may justify gender-based violence as a form of protection or control of women. The effect of such violence on the physical and mental integrity of women is to deprive them the equal enjoyment, exercise and knowledge of human rights and fundamental freedoms."). The U.S. State Department recognizes forced marriage as "a violation of basic human rights," and "a form of child abuse," when a minor is involved. U.S. DEP'T OF STATE, 7 FOREIGN AFFAIRS MANUAL (FAM): FORCED MARRIAGE OF MiNORS 1741(a) (2005), https://fam.state.gov/FAM/ 07FAM/07FAM1740.html [https://perma.cc/J369-2BVC] [hereinafter FAM].

${ }^{18}$ FAM, supra note 17 , at 1743 .

${ }^{19}$ Id.; see also A WrONG NOT A Right, supra note 16.

${ }^{20}$ Children are permitted to marry under limited circumstances in all fifty states. Research of state marriage data indicates that at least 207,468 minors married in the United States between 2000 and 2015. Anjali Tsui et al., Child Marriage in America: By the Numbers, PBS FRONTLINE (July 6, 2017), http://apps.frontline.org/child-marriage-by-the-numbers/ [http:// perma.cc/MH36-TD5S]. This number likely underreports the problem, as it includes data from only forty-one states and that data includes gaps in years and counties reporting in some states. Id. "Advocates in the United States differ with respect to whether child marriage can be directly equated with forced marriage." Swegman, supra note 16, at 3 .

${ }^{21}$ Julia Alanen, Custom or Crime? (Part I of IV): Catalysts and Consequences of Forced Marriage, 29 AM. J. FAM. L. 227, 227 (2016); see also Shamita Das Dasgupta, Foreword to Vidya SRi \& DARAKSHAN RAJA, Voices From the Frontline: AdDRESSing Forced MARRIAGE Within the United STATES 4 (2013) (“arranged and forced marriages may be viewed as points on a continuum of 'persuasion' that stretches between two extremes: mild request and severe abuse.”). 
marriage victims are minors; ${ }^{22}$ a minor may not be psychologically prepared to make major life decisions ${ }^{23}$ the social norms and legal structures that place minors under parental control make them especially vulnerable to forced marriages promoted by their parents or guardians ${ }^{24}$ and child brides face an increased risk of abuse within marriage ${ }^{25}$ and health risks from early pregnancies. ${ }^{26}$ Finally, minors who are forced to marry often marry adults, which may increase their vulnerability in the marriage, ${ }^{27}$ and make them legally unable to consent to sex under statutory rape laws. ${ }^{28}$ On the other hand, concerns about preserving the autonomy of older minors, and the recognition that minors may have legitimate reasons to marry before they reach eighteen years of age, have contributed to a robust debate within the United States as to whether and under what circumstances minors should be deemed capable to consent to marry. ${ }^{29}$ Although concerns particular to minors often are raised in forced marriage literature, the problem of forced marriage is not limited to children. The U.S. Department of

${ }^{22}$ Bangura et al., supra note 3, at 1; HeIMAN \& SMOOT, supra note 8, at 2; Swegman, supra note 16 , at 3 .

${ }^{23}$ U.N. Convention on the Elimination of All Forms of Discrimination Against Women, Joint General Recommendation No. 31 of the Committee on the Elimination of Discrimination Against Women/General Comment No. 18 of the Committee on the Rights of the Child on Harmful Practices, at 7, U.N. Doc. CEDAW/C/GC/31-CRC/C/GC/18 (Nov. 14, 2014) [hereinafter Recommendation 31].

${ }^{24}$ See generally 1 Donald T. KRAmer, Legal Rights of ChILDRen at v-vi (rev. $2 \mathrm{~d}$ ed. 2005).

${ }^{25}$ Judith McFarlane et al., Child Brides, Forced Marriage, and Partner Violence in America: Tip of an Iceberg Revealed, 127 OBSTETRICS \& GyNECOLOGY 706, 706 (2016); Swegman, supra note 16, at 3.

${ }^{26}$ Recommendation 31, supra note 23, at 7, 22.

27 Tsui et al., supra note 20 (86 percent of minors married between 2000-2015 married adults).

${ }^{28}$ See infra note 209 and accompanying text.

${ }^{29}$ The United Nations Division for the Advancement of Women, for example, considers all child marriages to be forced because children under eighteen are incapable of giving a valid consent to marriage. Cheryl Thomas, Forced and Early Marriage: A Focus on Central and Eastern Europe and Former Soviet Union Countries with Selected Laws from Other Countries, U.N. Doc. EGM/GPLHP/2009/EP.08. Many international human rights instruments and recommendations from human rights bodies promote eighteen as the appropriate minimum age to marry for boys and girls. See, e.g., Recommendation 21, supra note 12 ("the Committee considers that the minimum age for marriage should be 18 years for both man and woman. When men and women marry, they assume important responsibilities. Consequently, marriage should not be permitted before they have attained full maturity and capacity to act."). On the other hand, organizations including the ACLU and the Women's Law Center of Maryland have argued that total bans on marriage before eighteen undermine the autonomy of older minors and infringe upon the fundamental right to marry. Tsui et. al., supra note 4 . Other groups have objected that marriage provides one of only a few viable paths to emancipation and exit from the foster care system, and that minors may want their children to be born to married parents. Id. 
State has recognized that those most at risk of forced marriages fall between the ages of thirteen and thirty. ${ }^{30}$

Free and full consent to marriage not only requires that an individual approves of the idea of marriage, its timing, and the intended partner; but also that the individual can reject a proposed marriage without facing significant negative repercussions.$^{31}$ Forced marriages include any marriage that one party is unable to end or leave, even if the marriage was initially entered consensually. ${ }^{32}$

\section{B. The Scope of the Problem}

Forced marriages take many forms. They include civil marriages recognized under state and federal laws, marriages sanctified by religious or customary/traditional authorities, informal cohabitation recognized as a marriage by the family and community, or some combination of the three..$^{33}$ Forced marriages can involve U.S. citizens or immigrants, and take place both within the United States and abroad, after a victim is tricked or coerced into traveling to her family's home country. ${ }^{34}$

National data on the prevalence of forced marriage is nonexistent in the United States. ${ }^{35}$ The little information that does exist stems from surveys of community-based service providers and localized surveys of individuals from particular communities or settings. ${ }^{36}$ Although much remains unknown about the issue, anecdotal findings in three distinct contexts suggest a broader problem. ${ }^{37}$

First, forced marriage is an identifiable issue facing clients of communitybased organizations throughout the United States. A voluntary survey of organizations in forty-seven states identified as many as 3,000 forced marriage cases

${ }^{30}$ FAM, supra note 17.

${ }^{31}$ Swegman, supra note 16 , at 2.

${ }^{32}$ U.N. High Comm'r for Human Rights, Preventing and Eliminating Child, Early and Forced Marriage, I 6, U.N. Doc. A/HRC/26/22 (Apr. 2, 2014) (“A forced marriage is any marriage which occurs without the full and free consent of one or both of the parties and/or where one or both of the parties is/are unable to end or leave the marriage, including as a result of duress or intense social or family pressure.").

${ }^{33}$ Bangura et al., supra note 3, at 4. Customary or traditional marriages are conducted according to the laws or beliefs of a cultural group that may or may not have a basis in religion. Id. at Terminology.

${ }^{34}$ FAM, supra note 17, at 1743.1-.3; HeIMAN \& SMOOT, supra note 8, at 8; McFarlane et al., supra note 25 , at $708-09$.

${ }^{35}$ Cynthia Helba et al., Report on Exploratory Study into Honor Violence MEASUREMENT METHODS 3-3 (2014); SRI \& RAJA, supra note 3, at 8 . There are many challenges to collecting valid quantitative data on forced marriage, including the many forms of unregistered and informal marriages. Thus, many countries must rely on anecdotal data and small-scale studies to understand the problem. See, e.g., RuDE-ANTOINE, supra note 10, at 22 .

${ }^{36}$ HelBA ET AL., supra note 35, at 7-3.

${ }^{37}$ HeIMAN \& SMOOT, supra note 8 , at 3. 
over a two-year period. ${ }^{38}$ This number is particularly striking because the vast majority of respondents reported that their agency neither screened for, nor offered assistance related to, forced marriage at the time. ${ }^{39}$ The survey identified reports of forced marriage involving women originating from fifty-six different countries and, although it focused on immigrant women, also produced reports of forced marriage within non-immigrant American families. ${ }^{40}$

Second, women receiving services for domestic abuse report experience with forced marriage in significant numbers. In a 2016 study of mothers subjected to intimate partner violence, 17 percent of the 277 participants reported having been forced to marry or subjected to a forced marriage attempt. ${ }^{41}$ At the time of these reported incidents, nearly half of the participants were under the age of eighteen, most were U.S. citizens, and the vast majority were in the United States. ${ }^{42}$ Most neither sought nor received assistance. ${ }^{43}$ When they did reach out for help, most confided in friends or family members; few turned to formal sources of support. ${ }^{44}$

Third, the pressure for girls to marry is pervasive within some communities. In one study, twenty-eight out of thirty young female clients of an organization serving West African immigrants had been pressured to marry or were married before they reached eighteen years of age.$^{45}$ In another study, students of Middle Eastern, North African, and South Asian descent at the City University of New York revealed frequent anxiety and family tension regarding marriage. ${ }^{46}$ Forced marriage practices also have been documented within several non-immigrant conservative religious groups. ${ }^{47}$

${ }^{38} I d$. at 7 . Of the more than 500 agencies that responded to the survey, 41 percent reported at least one known or suspected case of forced marriage during 2009-2011. Id.

${ }^{39} I d$. at 5-6. Half of the survey respondents reported that forced marriages usually or always occurred before the victim was connected to the agency. Id. at 7 . Only 22 percent of respondents reported having screening processes that would enable them to identify forced marriage concerns. $I d$. at 5 . Less than 16 percent reported that their agency would be able to assist individuals facing forced marriage if cases were identified. $I d$. at 6 .

${ }^{40} I d$. at 7. The countries most frequently identified included India, Pakistan, Mexico, Bangladesh, the Philippines, Afghanistan, Somalia, and Yemen. Id. Respondents also identified "over a dozen countries in Africa, numerous countries in Asia and the Middle East, and select countries in Europe and the Americas." Id.

${ }^{41}$ McFarlane et al., supra note 25, at 708. All of the study participants qualified for domestic violence shelter or a civil protection order. Id. at 707 .

${ }^{42} I d$. at 708-09 (noting that 45 percent reported the forced marriage or attempt occurring when they were under eighteen; 74 percent were U.S. citizens; 85 percent reported that the forced marriage or attempt occurred in the United States).

${ }^{43} I d$. at 708.

${ }^{44} \mathrm{Id}$. at 710.

${ }^{45}$ Bangura et al., supra note 3 , at 9 . Only six of the girls "outwardly resisted" early marriage and two fully consented. Id.

${ }^{46}$ See generally Anthony Marcus et AL., Is Forced Marriage a Problem in the United STATES? 2, http://www.theahafoundation.org/wp-content/uploads/2015/03/AHA_ForcedMarriage-Report.pdf. [https://perma.cc/82GH-HQ49] (last visited May. 8, 2018). See also 


\section{Causes}

Forced marriage is driven by a number of factors. ${ }^{48}$ Three common motivators in the United States include pregnancy, honor, and tradition. Pregnancy contributes to forced marriages because of social views that sex, pregnancy, and childbirth should occur exclusively within marriage. As one example, Keith Strawn drove his fourteen-year-old daughter from Idaho to Missouri to take advantage of a Missouri law permitting younger minors to marry. ${ }^{49}$ In Missouri, Strawn forced his daughter to marry her twenty-four-year-old rapist because she was pregnant, and Strawn believed that men must marry the women they impregnate..$^{50}$ Although his actions were extreme and horrifying, Strawn's worldview is no outlier in the United States. The continued recognition of the "shotgun wedding" within American popular culture points to longstanding beliefs and social pressures within some communities that a pregnancy must result in a wedding. ${ }^{51}$ The prevalence of pregnancy exceptions to minimum marriage age laws reflect the view that sex and pregnancy should occur within marriage, set up marriage as a solution to teen pregnancy, and convey

UK Statistics 2016, supra note 10, at 9 (identifying Pakistan, Bangladesh, India, Somalia, and Afghanistan as the countries related to the highest number of forced marriage reports; Pakistan had the largest share by far with 43 percent of reports, followed by Bangladesh with 8 percent).

${ }^{47}$ Esther's Story, UNCHAINED AT LAST, http://www.unchainedatlast.org/about-arrangedforced-marriage/esthers-story/ [https://perma.cc/FZF9-8JK9] (last visited May. 8, 2018) (describing a forced marriage in a Hassidic community); Kristof, supra note 4 (including stories about forced marriage in a Pentecostal church, a conservative Christian household, and an ultra-Orthodox Jewish family).

${ }^{48}$ Heiman \& SMOOT, supra note 8, at 8; Bangura et al., supra note 3, at 9; Swegman, supra note 16 , at 1 .

${ }^{49}$ E. Idaho Father Arranged Marriage of his Daughter, 14, to Man Who Got Her Pregnant, IDAHO ST. J. (May 31, 2016), http://idahostatejournal.com/members/e-idaho-father-arrangedmarriage-of-his-daughter-to-man/article_55a4c32f-605e-5081-a12e-561151a58887.html [ht tps://perma.cc/5XJQ-KFPY].

${ }^{50} I d$.

${ }^{51}$ See, e.g., DixIE CHICKS, White Trash Wedding, on Home (Open Wide/ Monument/ Columbia Records 2002) ("Baby's on its way. Say I do and kiss me quick because baby's on its way”); Kevin Fowler, Knocked Up, on CHIPPIN' AwAY (Average Joe's 2011) ("Yeah, your family's got the shotgun ready ... I can hear those church bells chime .. . No, I may not be ready for a wedding, honey . . . But I know that I ain't ready to die"); RELIENT K, Deathbed, on Five Score AND SEVEN YeARS Ago (Capitol Records 2007) ("Got married on my twentyfirst. Eight months before my wife would give birth. It's easier to be sure you love someone ... When her father inquires with the barrel of a gun"); see also NichOLAS L. SYRETT, AMERICAN CHILD BRIDE: A History OF MinORS AND MARRIAGE IN THE UNited STATES 23436 (2016) (identifying pregnancy as a cause of the rise of teen marriages following World War II, and noting that "[m]any girls, and especially those who dated young boys, were 'forced' into marriage on discovering that they were pregnant"). Men are often those forced into "shotgun" marriages. Although no reliable statistics on the number of men forced into marriages exist in the United States, data from the United Kingdom and France indicate that men consistently seek assistance (although in considerably smaller numbers than women). See ForEIGN \& COMMONWEALTH OfFICE, supra note 10. 
state support for children being born into marriages ${ }^{52}$ Teenage pregnancies in particular may lead to forced marriages, because families retain more control over the bride-to-be ${ }^{53}$ Notably, the American South and Southwest have the highest teen pregnancy rates in the country, and also the highest rates of teen marriages. ${ }^{54}$

In some cases, marriages may be forced to halt criminal rape or statutory rape investigations. At age eleven, Sherry Johnson was forced to marry a twenty-year-old man, one of two members of her church who had raped her, after child welfare officials began investigating the circumstances of her pregnancy. ${ }^{55}$ Ms. Johnson's mother and church leaders forced her to marry her attacker to protect him from criminal prosecution. ${ }^{56}$

Two additional motivators for forced marriage, which often intertwine, are adherence to tradition and preservation of family honor. ${ }^{57}$ In certain immigrant and nonimmigrant communities in the United States, it is customary for women to marry at a young age. ${ }^{58}$ Once young women reach puberty, families may take steps to remove them from corrupting influences and preserve their reputations in advance of marriage, such as withdrawing them from school or restricting their contact with non-family members. ${ }^{59}$ Families may suddenly make or accelerate marriage plans if a daughter is believed to be socializing with boys, dating, engaging in sexual activity, or is viewed as becoming "too American-

52 SYRETT, supra note 51, at 260-61.

${ }^{53}$ People v. Dozier, 424 N.Y.S.2d 1010, 1014 (N.Y. App. Div. 1980) (“The state has a legitimate concern that females sixteen years and younger do not become pregnant or suffer physical injury, and as a result, find themselves facing practical problems for which their youth has not prepared them. Forced marriage, unwed motherhood, adoption, abortion, the need for medical treatment and precipitate withdrawal from school are just some of the considerations which often have to be faced. ..."); In re Comm'r of Soc. Servs. ex rel Leslie C., 614 N.Y.S.2d 855, 860 (N.Y. Fam. Ct. 1994) ("[T]here are sound social policy reasons underlying the public policy of discouraging sexual intercourse among unwed females under the age of seventeen. Certain consequences, such as . . f forced marriage . . must invariably be faced when children bear children.").

${ }^{54}$ SYRETT, supra note 51, at 264-65.

${ }^{55}$ Kristof, supra note 4.

${ }^{56} \mathrm{Id}$.

${ }^{57}$ HeIMAN \& SMOOT, supra note 8 , at 8.

${ }^{58}$ See, e.g., Bangura et al., supra note 3, at 9; Case Swegman, Forced Child Marriage Case Scenarios for Lisa Martin (July 12, 2017) (case examples from a Christian non-immigrant religious community and a Pakistani immigrant community).

${ }^{59}$ Swegman, Forced Child Marriage Case Scenarios for Lisa Martin, supra note 58 ("Sarah," and "Halimah"); Yasmine Koenig as told to Liz Welch, My Mom Took Me Overseas and Forced Me into Being a Teen Bride, SEVENTEEN (Oct. 13, 2017), http://www.seventeen.c om/life/real-girl-stories/a40668/parents-sent-me-to-the-middle-east-to-get-married/ [https://perma.cc/FAX8-CHBE] (describing how a mother removed daughter from school after eighth grade and took her to Palestine to marry at fifteen after she was discovered to have a boyfriend, and separately forced an older sister to marry after discovering a diary entry about kissing a boy). 
ized. ${ }^{60}$ In some communities, a young woman's disobedience to any direction from the male head of the family, including a dictate to marry, is considered dishonor to her family. ${ }^{61}$ To "restore" the family's honor in the wake of disobedience, the woman may be severely punished, disowned, or even killed. ${ }^{62}$ Young women might submit to marriages they do not wish to enter, or remain in marriages they otherwise would leave, out of fear that their decisions may provoke retributory violence from family members against themselves or others. ${ }^{63}$ Other common motivators behind forced marriages include parents' beliefs that a marriage serves a child's best interests; obligations to honor contracts or arrangements between families; and the desire to secure economic or immigration benefits to families or the intended spouse. ${ }^{64}$

\section{Tactics}

Individuals facing forced marriage often experience coordinated pressure from parents, relatives, friends, and community members. ${ }^{65}$ Common tactics include: parents threatening to harm or kill themselves; declaring the ruin of a family's or individual's reputation; isolation $;{ }^{66}$ social ostracization; ${ }^{67}$ threats to kick an individual out of the house or withdraw financial support; ${ }^{68}$ taking or threatening to take a child out of school; ${ }^{69}$ or threats of physical violence against the individual or others they care about. ${ }^{70}$ In more extreme cases, tactics have included physical violence or torture, ${ }^{71}$ threats of deportation, taking the individual abroad through deception, kidnapping, captivity, stalking, consecrat-

${ }^{60}$ HeImAN \& SMOOT, supra note 8 , at 8 .

${ }^{61}$ HeLBA ET AL., supra note 35, at 1-2-1-3.

${ }^{62} I d$. at 1-4, 2-5-2-6, 3-2-3-3.

${ }^{63}$ See Court Upholds Man's Sentencing in 'Honor Killing,' CBS ATL. (Jan. 22, 2013, 9:05 AM), http://atlanta.cbslocal.com/2013/01/22/court-upholds-mans-sentence-in-honor-killing/ [https://perma.cc/ 3UWD-76TN] [hereinafter CBS ATL., Honor Killing]; Dad Charged with Murdering Reluctant Bride, CNN (July 9, 2008), http://www.cnn.com/2008/CRIME/07/08/

honor.killing/\#cnnSTCText [https://perma.cc/WH5A-NZSW] [hereinafter CNN, Reluctant Bride]; see also Mosi Secret, Court Documents Detail a Deadly Family Feud from Brooklyn to Pakistan, N.Y. Times, May 22, 2013, at A26 (describing how an American citizen was forced into a marriage in Pakistan, then threatened with murder when she escaped, and those who helped her escape were killed).

${ }^{64}$ HeImAn \& SMOOT, supra note 8 , at 8.

${ }^{65}$ Bangura et al., supra note 3 , at 9.

${ }^{66}$ McFarlane et al., supra note 25, at 708-09; Debjani Roy, An Introduction to Forced Marriage in the South Asian Community in the United States, MANAVI OCCASIONAL PAPER No.9, at 22 (2011), https://web.archive.org/web/20160810073656/http://www.manavi.org/docu ments/Manavi_paper9_pass-6.26.12.pdf [https://perma.cc/DY22-YR44].

${ }^{67}$ McFarlane et al., supra note 25, at 708-09.

${ }^{68} \mathrm{Id}$.

${ }^{69}$ Roy, supra note 66, at 23.

${ }^{70}$ Heiman \& SMOOT, supra note 8, at 8; McFarlane et al., supra note 25, at 708-09.

${ }^{71}$ Roy, supra note 66, at 23; McFarlane et al., supra note 25, at 708-09. 
ing a marriage without the individual's knowledge or participation, withholding food or medical care, and even threats of murder. ${ }^{72}$

Potential forced marriage victims may know or suspect that a marriage is being planned, or they may be taken completely by surprise. Thirteen-year-old Jesse Bender fled her home in California with the support of an uncle because she feared she would be forced into a marriage during an impending family trip to Pakistan. ${ }^{73}$ Kay Gans's parents told her they were taking her and her boyfriend to a football game when they drove them to West Virginia from Ohio. ${ }^{74}$ Instead, they took Kay and her boyfriend to a county clerk's office, directed Kay to tell the clerk she was seventeen years old, consented to her marriage to her seventeen-year-old boyfriend, and saw the couple married before driving them back to Ohio. ${ }^{75}$

\section{E. Consequences}

Those facing forced marriage experience numerous harms. In contemporary U.S. society, where divorce is a commonplace and relatively accessible remedy, the harm created by the solemnization of a marriage may be difficult to understand. But forced marriages cause real and significant harm to those subjected to them, whatever the tactics involved. "Forced marriage is [a] form of violence against women in its own right, even when sexual violence and other forms of harm and abuse are not present." ${ }^{, 76}$ Forced marriage deprives a nonconsenting spouse of dignity, autonomy, and self-determination. ${ }^{77}$ Denying an individual the opportunity to choose her own life partner, and thereby the direction and circumstances of her life, communicates that her own needs or desires are unworthy of respect and secondary to the designs for her life that others have created to advance their own interests. Those forced into marriage also face rape ${ }^{78}$ domestic and family violence,${ }^{79}$ stalking, ${ }^{80}$ and, in some cultures,

72 HeImAN \& SMOOT, supra note 8, at 8. A man in Georgia was convicted of murdering his daughter after she threatened to divorce the husband that she had been forced to marry against her will. The news reports described the marriage as "arranged," but statements to the police by the victim's father's wife indicate that the marriage occurred without the victim's consent. CNN, Reluctant Bride, supra note 63; CBS ATL., Honor Killing, supra note 63; see also Secret, supra note 63 (describing how an American citizen was forced into a marriage in Pakistan, then threatened with murder when she escaped, and those who helped her escape were killed).

73 Paloma Esquivel, Girl, 13, Says She Fled Home to Avoid a Forced Marriage in Pakistan, L.A. TIMES (Mar. 4, 2011), http://articles.latimes.com/2011/mar/04/local/la-me-hesperia-girl20110304 [https://perma.cc/T7SA-XEPL].

${ }^{74}$ State v. Gans, 151 N.E.2d 709, 709 (Ohio 1958).

${ }^{75}$ Id. at 714.

${ }^{76}$ Swegman, supra note 16, at 2; see also Recommendation 31, supra note 23.

77 See Recommendation 21, supra note 12 ("A woman's right to choose a spouse and enter freely into marriage is central to her life and to her dignity and equality as a human being.").

${ }^{78}$ SRI \& RAJA, supra note 3, at 14, 21; McFarlane et al., supra note 25, at 708-09.

${ }^{79}$ MARCUS ET AL., supra note 46, at 2; SRI \& RAJA, supra note 3, at 24. 
female genital cutting (FGC) ${ }^{81}$ both before and after a marriage occurs ${ }^{82}$ all of which may lead to depression, suicide, or suicide attempts. ${ }^{83}$ Moreover, those forced into marriages who are cut off from friends and restricted in their movements may suffer isolation and lose opportunities for education and employment. ${ }^{84}$

Multiple barriers prevent individuals from escaping forced marriages. Those forced into marriages may face reprisals from family members if they resist, abandon, or seek to dissolve their unions. ${ }^{85}$ Individuals who are taken abroad to marry may be left without a passport, means of communication, or access to finances. ${ }^{86}$ For example, Yasmine Koenig was only fifteen when her parents forced her to marry a twenty-four-year-old man during a family trip to Palestine. Yasmine's parents did not tell her that they planned for her to marry before they left the United States; they told her that they were going to visit her sisters and other relatives. ${ }^{87}$ Yasmine escaped her marriage only because she had access to a cell phone. She contacted the U.S. Embassy, which arranged her transportation back to the United States after two months of furtive communications. ${ }^{88}$

\section{F. Legal Responses}

The problems of child and forced marriage in the United States recently have garnered increasing attention from state legislatures. Between 2016 and the time of this article's publication, at least eighteen states have considered bills that would reform civil marriage laws to reduce forced and child marriage by increasing the lawful marriage age, requiring judicial approval for marriages involving minors, or emancipating minors who are granted permission to marry to ensure they have the capacity to protect their own legal interests. ${ }^{89}$ At the

${ }^{80}$ Swegman, supra note 16 , at 8.

${ }^{81} I d$. at $9-10$

${ }^{82} I d$. at 6.

${ }^{83}$ SRI \& RAJA, supra note 3, at 15; HEIMAN \& SMOOT, supra note 8, at 9.

${ }^{84}$ The British Ass'N OF Soc. Workers, A Choice by Right: The Report of THE Working GROUP ON FORCED MARRIAGE 15 (2000) [hereinafter A CHOICE BY RighT].

${ }^{85}$ HelbA ET AL., supra note 35, at 3-3; SRI \& RAJA, supra note 3, at 20; Swegman, supra note 16 , at 8 .

${ }^{86}$ Eleanor Stobart, Forced Marriage Unit, Multi-agency Practice Guidelines: HANDLING CASES OF FORCED MARRIAGE 14 (2009).

${ }^{87}$ Welch, supra note 59.

${ }^{88} I d$. Upon her return to the United States, Yasmine was placed into the foster care system. She ultimately was adopted by her foster family. Id.

${ }^{89}$ S.B. 133, 30th Leg., Reg. Sess. (Alaska 2018); H.B. 2006, 53rd Leg., 2d Reg. Sess. (Ariz. 2018); H.B. 71, 2018 Leg., 120th Reg. Sess. (Fla. 2018); S.B. 140, 2018 Leg., 120th Reg. Sess. (Fla. 2018); S.B. 208, 2018 Leg., 120th Reg. Sess. (Fla. 2018); S.B. 48, 2018 Gen. Asemb., Reg. Sess. (Ky. 2018); H.B. 191, 438th Gen. Assemb., Reg. Sess. (Md. 2018); S.B. 670, 438th Gen. Assemb., Reg. Sess. (Md. 2018); H.B. 1785, 110th Gen. Assemb., 2d. Reg. Sess. (Tenn. 2018); H.B. 2521, 110th Gen. Assemb., 2d. Reg. Sess. (Tenn. 2018); H.B. 790, 
time of publication, at least four states have succeeded-Connecticut, New York, Texas, and Virginia adopted marriage reforms in 2016 and $2017 . .^{90}$ Delaware reformed its marriage law to require all minors to seek court approval to marry in $2007 .^{91}$

Separate from the recent push for marriage reform, nine states, the District of Columbia, and the U.S. Virgin Islands criminalize forced marriage. ${ }^{92} \mathrm{Al}-$ 0though the operative statutes remain good law, they appear to have little practical utility. Several of the offenses are drafted in antiquated terms and are included within statutes enacted to combat other problems, such as abduction, defilement, prostitution, and pandering. ${ }^{93}$ A few newer statutes address forced marriage in the context of human trafficking. ${ }^{94}$ Despite the fact that some of

2018 Gen. Assemb., Reg. Sess. (Vt. 2018); S.B. 273, 2018 Leg., Reg. Sess. (Cal. 2017); H.B. 5442, 2017 Gen. Assemb., Jan. Sess. (Conn. 2017); H.B. 799, 437th Gen. Assemb., Reg. Sess. (Md. 2017); S.B. 861, 437th Gen. Assemb., Reg. Sess. (Md. 2017); H.B. 2310, 190th Gen. Ct., Reg. Sess. (Mass. 2017); H.B. 2311, 190th Gen. Ct., Reg. Sess. (Mass. 2017); S.B. 785, 190th Gen. Ct., Reg. Sess. (Mass. 2017); S.B. 786, 190th Gen. Ct., Reg. Sess. (Mass. 2017); H.B. 270, 99th Gen Assemb., 1st Reg. Sess. (Mo. 2017); H.B. 499, 165th Gen. Ct., 1st year Reg Sess. (N.H. 2017); Assemb. B. 5524, 240th Leg., Reg. Sess. (N.Y. 2017); S.B. 4407, 2017 N.Y. Sess. Laws, ch. 35 (2017); S.B. 198, 132nd Gen. Assemb., Reg. Sess. (Ohio 2017); H.B. 1038, 201st Gen. Assemb., Reg. Sess. (Pa. 2017); H.B. 3932, 85th Leg., Reg. Sess. (Tex. 2017); S.B. 1705, 85th Leg., Reg. Sess. (Tex. 2017); Assemb. B. 3091, 217th Leg., 1st Ann. Sess. (N.J. 2016); S.B. 2528, 217th Leg., 1st Ann. Sess. (N.J. 2016); S.B. 415, 2016 Leg., Reg. Sess. (Va. 2016).

${ }^{90}$ H.B. 5442, 2017 Gen Assemb., Jan. Sess. (Conn. 2017); Assemb. B. 5524, 240th Leg., Reg. Sess. (N.Y. 2017); S.B. 4407, 2017 N.Y. Sess. Laws, ch. 35 (2017); H.B. 3932, 85th Leg., Reg. Sess. (Tex. 2017); S.B. 1705, 85th Leg., Reg. Sess. (Tex. 2017); S.B. 415, 2016 Leg., Reg. Sess. (Va. 2016).

${ }^{91}$ The law eliminated a prior exception, which permitted pregnant minors to marry without court approval. DEL. CODE ANN. tit. 13, 123 (2017). A parent, guardian, or next friend must petition the court for approval of the marriage on behalf of the minor to be married. Id. For more information on the laws regarding marriage age in all fifty states, see Understanding State Statutes on Minimum Marriage Age and Exceptions, supra note 6.

92 Cal. Penal Code $\S 265$ (West 2018); D.C. Code $§ 22-2705$ (2018); Md. Code Ann., CRIM. LAW § 11-303 (West 2018); MinN. STAT. § 609.265 (2017); Miss. CodE ANN. § 97-31 (2017); NeV. ReV. STAT. § 201.300 (2017); OKLA. STAT. tit. 21, §§ 1117-19 (2017); VA. Code AnN. § 18.2-355 (2017); V.I. COdE AnN. tit. 14, § 1301 (2017); W. VA. CODE § 61-214 (2017); TAhirih Justice Ctr., CRiminal Laws AdDressing ForCed Marriage in the UNITED STATES 1 (2013) [hereinafter CRIMINAL LAws]; Landau, supra note 11, at 47-49 (including California, Florida, Maryland, Minnesota, Mississippi, Nevada, Oklahoma, Virginia, and West Virginia).

${ }_{93}$ Landau, supra note 11 , at 47-49.

${ }^{94}$ CRIMINAL LAwS, supra note 92; Landau, supra note 11, at 47. The United Nations International Labor Organization and International Organization for Migration recently copublished a study recognizing forced marriage as one form of human trafficking/modern slavery. See Int'l Labour Org. (ILO) Et al., Global Estimates of Modern Slavery: FORCED LABOUR AND FORCED MARRIAGE 9 (2017). 
these statutes have existed for a century or more, researchers have been unable to identify a single prosecution for forced marriage under any of these laws. ${ }^{95}$

\section{G. Gaps in Legal Relief}

Existing marriage, criminal, child abuse and neglect, and tort laws have at least a theoretical potential to provide legal protection from forced marriage. In practice, none of these remedies is likely to provide material relief on a wide scale. For example, civil marriage laws can attempt to deter the forced marriage of minors by categorically limiting minors' access to state-sanctioned marriage and increase state scrutiny of marriages involving minors through judicial review. Although such laws may succeed in delaying or deterring the marriages of some minors, civil marriage laws do not prevent marriages from being conducted without state sanction. Marriages conducted abroad, and marriages conducted within the United States in religious or customary ceremonies are not subject to state regulation. State marriage law kicks in only once the couple seeks legal recognition by or a marriage-based benefit from the state.

The criminal justice system is also unlikely to be able to respond effectively to the problem on a wide scale for two primary reasons. First, individuals facing forced marriages are unlikely to cooperate. Those facing forced marriages often report wanting to postpone or avoid marriage without severing ties to their families, communities, and culture. ${ }^{96}$ To prevent negative repercussions for family members, those facing forced marriages have declined outside assistance if they believe it could result in prosecution, deportation, embarrassment, or separation from family members. ${ }^{97}$

Second, even where victims want to cooperate, law enforcement officers' reluctance to interfere in private family life or take a position on a "cultural" matter ${ }^{98}$ may preclude the investigation and prosecution of forced marriage

${ }^{95}$ CRIMINAl LAWS, supra note 92; Vigil, REPORT TO THE House, supra note 7, at 5 . At least one state, Michigan, repealed a prior forced marriage criminal statute (former МiсH. СомP. LAWS. $\$ 750.11$ (repealed 2010)) as part of an effort to repeal outdated criminal statutes that were not being enforced. Id.

${ }^{96}$ Bangura et al., supra note 3, at 2; STOBART, supra note 86, at 13.

97 A WRONG NOT A RIGHT, supra note 16, at 2.1, 2.8 (reporting that in nearly all of the 250 cases per year addressed by the Home Office Forced Marriage Unit and in all of the 165 forced marriage cases reported to the Metropolitan police in the two years preceding the report, the potential victim sought assurances that no prosecution would result before accepting assistance). VIGIL, REPORT TO THE HouSE, supra note 7, at 8; Bangura et al., supra note 3 , at 12 .

98 Vigil, REPORT TO THE House, supra note 7, at 8. In the related context of female genital cutting, another form of violence perpetrated against young women and girls by family members, more than twenty years passed between the enactment of the federal law criminalizing the practice in 1996 and the first prosecution to enforce it. These first charges for female genital cutting were filed in April 2017 against a doctor, not parents or family members of the victim. Arlene Tchekmedyian, For the First Time in the U.S., a Doctor Is Charged 
crimes. ${ }^{99}$ These factors limit the viability of prosecution as a remedy after a forced marriage or an attempt to force a marriage has occurred, and the absence of forced marriage prosecutions prevents the criminal justice system from deterring the practice. ${ }^{100}$

Some may consider the child abuse and neglect system a preferable means of intervention for minors being forced into marriages by their parents. The system has been effective in preventing forced marriages in cases brought to its attention by experienced advocates. ${ }^{101}$ But, the abuse and neglect system may not be well-equipped to address the problem as a matter of course. In practice, child protection agencies may be unprepared to respond to forced marriage complaints, and may view the circumstances of a child's marriage as a "cultural dispute" rather than a case of abuse or neglect requiring state intervention. ${ }^{102}$

In some states, child protection orders provide a mechanism for individuals (rather than the state child welfare agency) to seek injunctive relief to protect a child. ${ }^{103}$ Petitions for child protection orders typically must be filed by designated adults on behalf of a child, and must allege that qualifying criminal conduct has occurred. ${ }^{104}$ Child protection orders typically offer a more limited range of remedies than those available through civil protection orders.

with Female Genital Mutilation. Here's How the Law Came to Be, L.A. Times, (Apr. 18, 2017), http://www.latimes .com/nation/la-na-female-genital-mutilation-detroit-2017-sto ry.html [https://perma.cc/TTM7-33ZQ].

99 These challenges also have undermined criminal prosecution as an effective response to forced marriage in United Kingdom. Since the United Kingdom criminalized forced marriage in 2014 , only one case reportedly has been prosecuted. The case is an outlier in many ways, including that it was brought against the intended spouse (not parents or relatives) of the victim, and the alleged conduct involved allegations of numerous acts of physical and sexual violence. Businessman Is First Person Jailed Under Forced Marriage Laws, GUARDIAN (June 10，2015， 10:17AM)， https://www.theguardian.com/society/2015/ jun/10/34-year-old-man-first-person-to-be-convicted-under-forced-marriage-laws [https://per ma.cc/WGA7-ULU8].

100 See Global Estimates of Modern Slavery, supra note 94, at 49.

${ }^{101}$ In Virginia, for example, remedies ordered through a child in need of supervision proceeding, including a child protection order and the appointment of a guardian ad litem enabled a minor to remain in her family home while also being protected from a forced marriage. Interview with Jeanne Smoot, Senior Policy Attorney, Tahirih Just. Ctr. (July 2017). ${ }^{102}$ Id.

103 Ala. Code § 12-15-138 (2017); Ariz. Rev. Stat. Ann. § 8-234 (2017); Colo. Rev. STAT. § 19-1-114 (2018); IDAHO CODE § 16-1619 (2017); 705 ILl. CoMP. STAT. 405/2-25 (2018); Ind. Code § 31-34-2.3-1 (2017); LA. ChILD. CodE AnN. art. 618 (2018); Me. STAT. tit. 22, § 4035 (2017); Mo. Rev. Stat. § 455.505 (2017); Mont. Code AnN. § 41-3-427 (2017); Nev. Rev. Stat. § 33.400 (2017); N.H. Rev. Stat. AnN. § 169-C:19 (2017); N.J. Stat. AnN. § 9:6-8.55 (West 2017); N.Y. FAM. CT. LAW § 1056 (McKinney 2018); OKLA. STAT. tit. 22, §60.19 (2017); S.D. CodifIEd LAws § 26-7A-107 (2017); TENN. CodE ANN. $\S 37-1-152$ (2017); UtAH CODE ANN. § 78B-7-202 (West 2017); VA. CODE ANN. § 16.1-253 (2017); Wis. STAT. § 48.45 (2017); WYo. STAT. ANN. § 14-3-430 (2017).

${ }^{104}$ See infra Section II.C.2. 
A separate, shared potential drawback of criminal, abuse and neglect, and child protection order proceedings for those facing forced marriages is the lack of control such individuals have over these processes. Criminal and child abuse proceedings are initiated and directed by the state, and child protection order proceedings are initiated and directed by the state or a designated adult on behalf of a minor child. Exercising control over how a case is presented and the remedies sought may be critical to the willingness of adults and older minors to seek legal relief. ${ }^{105}$ Such autonomy may be especially important to individuals who want to remain closely connected to their families or protect family members from embarrassment or other potentially negative repercussions from the case.

Tort law may be pointed to as a potential avenue for legal relief that provides an opportunity for an individual facing a forced marriage to exercise control over the legal proceeding. ${ }^{106}$ Although tort may provide a promising source of compensation for individuals harmed by forced marriage, and can also provide a path to an injunction-a civil court order that compels a defendant to respect a victim's rights by directing the defendant to take or avoid specific action. ${ }^{107}$ Nevertheless, several procedural hurdles undermine the viability of tort claims as a preventive tool. ${ }^{108}$ First, minor children are prohibited from bring-

${ }^{105}$ Recognizing that the need to involve an adult might deter minors from seeking assistance, many states have granted teenagers the authority to make autonomous decisions about issues relating to their health, well-being, and safety. Lisa Vollendorf Martin, What's Love Got to Do with It: Securing Access to Justice for Teens, 61 CATH. U. L. REV. 457, 503-05 (2012) (matters over which states have granted minors decision-making power include treatment for emergency medical care, substance abuse, sexually transmitted illnesses, mental health services, reproductive health services). Several states have likewise authorized minors to seek civil protection orders to protect themselves from dating and domestic violence without adult involvement. See infra Section II.C.3.b.

106 Douglas D. Scherer, Tort Remedies for Victims of Domestic Abuse, 43 S.C. L. REv. 543, 564-65 (1992) (noting that tort claims enable an individual to exercise control over the proceeding). Tort claims compensate individuals for wrongs done to them by other persons. Tort, BLACK's LaW DictionaRY (10th ed. 2014).

107 Tamara L. Kuennen, “No-Drop" Civil Protection Orders: Exploring the Bounds of Judicial Intervention in the Lives of Domestic Violence Victims, 16 UCLA WOMEN's L.J. 39, 5455 (2007).

${ }^{108}$ A plaintiff can request the court to enter an injunction under its powers of equity as part of its exercise of jurisdiction over a tort claim. When evaluating a claim for an equitable injunction in a tort case, courts must consider:

(1) the nature of the interest to be protected, (2) the relative adequacy to the plaintiff of the injunction and other remedies, (3) any unreasonable delay by the plaintiff in bringing suit, (4) any related misconduct on the part of the plaintiff, (5) the relative hardship likely to result to defendant if injunction is granted and to plaintiff if denied, (6) the interests of third persons and the public, (7) the practicality of framing and enforcing the judgment.

Jeffrey R. Baker, The Failure and Promise of Common Law Equity in Domestic Abuse Cases, 58 LOY. L. Rev. 559, 579-80 (2012) (citing the RESTATEMENT (SECOND) OF TORTS $§ 936$ (2011)). To support the issuance of a temporary injunction during the pendency of the case, the plaintiff further must establish "(1) the extent of the threat of irreparable harm to the plaintiff if the interlocutory injunction is not granted, (2) the consequences that the interlocu- 
ing tort cases against their parents in many states. ${ }^{109}$ Second, tort claims compensate retroactively; they may be brought only after harm/damages have been caused. ${ }^{110}$ This means that, even when a parent or another person attempting to force a marriage would be a permissible party in a tort case, a tort remedy for forced marriage only would be available after that individual takes action that actually causes harm to the plaintiff. Tort remedies would not be available to prevent a forced marriage or a related harm from occurring. Third, tort actions have a lengthy timeline for the issuance of relief, and do not provide a means to access immediate intervention. ${ }^{111}$ Fourth, those facing forced marriages may lack access to funds to cover the filing fees and costs that typically attend civil actions. ${ }^{112}$ Fifth, the process of seeking injunctive and compensatory relief through a tort action is complex and challenging to navigate without the assistance of counsel. ${ }^{113}$ Finally, equitable injunctions issued within tort cases lack a ready enforcement mechanism. Violations are actionable as civil contempt,

tory relief may have on the defendant, (3) the probability that the plaintiff will succeed on the merits, and (4) the public interest." Id. at 580.

109 The doctrine of parental immunity protects parents against tort claims arising out of conduct during a child's minority that is "inherent to the parent-child relationship." Elizabeth G. Porter, Tort Liability in the Age of the Helicopter Parent, 64 ALA. L. REV. 533, 545 (2013). As of 2013, more than half of states continued to recognize this doctrine. Id. The doctrine is intended to protect the privacy and harmony of the family. Id. at 539-53. These principles were likewise cited to justify the development of the doctrine of spousal immunity, which persisted well into the twentieth century, and was abrogated in light of the growing recognition that the sanctification of privacy facilitated male domination and abuse of women. Id. at 549; Reva B. Siegel, "The Rule of Love”: Wife Beating as Prerogative and Privacy, 105 YALE L.J. 2117, 2161-70 (1996).

${ }^{110}$ Baker, supra note 108, at 591.

${ }^{111} I d$. at 588-89 ("If the need for relief is immediate, urgent, and not monetarily quantifiable, tort actions are inadequate legal remedies; tort liability does not answer the victim's needs."); Jane K. Stoever, Enjoining Abuse: The Case for Indefinite Domestic Violence Protection Orders, 67 VAND. L. REv. 1015, 1063 (2014). By the time many individuals facing forced marriages reach out for help, they need immediate intervention and support. Swegman, Forced Child Marriage Case Scenarios for Lisa Martin, supra note 58. Emergency relief may be particularly important to prevent an individual from being taken abroad to marry because once an individual leaves the U.S., it becomes extraordinarily difficult for the government to intervene. Individuals taken abroad may have their passports taken from them, and may be physically isolated and cut off from outside communication. Consular officials may face significant challenges even locating and communicating with such persons, let alone assisting them to return to the United States. Individuals seeking to stave off international travel or an impending ceremony may need same-day court intervention and temporary ex parte relief. STOBART, supra note 86, at 14 .

112 Stoever, supra note 111, at 1063.

113 Cf. Nina W. Tarr, Civil Orders for Protection: Freedom or Entrapment?, 11 WASH. U. J.L. \& POL'Y 157, 161-63 (2003) (describing the time and procedural complexities inherent in seeking a civil injunction through a divorce claim, the most common mechanism for victims of domestic abuse to secure injunctive relief before the creation of the civil protection order remedy). 
which may amount to a "verbal 'slap on the hand," " or alternatively, could result in fines and even periods of jail time as a means to coerce compliance. ${ }^{114}$

Together, these gaps and the limited insight we have into the wishes of individuals facing forced marriage suggest that ready access to a low-barrier, emergency civil injunctive remedy could meaningfully benefit this group.

\section{The Viability of Civil Protection ORders to Prevent ForCed MARRIAGE}

\section{A. The History and Goals of Civil Protection Orders}

In the domestic violence context, similar challenges in securing effective, accessible legal relief led to the establishment of the civil protection order remedy in all fifty states and the District of Columbia. ${ }^{115}$ A product of the battered women's movement of the 1960s and 70s, civil protection orders were created to prevent future abuse and enhance the autonomy of those subjected to domestic violence. ${ }^{116}$ Over time, many states have expanded the context in which individuals can seek civil protection orders from domestic violence between spouses, family, and household members, to dating violence, stalking, and sexual assault. Some states have integrated these additional bases for relief into their original domestic violence civil protection order statutes, whereas others have created separate protection orders for these expanded contexts. ${ }^{117}$

Protection orders were revolutionary in enabling individuals subjected to domestic violence to reliably and expediently access the courts and secure enforceable legal relief tailored to their needs outside of divorce proceedings and criminal prosecutions. ${ }^{118}$ This enabled those subjected to abuse to seek legal protection without having to end their marriages or cooperate in seeking criminal penalties for those abusing them. ${ }^{119}$ Conversely, as law enforcement in the

${ }^{114}$ Id.; David J. Harmer, Limiting Incarceration for Civil Contempt in Child Custody Cases, 4 B.Y.U. J. PUB. L. 239, 243-44 (1990) (explaining that courts have inherent authority to hold parties in contempt for failure to comply with court orders). Punishments issued under a court's civil contempt power are remedial-for the benefit of the party that the order protects. Id. at $247-48$.

115 Every state and the District of Columbia enacted a protection order statute between 1970 and 1993. Catherine F. Klein \& Leslye E. Orloff, Providing Legal Protection for Battered Women: An Analysis of State Statutes and Case Law, 21 HofSTRA L. Rev. 801, 810 (1993).

${ }^{116}$ Barbara J. Hart, Civil Protection Orders, 43 Juv. \& FAM. CT. J. 5, 23 (1992); Klein \& Orloff, supra note 115 , at 810 .

117 Compare D.C. CODE $§ 16-1001$ (2018), with FLA. STAT. $\$ 741.28$ (domestic violence injunction), 784.0485 (2017) (stalking injunction), 784.046 (2017) (dating and sexual violence injunction) (2017).

118 Lisa A. GoOdman \& Deborah Epstein, Listening to Battered Women: A SurvivorCentered Approach to Advocacy, Mental Health, And Justice 79 (2008); Hart, supra note 116, at 23; Stoever, supra note 111, at 1040-43; Tarr, supra note 113, at 161-63.

119 Divorce was not a sure path to relief even for those who wanted to pursue it, and receiving injunctive relief as part of a divorce judgment was also not guaranteed. LEIGH 
1970s and 80s rarely arrested or prosecuted perpetrators of domestic violence even in cases where prosecution was strongly desired, the advent of protection orders created a viable path to legal intervention. ${ }^{120} \mathrm{~A}$ number of features have made protection orders a comparatively accessible civil remedy, including: the availability of same-day emergency ex parte relief, expedited proceedings, the elimination of fees for filing and service of process, the creation of simplified court forms, and the common availability of courthouse-based advocates to assist with the filing process. ${ }^{121}$ Where advocates are present, protection order proceedings also may serve as a gateway connecting those subjected to abuse to additional community social services resources. ${ }^{122}$ To enhance their deterrent effect, states imbued protection orders with stronger enforcement mechanisms than those associated with other civil injunctions, with many states making violation of a protection order a criminal offense as well as cause for criminal or civil contempt. ${ }^{123}$ To this end, civil protection orders offer an additional avenue

Goodmark, A Troubled Marriage: Domestic Violence and the Legal System 9 (2012); Tarr, supra note 113, at 163. But cf. GOODMAN \& EPSTEIN, supra note 118, at 5 (noting that system actors frequently encourage or coerce those subjected to domestic violence to leave their relationships, and this pressure deters women from seeking help from social services providers and the criminal justice system). Tort claims against abusive partners were often not available against spouses at this time because of the continued existence of the doctrine of spousal immunity, which has since been abrogated. See Baker, supra note 108, at 602-03. For a number of reasons, many who are subjected to abuse do not want their partners to go to jail and may find the relief offered by protection orders more beneficial to them or their children than prosecution. Sally F. Goldfarb, Reconceiving Civil Protection Orders for Domestic Violence: Can Law Help End the Abuse without Ending the Relationship?, 29 CARDOZO L. REV. 1487, 1508 (2008).

${ }^{120}$ GOODMAN \& EPSTEIN, supra note 118, at 71-73; GOODMARK, supra note 119, at 9.

${ }^{121}$ Goldfarb, supra note 119, at 1506; Tarr, supra note 113, at 163-65. Several common features of protection orders across states, including the elimination of filing fees and provision of cost-free assistance with service of process, have resulted from conditions upon federal funding instituted through the Violence Against Women Act of 1994 and its subsequent reauthorizations. See, e.g., Costs for Criminal Charges and Protection Orders, 34 U.S.C. $\S 10450$ (2012); Sarah Henry \& Monica N. Player, VAWA Prohibition on Fees for Service of Protection Orders: Implications for Law Enforcement Agencies, NAT'L CTR. ON PROT. ORDERS AND FULL FAITH \& CREDIT (2013), http://www.bwjp.org/assets/documents/pdfs/va

wa_prohibition_on_fees_for_service_of_protection_orders.pdf [https://perma.cc/2NXZ3SK4]. Accessing the remedy still poses challenges to self-represented parties as court forms can be complex, a contested evidentiary hearing may be required to secure relief. Goldfarb, supra note 119, at 1515-16 (the process of obtaining an order can be "difficult, confusing, and time-consuming," as well as "upsetting, intimidating, or embarrassing" for petitioners, and is more likely to be successful if petitioners have counsel or are supported by advocates and other system actors); Tarr, supra note 113, at 163-65.

${ }^{122}$ Goldfarb, supra note 119 , at 1509.

${ }^{123}$ Id. at 1516-17; Hart, supra note 116, at 20-21. 
into the criminal justice system for those who want to hold their abusers criminally accountable for continued abuse. ${ }^{124}$

Civil protection orders are not a panacea, and may have unexpected negative consequences. For example, mandatory arrest and "no drop" policies may result in criminal prosecution of respondents for protection order violations against petitioners' wishes, ${ }^{125}$ and court findings of protection order violations can result in deportation for non-citizen respondents. ${ }^{126}$ Moreover, petitioners who obtain protection orders may face discrimination in housing, insurance, and employment. ${ }^{127}$ Despite these potential drawbacks, protection orders have become the most widely used civil or criminal remedy to combat domestic violence in the United States and petitioners who obtain orders express a consistently high level of satisfaction with the remedy. ${ }^{128}$ Protection orders have proved effective at eliminating or decreasing violence and increasing petitioners' feelings of safety and autonomy. ${ }^{129}$

\section{B. The Potential for Civil Protection Orders to Prevent Forced Marriage}

Forced marriage is a different problem from domestic violence, and requires its own nuanced solutions. Yet, the problems share characteristics that suggest that civil protection orders may be an effective tool to prevent forced marriage. First, the comparative control exercised by petitioners in civil protection order proceedings over whether and how to pursue a case, the remedies sought, and whether and how to enforce court orders may encourage those facing forced marriages to seek relief. ${ }^{130}$ Second, those facing forced marriage may

${ }^{124}$ Stoever, supra note 111, at 1043. But see GOODMAN \& EPSTEIN, supra note 118, at 80 (noting that problems remain with police willingness to take action in response to complaints of protection order violations).

${ }_{125}$ Tarr, supra note 113, at 191-92.

1268 U.S.C. $\$ 1227(\mathrm{a})(2)(\mathrm{E})(\mathrm{ii})$ (2012); Cecelia M. Espenoza, No Relief for the Weary: VAWA Relief Denied for Battered Immigrants Lost in the Intersections, 83 MARQ. L. REV. 163, 180-81 (1999); GoODMAN \& EPSTEIN, supra note 118, at 77. See generally Hannah R. Shapiro, Battered Immigrant Women Caught in the Intersection of U.S. Criminal and Immigration Laws: Consequences and Remedies, 16 TEMP. INT'L \& COMP. L.J. 27, 27 (2002).

127 See GoOdman \& EPSTEIN, supra note 118, at 130-31.

${ }_{128}$ Goldfarb, supra note 119, at 1510; Stoever, supra note 111, at 1020-21.

129 Stoever, supra note 111, at 1021, 1064-66. But cf. Goldfarb, supra note 119, at 1511-14, 1516 (noting that studies of compliance with protection orders have been somewhat mixed, with compliance seeming to turn, in part, on the petitioner's feelings about ending the relationship, characteristics of the respondent, and the history of abuse within the relationship, as well as with a weak criminal justice system response to violations).

${ }^{130}$ This control over how a case is presented to the court, of course, does not equate to full control over the case result. For example, courts have denied petitioners' requests to vacate protection orders, keeping the orders in place over petitioners' objections and fined or imprisoned petitioners who initiate contact with respondents while an order is in place. GOODMAN \& EPSTEIN, supra note 118, at 81. See generally Kuennen, supra note 107, at 5455. 
need emergency intervention and expedited proceedings to bring some peace and stability into households and ongoing relationships. Third, those facing forced marriages who are financially dependent upon those they seek to restrain may be unable to retain counsel or afford filing fees and costs of litigation. ${ }^{131}$ Finally, given the stakes involved, and the possibility that perpetrators may feel entitled by cultural notions of honor or familial role to persist with their behavior, a civil remedy to prevent forced marriage may benefit from a strong, multifaceted enforcement regime. ${ }^{132}$

\section{The Fit of Civil Protection Orders to the Problem of Forced Marriage}

Although eligibility to seek a protection order varies by state, protection order statutes throughout the United States share a number of common features. ${ }^{133}$ To qualify for relief, a petitioner typically must share a particular relationship to the perpetrator and have been subjected to, or threatened with, particular conduct. ${ }^{134}$ The two prongs of this analysis merge in the many states permitting the issuance of protection orders on the basis of sexual assault and stalking regardless of the identity of the perpetrator. ${ }^{135}$ Notably, a minor's ability to access protection orders varies widely across states. ${ }^{136}$ Each of these features of the protection order remedy potentially limit its viability in the forced marriage context.

Potential petitioners seeking protection orders relating to forced marriage can be loosely grouped in three categories: (1) those seeking to prevent an impending marriage before it occurs, (2) those who were forced into a marriage against their consent and now seek protection and/or to escape, and (3) those who married consensually, but now feel forced to remain married and seek to escape ${ }^{137}$ Protection orders are available to varying extents to individuals in each of these groups. Civil protection orders are most likely to provide a viable remedy to prevent a forced marriage where a petitioner is an adult, is seeking to restrain a parent, relative, or household member, and has been subjected to or threatened with physical violence. After a forced marriage occurs, as well as when a person feels forced to remain in a marriage s/he entered consensually, protection orders are most viable if the petitioner seeks to restrain her spouse or seeks to protect herself from acts or threats of violence by parents or relatives.

\footnotetext{
131 See supra InTRODUCTION.

132 See supra INTRODUCTION.

133 Stoever, supra note 111 , at 1043.

134 See generally Klein \& Orloff, supra note 115, at 814-42, 848.

135 See infra Section II.C.2.c.ii.

136 See generally Martin, supra note 105, at 503.

137 See generally supra Section I.B.
} 


\section{Qualifying Relationships}

To establish standing to seek a protection order, a petitioner typically must first establish that she shares a qualifying relationship with the respondent. ${ }^{138}$ Protection order laws in many states have evolved from applying only to spouses and household members, to offering protection within other intimate relationships, and against perpetrators of rape and stalking, regardless of the relationship between the parties. ${ }^{139}$ Under the relationship requirement, whether a petitioner can seek a protection order to prevent a forced marriage turns on the identity of those attempting to coerce her. As the factual context of forced marriages differ from case to case, petitioners in forced marriage cases may need to pursue relief against a variety of actors.

\section{a. Parents}

In many forced marriage cases, parents play a central role in coercing the union. ${ }^{140}$ Most states permit the entry of domestic violence protection orders between children and parents. ${ }^{141}$ Some of these expressly provide protection between parents and children, whereas others protect blood relatives and/or current and former household members-groups that often include parents and children. ${ }^{142}$ Some states limit the remedy to children and parents who share or have shared a residence, whereas others prohibit minor children from obtaining protection orders against parents with whom they reside. ${ }^{143} \mathrm{~A}$ handful of states do not allow minor children to pursue domestic violence protection orders against parents. ${ }^{144}$ In these states, minor children must seek relief from their

${ }^{138}$ Professor Deborah Epstein first introduced me to the terms "qualifying relationship" and "qualifying conduct" to describe the common elements a petitioner must prove to justify the entry of a civil protection order. Deborah Epstein et al., Domestic Relations: Domestic Violence, in District of Columbia Practice Manual (2016).

${ }^{139}$ Hart, supra note 116, at 5; Martin, supra note 105, at 493; Stoever, supra note 111, at 1043-45.

${ }^{140}$ Swegman, Forced Child Marriage Case Scenarios for Lisa Martin, supra note 58.

141 See infra APPENDIX 1.

142 See infra APPENDIX 1.

143 Compare Ala. Code $\S 30-5-2$ (2017), Fla. Stat. $\$ 741.28$ (2017), Iowa Code $§ 236.2$ (2017), Kan. Stat. AnN. § 60-3102 (2017), Miss. Code AnN. § 93-21-3 (2017), and VT. STAT. AnN. tit. 15, §§ 1101, 1103 (2017), with N.H. Rev. STAT. AnN. § 173-B:1 (2017). The District of Columbia explicitly precludes custodial parents from seeking protection orders against minor children. Instead, these parents must seek court assistance through the Persons In Need of Supervision (PINS) program in the juvenile court. D.C. CODE $§ 16-1003$ (a)(6) (2018).

${ }^{144}$ IOWA CODE $§ 236.2$ (2017); Mich. CoMP. LAwS $§ 600.2950(27)(b)$ (2018); N.H. Rev. STAT. ANN. § 173-B:1 (2017) (prohibits minor children from seeking relief against parents with whom they reside); N.J. STAT. AnN. § 2C:25-19 (West 2017); OR. ReV. STAT. ANN. $\S 107.705$ (2018); UTAH CODE ANN. § 78B-7-102 (West 2017) (if petitioner is a minor); Wis. STAT. \$ 813.12 (2017); D.M.H. ex rel. Hefel v. Thompson, 577 N.W.2d 643, 646 (Iowa 1998) (holding that Iowa's protection order statute grants minors standing only to seek pro- 
parents through the child abuse and neglect system, or by seeking a child protection order. ${ }^{145}$

\section{b. Family and Household Members}

Those facing forced marriages might also experience coercion from other relatives, family friends, or community members. Most states permit the entry of domestic violence protection orders against additional relatives by blood or marriage.$^{146} \mathrm{~A}$ few states require that such relatives share a household to qualify for relief. ${ }^{147}$ The majority of states also permit the entry of protection orders against any household members, regardless of the nature of their relationships to the petitioner. ${ }^{148}$ Several states limit eligible household members to those who share an intimate or familial relationship with the petitioner. ${ }^{149}$

tection against spouses and individuals with whom they are cohabiting and precludes standing to seek protection against parents and other household members); M.A. v. E.A., 909 A.2d 1168, 1171 (N.J. Super. Ct. App. Div. 2006) (precluding a mother from bringing a claim on behalf of her minor daughter against the child's stepfather because the statute permitted only persons over eighteen or emancipated minors to bring claims against household members); Strother v. Strother, 34 P.3d 736, 737 (Or. Ct. App. 2001) (overturning a protection order sought by a mother on behalf of her minor child against the child's father because the statute did not offer protection to minors against parents); see also APPENDIX 4.

${ }^{145}$ State of N.H. Judicial Branch Family Div. \& Dist. Court, Domestic Violence PROTOCOLS 5 (2013). In Wyoming, child protection orders are available only as part of the final disposition of a child abuse and neglect case. WYO. STAT. ANN. § 14-3-430 (2017); see also supra Section I.G.

${ }^{146}$ See infra APPENDIX 1. Some states permit a broad range of relatives to seek relief, whereas others designate only certain relationships, such as siblings, or grandparents/grandchildren. Compare ALASKA STAT. § 18.66 .990 (2017) (related up to the fourth degree of consanguinity), D.C. CODE $\S 16-1001$ (2018) (relatives by blood, adoption, legal custody, marriage, or domestic partnership), and 15 R.I. GEN. LAWS § 15-15-1 (2017) (persons related by blood or marriage), with DEL. CODE ANN. tit. 10, §§ 901(12), 1041(2) (2017) (grandparents, grandchildren, siblings), N.M. STAT. ANN. § 40-13-2 (2018) (grandparents and grandchildren), and VA. CODE ANN. § 16.1-228 (2017) (siblings, grandparents and grandchildren).

147 See, e.g., Ala. CODE $§ 30-5-2$ (2017) (relative of an individual who qualifies as a current or former "household member" if the relative also lived with the defendant); FLA. STAT. $\S 741.28$ (2017); IOWA CODE $§ 236.2$ (2017) (reside together or resided together within one year of the assault); Ky. Rev. Stat. AnN. § 403.720 (West 2018); ME. StAT. tit. 19A, § 4002 (2017); Miss. Code AnN. § 93-21-3 (2017); Mont. Code AnN. § 45-5-206 (2017); Оhiо Rev. Code AnN. § 3113.31 (West 2017); VA. Code AnN. § 16.1-228 (2017) (parents-in-law, children-in-law, or siblings-in-law covered only if cohabit).

148 See Alaska Stat. § 18.66.990 (2017); Ariz. Rev. Stat. AnN. § 13-3601(A)(4) (2017); Ark. Code AnN. § 9-15-103 (2017); Cal. Fam. Code §6211 (West 2018); Colo. Rev. Stat. § 13-14-101 (2018); ConN. Gen. Stat. § 46b-38a(2) (2017); D.C. CodE § 16-1001 (2018); Fla. Stat. § 741.28 (2017); Ga. Code AnN. § 19-13-1 (2017); Haw. Rev. STat. $\S 586-1$ (2017); IDAHO CODE $§ 39-6303$ (2017); 750 ILl. COMP. STAT. 60/214 (2018); IOWA CODE $\$ 236.2$ (2017); KAn. Stat. AnN. § 60-3102 (2017); Ky. Rev. STAT. AnN. § 403.720 (West 2018) (unrestricted only if the victim is a child); MASS. GEN. LAwS ch. 209A, $\S 1$ (2017); Mich. Comp. LaWs § 600.2950 (2018); MinN. STAT. § 518B.01 (2017); Miss. Code AnN. § 93-21-3 (2017); Mo. Rev. Stat. § 455.010 (2017); Neb. Rev. Stat. § 42-903 


\section{c. Intended Spouse}

In some cases, an intended spouse may play a role in attempting to force a marriage. ${ }^{150}$ Whether a potential victim of forced marriage could seek protection against an intended spouse turns on the nature of their relationship at the time the case is filed. Although all states offer protection order relief against spouses, ${ }^{151}$ and a solid majority extend relief against dating partners, ${ }^{152}$ only a minority of states offer explicit protection for engagement relationships. ${ }^{153}$ This distinction is important in the forced marriage context. To find that parties have a qualifying dating relationship, courts may have to consider factors such as the length of the relationship; ${ }^{154}$ the frequency of the parties' interaction; ${ }^{155}$ the par-

(2017); NeV. Rev. Stat. § 33.018 (2017); N.H. Rev. Stat. ANN. § 173-B:1 (2017); N.J. Stat. ANN. § 2C:25-19 (West 2017); N.C. Gen. Stat. § 50B-1 (2017); N.D. CENT. Code § 14-07.1-01 (2017); Ohio Rev. Code AnN. § 3113.31 (West 2017); OKLa. Stat. tit. 22, $\S 60.1$ (2017); Or. Rev. STAT. § 107.705 (2018); S.C. COdE ANN. § 20-4-20 (2017); TENN. Code AnN. § 36-3-601 (2017); Tex. FAM. CodE AnN. § 71.003 (West 2017); UtAH CodE AnN. § 78B-7-102 (West 2017); VT. StaT. AnN. tit. 15, §§ 1101 (2017), 1103 (2017); VA. CODE ANN. § 16.1-228 (2017); WASH. Rev. CODE $§ 26.50 .010$ (2017); W. VA. CODE $\$ 48-27-$ 204 (2017); Wis. STAT. § 813.12 (2017); WyO. STAT. ANN. § 35-21-102 (2017).

149 ALA. CODE $\$ 30-5-2$ (2017) (stating that a person must have had an intimate relationship with the defendant or be a relative of someone who did); Del. CODE ANN. tit. 10, § 1041 (2017) (stating that cohabitants must hold themselves out as a couple); HAW. REv. STAT. $\S 586-1$ (2017) (excludes those cohabiting "only by virtue of an economic or contractual affiliation.”); KY. REV. STAT. ANN. \$ 403.720 (West 2018) (member of an unmarried couple unless the victim is a child, then no restriction as to relationship); LA. STAT. ANN. § 46:2132 (2017) ("sexual or intimate relationship"); ME. STAT. tit. 19A, § 4002 (2017) ("related by consanguinity or affinity"); MONT. CODE ANN. § 45-5-206 (2017) (includes "other past or present family members of a household."); 23 PA. CONS. STAT. § 6102 (2018) (“persons living as spouses").

${ }^{150}$ McFarlane et al., supra note 25, at 708 .

151 See infra APPENDIX 1; see also Klein \& Orloff, supra note 115, at 814-15.

152 See infra APPENDIX 1.

153 ALA. CODE $§ 30-5-2(3)$ b. (2017) (“A dating relationship includes the period of engagement to be married.”); CAL. FAM. CODE § 6211 (2018); HAW. REV. STAT. § 586-1 (2017); 750 ILl. Comp. StAT. 60/214 (2018); MASS. Gen. LAWS ch. 209A, § 1 (2017). Protection orders could also be available against fiancés in North Dakota, which permits a protection order to be issued if the parties are deemed by the court to have a "sufficient relationship." N.D. CENT. CODE § 14-07.1-01 (2017); Id. § 14-07.1.02 (2017); OKLA. STAT. tit., 22, § 60.1 (2017); 15 R.I. GEN. LAWS $\S 15-15-1$ (2017) (note that R.I. extends protection to engagement or dating relationships only where one party is a minor).

154 See, e.g., ARIZ. Rev. StAT. AnN. § 13-3601(A)(4) (2017); ARk. CodE AnN. § 9-15-103 (2017); Del. Code ANN. § 10-1041 (2017); IDAHO CodE § 39-6303 (2017); IOWA CODE $\S 236.2$ (2017); Kan. Stat. ANN. § 60-3102 (2017); Ky. Rev. StAT. ANN. § 456.030 (West 2018); La. Stat. AnN. § 46:2132 (2017); Mass. Gen. LaWs ch. 209A, § 1 (2017); MinN. Stat. § 518B.01 (2017); Miss. Code AnN. § 93-21-3 (2017); N.J. StAT. AnN. § 2C:25-19 (West 2017); N.Y. FAM. CT. LAW $\$ 812$ (McKinney 2018); N.C. GEN. STAT. § 50B-1 (2017); S.D. Codified Laws $§ 25-10-3.1$ (2017); TeX. FAM. Code AnN. $\$ 71.003$ (West 2017); Utah Code AnN. § 78B-7-402 (West 2017); Vt. Stat. AnN. tit. 15, § 1101 (2017); Wash. REV. CODE $§ 26.50 .010$ (2017). 
ties' expectations about the romantic, affectionate, or sexual nature of the relationship; ${ }^{156}$ whether the parties have affirmed their relationship to others ${ }^{157}$ and attendance at social outings as a couple. ${ }^{158}$ Ordinary fraternization and casual social relationships do not give rise to grounds for relief. ${ }^{159}$

Statutes that extend protection within dating relationships could appear sufficient to extend protection to fiancées as well, since romantic love and courtship commonly precedes marriage in the United States. ${ }^{160}$ In the case of a forced marriage, however, protecting only dating partners and spouses leaves a gap, since the petitioner may have no relationship with an intended spouse, let alone an intimate one. In such circumstances, a potential forced marriage victim may have no relationship-based ground to seek protection against an intended spouse and may need to rely instead on conduct-based grounds for relief.

\section{d. Crime-Based Relationships}

A number of states also have established crime-based relationship grounds for protection orders. These provisions permit protection orders to be entered against any individual who subjects a petitioner to particular crimes.

155 See, e.g., Ariz. Rev. StAt. AnN. § 13-3601(A)(4) (2017); ARK. CodE AnN. § 9-15-103 (2017); Del. Code AnN. tit. 10, § 1041 (2017); Fla. Stat. § 784.046 (2017); IdAHo Code $\S 39-6303$ (2017); IOWA CODE $§ 236.2$ (2017); KAN. STAT. ANN. § 60-3102 (2017); Ky. ReV. STAT. AnN. § 456.030 (West 2018); LA. STAT. ANN. § 46:2132 (2017); MASs. GEN. LAWS ch. 209A, § 1 (2017); MinN. STAT. ANN. § 518B.01 (2017); Miss. CodE ANN. § 93-21-3 (2017); Neb. Rev. Stat. § 42-903 (2017); Nev. Rev. Stat. §33.018 (2017); N.J. Stat. AnN. $\S 2$ C:25-19 (West 2017); N.Y. FAM. CT. LAW $\$ 812$ (McKinney 2018); S.D. CodifIED LaWS $\S 25-10-3.1$ (2017); TEX. FAM. CODE ANN. $\$ 71.003$ (West 2017); UTAH CODE ANN. § 78B7-402 (West 2017); Vt. Stat. AnN. tit. 15, § 1101 (2017); WaSh. Rev. Code $\$ 26.50 .010$ (2017).

156 See, e.g., CAL. FAM. CODE $§ 6211$ (2018); Haw. Rev. Stat. § 586-1 (2017); IdAHO Code $\S 39-6303$ (2017); IOWA CODE $\$ 236.2$ (2017); KAn. Stat. ANN. § 60-3102 (2017); Ky. ReV. Stat. AnN. § 456.030 (West 2018); La. Stat. AnN. § 46:2132 (2017); Mass. Gen. LaWs ch. 209A, § 1 (2017); Miss. Code AnN. § 93-21-3 (2017); Neb. Rev. Stat. § 42-903 (2017); Nev. Rev. Stat. § 33.018 (2017); N.H. Rev. Stat. AnN. § 173-B:1 (2017); N.J. Stat. AnN. $\S 2$ C:25-19 (West 2017); OR. Rev. STAT. § 107.705 (2018); Id. § 107.726 (West 2017); UTAH CODE ANN. § 78B-7-402 (West 2017).

157 See, e.g., S.K. v. J.H., 43 A.3d 1248, 1250 (N.J. Super. Ct. App. Div. 2012).

158 See, e.g., KY. REV. STAT. ANN. § 456.010 (West 2018).

159 See, e.g., ARK. Code Ann. § 9-15-103 (2017); Del. Code Ann. tit. 10, § 1041 (2015); Fla. StAT. § 784.046 (2017); HAW. Rev. STAt. § 586-1 (2017); 750 ILl. Comp. STAT. 60/214 (2018); Iowa Code $§ 236.2$ (2017); Ky. Rev. STAT. AnN. $\$ 456.030$ (West 2018); Miss. Code AnN. § 93-21-3 (2017); Nev. Rev. Stat. § 33.018 (201); N.Y. FAM. Ct. LAW § 812 (McKinney 2018); N.C. Gen. Stat. § 50B-1 (2017); OKLa. Stat. tit. 22, § 60.1 (2017); Tenn. Code Ann. § 36-3-601 (2017); Tex. Fam. Code Ann. § 71.003 (West 2017); Utah CODE AnN. § 78B-7-402 (West 2017); W. VA. CODE $§ 48-27-204$ (2017).

${ }^{160}$ D'vera Cohn, Love and Marriage, PEw RES. CTR. (Feb. 13, 2013) (summarizing results of a Pew poll showing that Americans view love as a primary reason to marry). 


\section{i. $\quad$ Stalking}

Many states would permit a potential victim of forced marriage to seek a protection order against any perpetrator of stalking, regardless of her relationship to the perpetrator. ${ }^{161}$ Some of these states have granted victims of stalking or harassment access to domestic violence protection orders, ${ }^{162}$ whereas others created a separate stalking or harassment protection order remedy for this group. ${ }^{163} \mathrm{~A}$ few states only extend protection order relief to victims of stalking or harassment who share another qualifying relationship with the offender. ${ }^{164}$

Stalking protection orders might provide an alternative route to protection against forced marriage in circumstances where a domestic violence protection order is unavailable - for example, where minor children are prohibited from filing against parents or relatives, engagement relationships do not qualify, or stalking or harassment is not qualifying conduct. ${ }^{165}$ However, some states explicitly preclude this approach. ${ }^{166}$ Specific challenges raised by pursuing stalking orders in the context of forced marriage are further discussed in below.

\section{ii. Sexual Assault}

Forced marriages often result in rape. ${ }^{167}$ Those facing forced marriages who fear that their marriage will lead to rape may want legal protection to prevent that outcome. A number of states permit victims of sexual assault to seek civil protection orders against their assailants, regardless of the nature of their relationship. ${ }^{168}$ As with stalking, some states have granted victims of sexual assault access to domestic violence protection orders, whereas other states have created a separate protection order remedy for this group. ${ }^{169}$ Pursuing protec-

161 See infra APPENDIX 1.

162 See, e.g., D.C. CODE ANN. § 16-1001 (2018); IND. CODE § 34-26-5-2(a)(2) (2017); ME. STAT. tit. 19A, § 4005 (2017); Mo. Rev. STAT. § 455.020(1) (2017); Mont. CODE ANN. $\S$ 40-15-102(2)(a) (2017); N.M. STAT. ANN. § 40-13-2(D)(1) (2018); OKLA. STAT. tit. 22, § 60.2 (2017); TENN. CODE ANN. § 36-3-602(a) (2017).

163 See, e.g., Cal. Civ. Proc. Code § 527.6(a)-(b)(3) (West 2018); Md. Code Ann., Cts. \& Jud. Proc. § 3-1503(a)(7) (West 2018); Wyo. StAT. AnN. § 7-3-506 (2017).

164 See, e.g., Ala. CodE $§ 30-5-1$ (2018); Miss. Code AnN. $\$ 93-21-3$ (2017); N.Y. FAM. CT. LAW $\S 812$ (McKinney 2018).

165 See, e.g., OR. Rev. STAT. § 30.866 (2018); Wyo. STAT. AnN. §§ 35-21-102 (2017); Wyo. STAT. ANN. § 7-3-506 (2017).

166 See, e.g., Conn. Gen. Stat. § 46b-16a (2017); Md. Code Ann., Cts. \& Jud. Proc. § 31503 (West 2018) (restricting access to peace orders to individuals not eligible to seek domestic violence protection orders); Мich. COMP. LAWs $§ 600.2950$ (28)(b) (2018) (precluding minors from seeking protection orders against parents on grounds of stalking or sexual assault).

167 See supra INTRODUCTION.

168 See infra APPENDIX 1.

169 Compare D.C. Code $\S 16-1001$ (2018); Mo. Rev. StAT. $\S \S 455.010(1)(\mathrm{e}), 455.020(1)$ (2017); Mont. Code AnN. § 40-15-102(2)(a) (2017), with Fla. STAT. § 784.046 (2017); Ohio Rev. Code Ann. § 2903.214 (West 2017); OKLa. Stat. tit. 22, § 60.2(A) (2017). 
tion orders as sexual assault victims, in theory, could provide those facing forced marriages an alternative basis for relief. ${ }^{170}$ Most states define victims of sexual assault for protection order purposes as a person who already has been assaulted. ${ }^{171}$ In some states, a person facing a forced marriage theoretically could seek to establish that the efforts to force their marriage amount to an attempted or threatened rape. ${ }^{172}$ As discussed in Section I.C.2.b, in practice, individuals who have not been sexually assaulted at the time they seek a protection order may face a number of challenges to securing relief on this basis.

\section{Qualifying Conduct}

Civil protection order statutes were first created in tandem with policy reforms aimed at enhancing the law enforcement response to domestic violence and they remain rooted in criminal law. ${ }^{173}$ In addition to establishing a qualifying relationship with the respondent, a petitioner seeking a civil protection order must demonstrate that the respondent engaged in qualifying conduct. In most states, this requires a petitioner to prove that the respondent committed or threatened to commit one or more designated acts. Some states permit the issuance of a protection order upon proof that the respondent has committed any criminal offense against the petitioner. ${ }^{174}$ Others limit qualifying conduct to a defined list of acts - often criminal offenses. ${ }^{175}$ Still others take a hybrid ap-

${ }^{170}$ In a state like New Jersey, minor children are prohibited from seeking domestic violence protection orders against parents but permitted to seek sexual assault protection orders against any assailant, which could include parents. N.J. STAT. ANN. § 2C:14-14 (West 2017). This approach may be undercut by the statute's grant of standing to parents or guardians to file such petitions on behalf of minor victims of sexual assault, which could be read to prohibit minors from pursuing relief without the involvement of a parent or guardian. Id.; see also Martin, supra note 105, at 466. By contrast, Michigan and Oregon (two states that also preclude minors from seeking domestic violence protection orders against parents) explicitly prohibit minor children from obtaining sexual assault protection orders against adult family members. Mich. COMP. LAwS $§ 600.2950(27)(a)$ (2018); OR. REV. STAT. § 163.763(1)(b) (2018).

${ }^{171}$ See, e.g., 740 ILl. Comp. Stat. 22/103 (2018); InD. CoDE § 34-26-5-1(a)(2) (2017); Mich. Comp. Laws § 600.2950a (2018); Wyo. STAT. ANN. § 7-3-506 (2017).

${ }^{172}$ Mo. Rev. STAt. §\$ 455.010(1)(e), 455.020(1) (2017); N.J. Stat. AnN. § 2C:14-14 (West 2017); TENN. CODE ANN. \$ 36-3-601(7) (2017) (including any person who has been subjected to, threatened with, or placed in fear of any form of rape or sexual battery); VT. STAT. ANN. tit. 12, § 5133(a) (2017); WIS. STAT. § 813.125(1), (3) (2017).

173 GoOdMAN \& EPSTEIN, supra note 118, at 71-72; GoODMARK, supra note 119, at 9-10.

${ }^{174}$ In such states, it may be left to the courts to develop the contours. See, e.g., D.C. CoDE $\S 16-1003$ (2018) (requiring a petitioner to prove that a "criminal offense" has been committed against the petitioner's person); Murphy v. Okeke, 951 A.2d 783, 788 (D.C. 2008) (holding that unlawful entry may constitute a qualifying crime against a petitioner's person for purposes of the District's civil protection order statute if the circumstances indicate that the petitioner's physical safety was at risk).

175 See, e.g., Colo. Rev. Stat. § 13-14-101 (2018); 750 Ill. Comp. Stat. 60/103 (2018); Ky.Rev. Stat. AnN. § 403.720 (West 2018); Mass. Gen. Laws ch. 209A, § 1 (2017); NeV. REV.STAT. § 33.018 (2018). 
proach, listing both specific acts or offenses and unspecified "other criminal conduct" as sufficient to justify relief. ${ }^{176}$ Qualifying conduct can include not only completed acts, but also attempts to commit listed offenses, ${ }^{177}$ and aiding, abetting, or conspiring in the commission of a listed offense. ${ }^{178}$

Some states require not only a showing that particular conduct occurred, but also that it threated the petitioner's safety. ${ }^{179}$ Demonstrating the imminence of a threat to one's safety may pose a particular challenge to individuals who are deliberately deprived of information about marriage plans in order to reduce opportunities for resistance. ${ }^{180}$

My research identified only one state to date-Texas - that permits the issuance of a protection order upon a finding that a family or household member engaged in acts or omissions "forcing or coercing a child to enter into a marriage." ${ }^{181}$ In addition, the District of Columbia permits the issuance of a protection order upon a finding that a respondent committed any criminal offense against the petitioner, and the District criminalizes forced marriage, which means that a petitioner arguably could seek a protection order on the basis of a threatened forced marriage there. ${ }^{182}$ In most states, a petitioner seeking a protection order in the context of a forced marriage must allege that the respondent has committed another qualifying crime against her.

\section{a. Physical Violence}

Individuals subjected to acts and threats of violence have the clearest path to securing relief. All states designate crimes or acts of physical violence as qualifying conduct; ${ }^{183}$ most include threats of physical harm; $;{ }^{184}$ and a number

176 See infra APPENDIX 3.

177 See, e.g., Ala. Code $§ 30-5-2$ (2017); Alaska STAT. § 18.66.100(a) (2017); CAL. FAM. Code $\$ 6320$ (West 2018); Colo. Rev. STAT. § 13-14-101 (2018); Del. Code ANN. tit. 11, $\S 3906$ (2017); Ind. Code § 34-26-5-1 (2017); KAn. Stat. AnN. § 60-3102 (2017); ME. STAT. tit. 19-a, § 4002 (2017); MASS. GEN. LAwS ch. 209A, § 1 (2017); Miss. CODE ANN. § 93-21-3 (2017); Mo. ReV. STAT. § 455.010 (2017); Neb. Rev. Stat. § 42-903 (2017); N.H. Rev. Stat. AnN. § 173-B:1 (2017); N.C. Gen. Stat. § 50B-1 (2017); Ohio Rev. Code AnN. $\S 3113.31$ (West 2017); Or. Rev. STAT. § 107.705 (2018); 23 Pa CONS. STAT. § 6102 (2017); 15 R.I. GEN. LAwS § 15-15-1 (2017); S.D. Codified LAWS § 22-1-2(9) (2017); TENN. CODE ANN. § 36-3-601 (2017); UtAH Code ANN. § 77-36-1 (West 2017); Vt. STAT. AnN. tit. 15, $\S 1101$ (2017); W. VA. CODE § 48-27-202 (2017); Wyo. STAT. AnN. § 35-21-102 (2017).

178 See, e.g., S.D. CoDIFIED LAws $\S \S 22-1-2(9), 22-19 A-8$ (2017) (conspiracy to commit a listed felony crime can justify the issuance of a "crime of violence" protection order); UTAH CODE ANN. §77-36-1 (West 2017) (conspiracy or solicitation to commit a listed offense against a qualifying individual).

179 See, e.g., N.H. REV. STAT. ANN. § 173-B:1 (2017).

180 VIGIL, REPORT TO THE HOUSE, supra note 7 , at 8.

181 Tex. Fam. CodE. AnN. $\S \S 71.004,261.001(1)(\mathrm{M})$ (West 2017).

182 D.C. CODE $\$ \S 16-1005(\mathrm{c}), 22-2705$ (a)(3) (2018).

183 See infra APPENDIX 3.

184 See infra APPENDIX 3. 
include kidnapping, unlawful restraint, and false imprisonment. ${ }^{185}$ Minor petitioners seeking protection against their parents also may need to demonstrate that the parental conduct at issue did not amount to reasonable parental discipline. ${ }^{186}$

\section{b. Rape}

Petitioners seeking protection against a forced marriage might also seek to establish that the respondent is conspiring, attempting, or threatening to subject the petitioner to rape. Such petitioners might consider the attempt to force marriage itself as an attempt to force unwanted sex with the intended spouse. ${ }^{187}$ The law has long recognized sexual intimacy as a fundamental feature of the marital relationship. ${ }^{188}$ Historically, state codes authorized annulment upon proof of sexual incapacity, ${ }^{189}$ and criminalized sex outside of marriage through adultery and fornication offenses. ${ }^{190}$ Because of the centrality of sexual intercourse to

185 See infra APPENDIX 3.

186 See, e.g., Chronister ex rel. Morrison v. Brenneman, 742 A.2d 190, 193 (Pa. Super. Ct. 1999) (The court held that the father's actions of hitting the child with a belt across the rear only amounted to corporal punishment, not abuse, which is allowed for parental discipline); Beermann v. Beermann, 559 N.W.2d 868, 872-73 (S.D. 1997) (Father's use of force to keep his daughter in a sitting position was not abuse and was within reasonable parental discipline; however, the accompanying aggression and volatile language could make the action amount to actionable conduct); John P.W. ex rel. Adam W. v. Dawn D.O., 591 S.E.2d 260, 263, 265-66 (W. Va. 2003) (It is within the right of a parent to temporarily restrain their child for means of talking to them. The mother's actions of grabbing her son's arm fit within this definition and constitute reasonable parental discipline).

${ }^{187}$ See, e.g., Forced Marriage Initiative-Success Story-Stefanie, TAHIRIH JUST. CTR., http://preventforcedmarriage.org/success-stories-2/ [https://perma.cc/K6WD-Q9AJ] (describing story of "Stefanie," a thirteen-year-old American citizen who escaped from her father's home in Saudi Arabia as he was planning her marriage, noting that she was afraid of being raped by her potential husband and facing increasing psychological and physical abuse by her father and step-mother).

${ }^{188}$ Maynard v. Hill, 125 U.S. 190, 210 (1888) (Marriage "is an institution, in the maintenance of which in its purity the public is deeply interested, for it is the foundation of the family and of society, without which there would be neither civilization nor progress"); Obergefell v. Hodges, 135 S. Ct. 2584, 2599 (2015) ("The nature of marriage is that, through its enduring bond, two persons together can find other freedoms, such as expression, intimacy, and spirituality.").

189 See, e.g., N.C. GEN. STAT. § 51-3 (2017) (a marriage may be annulled "between persons either of whom is at the time physically impotent"); N.Y. DoM. REL. LAw § 140(d) (McKinney 2018) (action to annul a marriage on the ground that one of the parties was physically incapable of entering into the marriage state may be maintained); TEX. FAM. CODE ANN. $\S 6.106$ (West 2017) ("an annulment of a marriage [may be granted] if: (1) either party ... was permanently impotent at the time of the marriage. ...").

190 See, e.g., FLA. STAT. $\$ 798.01$ (2017) ("Whoever lives in an open state of adultery shall be guilty of a misdemeanor. ..."); 720 ILL. COMP. STAT. 5/11-40 (2018) ("Fornication is a Class B misdemeanor.”); MD. CoDE ANN., CRIM. LAW § 10-501(b) (West 2018) (“A person who [commits adultery] is guilty of a misdemeanor. ..."); MinN. STAT. § 609.34 (2017) ("When any man and single woman have sexual intercourse with each other, each is guilty of 
marriage, an attempt to force a marriage arguably could constitute an attempt to force sexual contact between the spouses. When an individual does not consent to a marriage, it can be inferred that she also would not consent to sex within that marriage. Thus, a petitioner potentially could argue that a third party's attempt to force her marriage constitutes an attempt to force the petitioner's rape within the marriage, or perhaps amounts to a threat of rape. ${ }^{191}$ The historical failure of the criminal justice system to respond to complaints of marital rape lends credence to fears that individuals forced into marriage may be unprotected from sexual violence. ${ }^{192}$

Courts have drawn an analogous connection between facilitating a marriage and facilitating sex in the context of underage marriages. In at least two cases, courts convicted parents who enabled their minor children to marry before the children reached the minimum marriage of child endangerment or contributing to the delinquency of a minor. ${ }^{193}$ Each conviction rested, in part, on the assumption that the marriage would result in the child engaging in sex with her spouse, despite that neither court appeared to have been presented with evidence of whether or not sexual relations actually had occurred within the marriage. ${ }^{194}$ These courts did not take up the issue of whether the parents' actions could amount to a conspiracy to commit rape. Indeed, the courts' analyses appear to assume that the sex acts occurring within the marriages would be con-

fornication, which is a misdemeanor.”); S.C. CODE ANN. § 16-15-60 (2017) (“[persons] guilty of the crime of adultery or fornication shall be liable to indictment and, on conviction, shall be severally punished. ...”). See generally Laurence Drew Borten, Sex, Procreation, and the State Interest in Marriage, 102 COLUM. L. REV. 1089, 1114 (2002).

${ }^{191}$ Commentators similarly have argued that state laws that permit parents to consent to the marriage of a minor under the age of consent essentially permit parents to consent to a minor's ongoing statutory rape. Erin K. Jackson, Addressing the Inconsistency Between Statutory Rape Laws and Underage Marriage: Abolishing Early Marriage and Removing the Spousal Exemption to Statutory Rape, 85 UMKC L. REV. 343, 345 (2017).

192 See generally Jill Elaine Hasday, Contest and Consent: A Legal History of Marital Rape, 88 CALIF. L. ReV. 1373, 1492 (2000).

193 People v. Benu, 385 N.Y.S.2d 222, 223 (N.Y. Crim. Ct. 1976); State v. Gans, 151 N.E.2d 709, 714-15 (Ohio 1958); see also Associated Press, Minors' Forced Marriages Lead to 3 Arrests, L.A. TIMES, (Nov. 20, 1996) (an Iraqi refugee was charged with child abuse and his wife was charged with contributing to the delinquency of a minor after allegedly forcing his thirteen and fourteen year-old daughters to marry men more than fifteen years older than they were; the husbands were charged with sexual assault of a child).

194 In State v. Gans, the court reasoned that the "propensity among young married couples to propagate," as well as the onerous duties of homemaking, were likely to lead to the minor daughter's truancy, and were she to remain in school, the mature "knowledge and attitudes" the minor daughter would gain as a result of her marriage would cause her to act in ways that would undermine the morals of her classmates. 151 N.E.2d at 714-15; see also Benu, 385 N.Y.S.2d at 227 (quoting Gans to suggest that the "mating instinct" will take over within a marriage even if the parties are under the statutorily prescribed ages and pointing to harms that could befall the minor as a result, including being treated as chattel in the marriage, truancy, and the creation of a "chasm" between her and her classmates should she remain in school). 
sensual. As a result, neither court considered the question of the child's consent nor the parent's intent regarding whether sexual contact would occur consensually. Nonetheless, the courts' holdings are significant because they equate a parent's facilitation of marriage with a parent's facilitation of sex between the spouses in that marriage, and find parents criminally responsible for exposing their children to harms that could result from that sexual conduct.

Although many states authorize protection orders on the basis of sexual assault only if an assault already has occurred, ${ }^{195}$ several states permit petitioners who have experienced attempted or threatened sexual offenses to seek protection as well. ${ }^{196}$ To find that the conduct of a third party other than the assailant (such as a parent or relative forcing a marriage) constituted an attempt or threat of rape, a court likely would have to find that the third party intended or knew that sexual contact would occur in the marriage, and that such contact would occur without the petitioner's consent. A respondent in such case could argue that he or she had no expectation that the marriage would result in rape, but rather that any sex would occur only with the petitioner's consent. Petitioners may have more success with this approach in a jurisdiction like Tennessee, which permits protection orders to be issued upon a finding that a petitioner "has been placed in fear of any form of rape," and thereby centers the court's inquiry on the petitioner's understanding of the respondent's conduct.

Alternatively, equating attempts to force marriage with attempted or threatened rape may have greater force when a child is legally incapable of consenting to sexual contact. Statutory rape laws establish an age before which minors are presumed unable to consent to sex, thereby criminalizing sex with all minors below that age, regardless of consent. ${ }^{197}$ Yet, state laws on marriage age complicate this argument. If a state approves a marriage involving a minor below that age of consent, the state ostensibly sanctions sexual relations between

195 See sources cited supra note 171.

196 See sources cited supra note 172.

197 See, e.g., ARK. CODE ANN. § 5-14-103(a)(3) (2017) (engaging in sexual intercourse with someone under age fourteen who is at least three years younger); GA. CODE ANN. § 16-6-3 (2017) (sexual intercourse with any person under the age of 16); Ky. ReV. Stat. AnN. $\S 510.020$ (West 2018) (sexual act with someone unable to consent. "A person is deemed incapable of consent when he or she is . . less than sixteen (16) years old...."); TENN. CODE ANN. § 39-13-506 (2017) ("Statutory rape is the unlawful sexual penetration of a victim by the defendant or of the defendant by the victim when: (1) The victim is at least thirteen (13) but less than fifteen (15) years of age and the defendant is at least four (4) years but less than ten (10) years older than the victim. ..."). See generally Rigel Oliveri, Note, Statutory Rape Law and Enforcement in the Wake of Welfare Reform, 52 STAN. L. REV. 463, 465 (2000); Asaph Glosser et al., Lewin Grp., Statutory Rape: A Guide to State Laws AND REPORTING REQUIREMENTS (2004) (fifty-state survey of statutory rape laws and requirements). 
the minor and his or her spouse. ${ }^{198} \mathrm{~A}$ few states expressly exempt sex between spouses from statutory rape offenses. ${ }^{199}$

Although the attempt to force a marriage could be argued to constitute a threat of rape for these reasons, my research has not identified a court that has made such a finding. Given the novel nature of the claim, it may be unlikely that a court would do so.

\section{c. Non (Physically) Violent Conduct}

Those facing forced marriages who experience non-physically violent means of coercion have a harder road to a remedy. The limited data on forced marriage in the United States suggests that those trying to force marriages often use emotional, psychological, and financial means of coercion, such as threatening to harm or kill themselves, isolation, social ostracization; declaring the ruin of a family's reputation; and threatening to withhold financial support, kick the individual out of the house, or have the individual deported. ${ }^{200} \mathrm{Al}-$ though these tactics exert significant power over potential victims, such conduct only will support the issuance of a protection order in most states if it constitutes a criminal offense. ${ }^{201}$

Individuals subjected to forms of coercion, other than the use or threat of physical violence, are ineligible for civil protection orders in a number of states. ${ }^{202}$ Petitioners in states with broader designations of qualifying conduct may be able to secure relief by demonstrating they suffered destruction of property, ${ }^{203}$ animal cruelty, ${ }^{204}$ purposeful isolation ${ }^{205}$ or other conduct that in-

${ }^{198}$ Erin K. Jackson, Addressing the Inconsistency Between Statutory Rape Laws and Underage Marriage: Abolishing Early Marriage and Removing the Spousal Exemption to Statutory Rape, 85 UMKC L. REV. 343, 361-62 (2017).

199 GLOSSER ET AL., supra note 197, at 10, stating:

In some states, marriage is a defense to all [statutory rape] crimes listed (e.g., Alaska, District of Columbia, West Virginia); other states exclude some of the more aggravated [statutory rape] offenses from this exemption (e.g., Arkansas, Louisiana, Mississippi). In a few states [e.g., South Carolina], the criminal [statutory rape] statutes identify age limits for the marriage exemptions.

${ }^{200}$ HeIMAN \& SMOOT, supra note 8, at 8-9.

${ }^{201}$ Legal scholars have explored how the restriction of the civil protection order remedy to criminal conduct likewise presents obstacles to legal relief for those subjected to psychological and economic forms of domestic violence. See GoODMARK, supra note 119, at 46; Margaret E. Johnson, Redefining Harm, Reimagining Remedies, and Reclaiming Domestic Violence Law, 42 U.C. DAVIS L. REV. 1107, 1111 (2009).

202 See, e.g., Ark. Code Ann. § 9-15-103 (2017); Conn. Gen. Stat. § 46b-15 (2017); IDAHO CODE § 39-6303 (2017); IOWA CODE § 236.2 (2017); Ky. Rev. STAT. ANN. § 403.720 (West 2018); Mass. Gen. Laws ch. 209A, § 1 (2017); N.D. Cent. CodE § 14-07.1-01 (2017); OKLA. Stat. tit. 22, § 60.1 (2017); Or. Rev. STAT. $\$ 107.705$ (2018); VA. Code ANN. $\S 19.2-152.9$ (2017).

${ }^{203}$ AlASKA STAT. $\$ 18.66 .100$ (a) (2017) (criminal mischief); CAL. FAM. CODE $§ 6301$ (West 2018), 6320 (West 2018) (destroying personal property); HAW. ReV. STAT. § 586-1 (2017) (malicious property damage); N.H. REv. STAT. ANN. § 173-B:1 (2017); N.J. STAT. ANN. $\S 2$ C:25-19 (West 2017) (criminal mischief); N.M. STAT. ANN. § 40-13-5 (2018); N.Y. FAM. 
terfered with their liberty or caused emotional distress. ${ }^{206}$ In most states, the most viable path to relief where only non-physical conduct has been used requires situating the petitioner's experiences within the criminal offenses of child endangerment or stalking and harassment. Each of these alternatives present challenges in the forced marriage context. A few states include coercion, restraint of liberty, or other forms of emotional or psychological abuse as qualifying conduct; yet even under these grounds petitioners sometimes must demonstrate a nexus to physical violence..$^{207}$

\section{i. Child Endangerment/Contributing to the Delinquency of a Minor}

A minor petitioner seeking protection against her parents could allege that their conduct amounts to child endangerment or contributes to the delinquency of a minor. ${ }^{208}$ In some states, a finding of child endangerment may require proof that a defendant willfully engaged in conduct likely to harm a child's physical, mental, and moral welfare. ${ }^{209}$ Under broader conceptions of child endangerment in some states, a defendant need not have a specific intent to injure the morals of the child. ${ }^{210}$ Rather, the defendant simply must undertake the relevant actions knowingly and not by accident. ${ }^{211}$ At least one court has upheld a parent's conviction for child endangerment after finding that a father "knowingly played an active part in the [marriage] ceremony" of his thirteen-year-old daughter to a seventeen-year-old boy. ${ }^{212}$

CT. LAW § 812 (McKinney 2018) (criminal mischief); TenN. CodE AnN. § 36-3-601 (2017); UtAH Code ANN. § 77-36-1 (West 2017); WIS. STAT. §§ 813.122 (2017), 48.02 (2017).

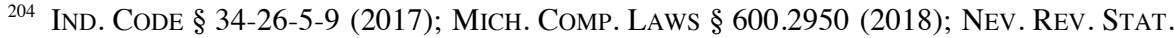
$\S 33.018$ (2017); N.H. Rev. Stat. AnN. § 173-B:1 (2017); TenN. CodE ANN. § 36-3-601 (2017).

${ }^{205}$ Mo.Rev. Stat. § 565.074.1(6) (2017) (“A person commits the crime of domestic assault in the third degree if the act involves a family or household member or an adult . . and ... (6) The person knowingly attempts to cause or causes the isolation of such family or household member by unreasonably and substantially restricting or limiting such family or household member's access to other persons. ...").

${ }^{206}$ See infra Section II.C.2.c.iii, iv.

207 Johnson, supra note 201, at 1133 (physical violence constitutes qualifying conduct in all states, coercion, restraint of liberty, or false imprisonment covered in only one third of states (most requiring a threat of physical harm), and psychological or emotional abuse covered in only one third of states).

208 See infra APPENDIX 3.

${ }^{209}$ People v. Benu, 385 N.Y.S.2d 222, 226 (N.Y. Crim. Ct. 1976).

${ }^{210} I d$.

${ }^{211} I d$.

${ }^{212} I d$. The court upheld the conviction in spite of its recognition that the father believed his actions were beneficial to the child, as he viewed her marriage as "a desirable alternative to fornication," which he feared would occur after his daughter expressed interest in the boy to her brother. 
Contributing to the delinquency of a minor generally requires conduct that causes or encourages a child to become delinquent, in need of services, or abused or neglected. ${ }^{213}$ Courts may be empowered to make a finding of "contributing" without finding that a minor actually was delinquent, since contributing statutes may encompass conduct that not only results in delinquency, but also that is likely or "tends" to do so. ${ }^{214}$

\section{ii. $\quad$ Stalking and Harassment}

In some states, a petitioner might be able to show that emotionally, psychologically, or financially coercive conduct amounts to stalking or criminal harassment. ${ }^{215}$ Criminal stalking and harassment offenses typically require proof that: (1) a perpetrator engaged in a course of conduct directed at the petitioner; (2) the conduct caused the victim to fear for her safety or to feel seriously alarmed, disturbed, or frightened; and (3) the perpetrator intended to make the victim feel that way, or should have known that his or her actions would have that result. ${ }^{216}$ Establishing that the conduct of an individual attempting to force a marriage constitutes stalking or harassment presents several significant challenges.

First, a petitioner must prove that a respondent acted with the requisite intent. Some states require proof that a respondent had a specific intent to harass; whereas others require intentional or knowing conduct, or the lack of a legitimate purpose ${ }^{217}$ Establishing specific intent may be particularly challenging in forced marriage cases involving a parent, which could require a petitioner to prove that the parent intended to harass or terrify the petitioner rather than to advance the petitioner's best interests (as the parent understood them). Likewise, a petitioner could be required to prove that the parent's attempts to coerce a marriage served no legitimate purpose. In such circumstances, a court might be required to identify the point at which a parent's potentially legitimate purpose (e.g. wanting to secure a child's future, or guide a child toward life deci-

213 See, e.g., OHIO REv. CODE ANN. § 2919.24 (West 2017).

${ }^{214}$ State v. Gans, 151 N.E.2d 709, 714 (Ohio 1958) (upholding parental convictions for contributing to the delinquency of a minor after the defendants instructed their eleven-year-old daughter to misrepresent her age to a county clerk and consented to the issuance of her marriage license, concluding that actively enabling a minor under the lawful age to marry tends to cause delinquency because her marriage was likely to cause her to become truant and endanger the morals of her classmates because of the "mature" knowledge and attitudes she will acquire as a spouse); see also Marriage or Rape?, NEWSWEEK (Dec. 15, 1996, 7:00 PM) (a mother was charged with contributing to the delinquency of a minor after her two thirteen and fourteen year-old daughters were allegedly forced to marry substantially older men; the father was charged with child abuse and the husbands were charged with rape).

215 See infra APPENDIX 3; see also GOODMARK, supra note 119, at 41.

${ }^{216}$ See generally Aaron H. Caplan, Free Speech and Civil Harassment Orders, 64 Hastings L. J. 781 (2013); Tracey B. Carter, Local, State, and Federal Responses to Stalking: Are Anti-Stalking Laws Effective?, 22 WM. \& MARY J. WOMEN \& L. 333, 351 (2016).

${ }^{217}$ Caplan, supra note 216, at 796. 
sions a parent believes beneficial) becomes illegitimate (e.g. forcing a marriage regardless of a child's wishes, or forcing a marriage to the detriment of a child's welfare).

Proving that a respondent's conduct had the requisite impact on the petitioner's own mental state presents a second significant challenge. Some states require a petitioner to prove that she actually feared for her safety or felt seriously alarmed, disturbed, or frightened; whereas others require a petitioner to show that a reasonable person in her circumstances could feel the same; and still other states require both. ${ }^{218}$ In theory, a petitioner could attempt to satisfy this requirement simply by showing that she believed the respondent aimed his or her conduct to force her into a marriage that she did not wish to enter. The petitioner could allege that her fear or alarm stemmed from the consequences of the potential union itself, or the consequences she would face by resisting the marriage. Some states presume that certain types of conduct, such as creating a disturbance at a petitioner's place of employment or school; repeatedly telephoning, following, or keeping a petitioner under surveillance; improperly concealing or threatening to remove the petitioner's minor child from the jurisdiction; or threatening physical force, confinement or restraint cause emotional distress. ${ }^{219}$ Petitioners also might be required to demonstrate that court action against particular tactics is constitutionally permitted. ${ }^{220}$ Respondents may argue that findings of stalking or harassment rooted in a respondent's speech may violate the free speech guarantees of the First Amendment. ${ }^{221}$

\section{iii. Criminal Coercion/Restraint of Liberty}

In a minority of states, a petitioner could seek a protection order on the basis that a respondent has wrongfully coerced or restricted her liberty. ${ }^{222}$ Professors Leigh Goodmark and Margaret Johnson have noted that although such provisions look beyond the direct infliction of physical violence, provisions often define the relevant conduct "by reference to actual or threatened physical force or violence. ${ }^{223}$ For example, to demonstrate that a respondent subjected her to coercion or an interference with personal liberty, a petitioner typically must prove that the respondent compelled the petitioner by force, threat of force, or intimidation "to engage in conduct from which [the petitioner] has the right or privilege to abstain, or to abstain from conduct in which [the petitioner]

${ }^{218}$ Id. at 795; Carter, supra note 216 , at 359.

219750 Ill. COMP. STAT. 60/103 (2018).

${ }^{220}$ Caplan, supra note 216, at 808-26; Carter, supra note 216, at 374-78; see also infra Section II.C.2.d.

${ }^{221}$ Carter, supra note 216, at 377.

222 Johnson, supra note 201, at 1133-34.

${ }^{223}$ GoOdMARK, supra note 119, at 38; see also Johnson, supra note 201, at 1133-34. 
has a right or privilege to engage." 224 Illinois further grants a cause of action to minor petitioners who allege that a caretaker forced them to "participate in or witness the physical abuse, confinement, or restraint of another," 225 and designates "knowing, repeated, and unnecessary sleep deprivation" as an actionable form of physical abuse. ${ }^{226}$

\section{iv. Emotional Abuse}

Several states also permit a petitioner to seek a protection order on the basis of emotionally abusive conduct not tied to physical violence (outside the realm of stalking or harassment). Actionable conduct varies by state, and includes the willful deprivation of necessities to a dependent, ${ }^{227}$ "interfering with [a] petitioner at petitioner's place of employment or education or engaging in conduct that impairs petitioner's employment or education[],"228 "repeatedly driving by a residence or workplace,",229 "creating fear of physical harm by ... psychological abuse or threatening acts, ${ }^{, 230}$ repeatedly telephoning or disturbing the peace of the petitioner, ${ }^{231}$ and/or causing petitioner emotional distress or injury. ${ }^{232}$

\section{d. Constitutionally Protected Parental Conduct}

Across all allegations of qualifying conduct, a minor petitioner seeking to restrain a parent will face the added challenge of establishing that his or her parent's conduct falls outside of the constitutionally protected sphere of parental decision-making and reasonable parental discipline. The guarantee of privacy accorded by the Due Process Clause of the Fourteenth Amendment conveys to parents the fundamental liberty interest in the care and control of their children. ${ }^{233}$ This interest authorizes parents to make major life decisions for their

${ }^{224}$ See, e.g., ConN. Gen. StAT. § 13-14-101 (2017); 750 Ill. ComP. Stat. 60/103 (2018); Me. Stat. tit. 19A, § 4002 (2017); Mo. Rev. Stat. § 455.010 (2017); Nev. Rev. Stat. $\S 33.018$ (2017); N.Y. FAM. CT. LAW $\S 812$ (McKinney 2018); N.Y. PENAL CODE $§ 135.60$ (Consol. 2008).

225750 Ill. COMP. StAT. AnN. 60/103 (2018).

${ }^{226} I d$.

227 Id.

${ }^{228}$ Mich. CoMP. Laws $§ 600.2950(1)$, (4) (2018).

229 N.M. STAT. ANN. § 40-13-2 (2018).

${ }^{230}$ W. VA. CODE $\S 48-27-202$ (2017).

${ }^{231}$ CAL. FAM. CODE $\$ 6320$ (West 2018).

${ }^{232}$ See., e.g., Del. Code AnN. tit. 10 § 1041(1) (2017); HAW. Rev. Stat. § 586-1 (2017) (extreme psychological abuse); 750 ILl. COMP. STAT. 60/103 (2018); N.M. STAT. ANN. § 4013-2(D) (2018) (severe emotional distress); see also Johnson, supra note 201, at 1133-34.

${ }^{233}$ Troxel v. Granville, 530 U.S. 57, 65-66 (2000) (striking down a state law allowing thirdparty petitions for child visitation rights over parental objection, holding that " $[\mathrm{t}] \mathrm{he}$ liberty interest at issue in this case - the interest of parents in the care, custody, and control of their children-is perhaps the oldest of the fundamental liberty interests recognized by this Court"); see also James G. Dwyer, Parental Entitlement and Corporal Punishment, 73 J. L. 
minor children in areas such as religion, education, and health. ${ }^{234}$ Parents are entitled to use reasonable forms of discipline to maintain control over their children and secure compliance with their directives. ${ }^{235}$

Nonetheless, parents' interest in controlling their children is not absolute. It is constrained by the state's responsibility as parens patriae to ensure the wellbeing of children ${ }^{236}$ and by the rights children themselves enjoy. ${ }^{237}$ This balance of competing rights and responsibilities means that, for a child to have an actionable claim against a parent, parental conduct must not only qualify under the relevant statute, but also be shown to exceed the bounds of constitutionally protected parenting. To overcome this hurdle, a petitioner would be required to

\& CONTEMP. PROBS. 189, 210 (2010) (reasoning that the propriety of parental use of corporal punishment should be understood as a question of the scope of parents' freedom or discretion to use particular means of discipline in exercising their liberty interests to care and control the upbringing of their children, rather than one of a parent's "right" to do so).

234 Planned Parenthood v. Casey, 505 U.S. 833, 899-900 (1992) (upholding Pennsylvania's abortion statute requiring parental consent and stating that the waiting period provided the opportunity for parental consultation to discuss the moral consequences of abortion in a familial context); Parham v. J.R., 442 U.S. 584, 588 \& n.3, 604, 620-21 (1979) (upholding Georgia's mental hospital commitment statute, which permitted parents or guardians to request that their child be committed if there was evidence of mental illness, because parental decisions regarding a child's medical care should receive great deference); Pierce v. Soc'y of the Sisters of the Holy Names of Jesus and Mary, 268 U.S. 510, 530, 534-35 (1925) (finding a state compulsory public school attendance law to unconstitutionally infringe on parental authority to direct the upbringing and education of children); Meyer v. Neb., 262 U.S. 390, 401 (1923) (holding that state restriction of school curricula to prohibit the teaching of "modern" languages other than English before the eighth grade unconstitutionally infringed on parents' liberty interest in controlling "the education of their own").

${ }^{235}$ Commonwealth v. Dorvil, 32 N.E.3d 861, 868-70 (Mass. 2015) (recognizing the common law parental privilege to use reasonable force in disciplining a child and evaluating its scope in Massachusetts and a number of other states); State v. Wilder, 748 A.2d 444, 453 (Me. 2000) (evaluating the parental privilege to use physical means of discipline under the laws of Maine and numerous states); Kandice K. Johnson, Crime or Punishment: The Parental Corporal Punishment Defense-Reasonable and Necessary, or Excused Abuse?, 1998 U. ILL. L. REV. 413, 417 (1998) (analyzing the contours of the parental privilege to use reasonable force in discipline as established by state statutes and common law and collecting relevant statutes and cases). Courts and commentators have noted that although it has not directly ruled on this question, Supreme Court precedent impliedly authorizes corporal punishment as a potentially permissible means of carrying out parents' authority to raise their children as they see fit, as it has permitted the use of corporal punishment in schools. Wilder, 748 A.2d at 453; Johnson, supra note 201, at 427-28.

${ }^{236}$ Prince v. Mass., 321 U.S. 158, 166 (1944); Santosky v. Kramer, 455 U.S. 745, 766 (1982); Troxel, 530 U.S. at 88. See generally Stacy Brustin \& Lisa Vollendorf Martin, Paved with Good Intentions: Unintended Consequences of Federal Proposals to Integrate Child Support and Parenting Time, 48 IND. L. REV. 803, 825 (2015) (parental power balanced against the state's interest through parens patriae power).

237 "Constitutional rights do not mature and come into being magically only when one attains the state-defined age of majority. Minors, as well as adults, are protected by the Constitution and possess constitutional rights." Planned Parenthood v. Danforth, 428 U.S. 52, 74 (1976). See generally Homer H. Clark, Jr., Children and the Constitution, 1992 U. ILL. L. REV. 1, 40 (collecting and summarizing constitutional cases involving children's rights). 
show that the parental conduct at issue was not an exercise of reasonable parental discipline to maintain control over the child, and was undertaken in furtherance of an improper objective. ${ }^{238}$

Depending on the circumstances, a petitioner might be able to establish that the relevant conduct does not qualify as reasonable parental discipline; for example, because it involved excessive punishment. ${ }^{239}$ To show that conduct was undertaken in furtherance of an improper objective, petitioners could argue that forcing a child to enter a marriage against his or her wishes is not within the parental prerogative, and conduct undertaken to advance that end is not for a child's benefit. ${ }^{240}$

It could be argued that the laws in several states that require parental consent to the marriage of a minor bring a child's marriage within the scope of protected parental decision making. ${ }^{241}$ Such statutes permit parents to prevent children from entering into marriages by withholding their consent to the issuance of a marriage license. Essentially, these statutes create a temporary parental veto during a defined period of minority over marriages that parents believe to be harmful or unwise. Thus, the laws preserve parents' authority to control the upbringing of children by permitting parents to delay a child's marriage until the child reaches adulthood, and perhaps preclude the union altogether if the intended spouses change their minds in the interim. These statutes do not, however, grant parents the affirmative authority to choose a child's spouse and direct a child to marry, regardless of the child's wishes. ${ }^{242}$

\section{The Impediments of Minority}

States created civil protection orders to address violence in adult relationships, and the remedy remains adult-centered. ${ }^{243}$ But most states also have made the remedy available to protect children from abuse in family and other

${ }^{238}$ Some states explicitly exempt constitutionally protected parenting activities from otherwise qualifying conduct. See, e.g., 750 ILl. COMP. STAT. 60/103 (2018) (the "reasonable direction of a minor child by a parent or person in loco parentis" does not give rise to an actionable claim of willful deprivation); N.J. STAT. ANN. § 2C:13-2 (West 2017) (establishing an affirmative defense to a charge of criminal restraint that the defendant was a relative or legal guardian who acted to restrain an unemancipated minor solely to control the child).

239 Johnson, supra note 235, at 467-69.

${ }^{240}$ Id.; see also sources cited supra note 13.

${ }^{241}$ Understanding State Statutes on Minimum Marriage Age and Exceptions, supra note 6.

${ }^{242} I d$.

${ }^{243}$ Martin, supra note 105, at 467, 487; see also Stacy L. Brustin, Legal Responses to Teen Dating Violence, 29 FAM. L. Q. 331, 339 (1995); Roger J.R. Levesque, Dating Violence, Adolescents, and the Law, 4 VA. J. SoC. POL'Y \& L. 339, 342-43 (1997); Pamela Saperstein, Teen Dating Violence: Eliminating Statutory Barriers to Civil Protection Orders, 39 FAM. L. Q. 181, 183 (2005) (noting that the issue of violence in teen dating relationships was not a concern when states started to enact domestic violence statutes). 
relationships. ${ }^{244}$ In recognition of children's age, immaturity, lack of experience, relative helplessness, and reliance on family members and others to protect them, the law accords children "minority" status to protect their interests. ${ }^{245}$ States limit children's legal rights and children's ability to control their legal affairs until they reach the age of legal majority. ${ }^{246}$ Because state law determines the ages at which minors assume various rights and duties, these ages often vary by jurisdiction. ${ }^{247}$ Children can be "emancipated" from the restrictions of minority upon the occurrence of certain life events, such as marriage or enlistment in the military, or by court order. ${ }^{248}$ Yet, emancipation alone does not automatically confer to minors all the legal rights and protections accorded to adults. ${ }^{249}$ Consequently, emancipated minors may not be viewed as adult parties when seeking civil protection orders. Whether minors can seek protection orders to prevent a forced marriage depends on whether and how states grant minors standing as protected parties and define minors' legal capacity to advance their own claims. ${ }^{250}$

\section{a. Standing}

The accessibility of civil protection orders to minors first depends on whether a jurisdiction accords them standing - the right to seek legal relief. ${ }^{251}$ A number of states expressly grant standing to some or all minors. Of these, some explicitly grant standing to minors of any age that is coextensive with the standing granted to adults, ${ }^{252}$ whereas others grant standing only to minors

${ }^{244}$ See infra Section III.C.3.b.

${ }^{245}$ KRAMER, supra note $24, \S 1: 1$, at 6.

246 Age of Majority, BLACK's LAW Dictionary 70 (9th ed. 2009); NATIONAL SuRVEY OF STATE LAws 522-25 (Richard A. Leiter ed., 7th ed. 2015) (compiling state statutes regarding emancipation and ages of majority).

${ }^{247}$ KRAMER, supra note 24, § 14:2, at 982 (citing Valley Nat'l Bank v. Glover, 159 P.2d 292 (Ariz. 1945); Jacobsen v. Lenhart, 195 N.E.2d 638, 640 (Ill. 1964); Zelnick v. Adams, 606 S.E.2d 843, 846 (Va. 2005)) (indicating the legislature's authority to establish the age of majority).

${ }^{248}$ Martin, supra note 105, at 476.

249 See Wickham v. Torley, 71 S.E. 881, 882 (Ga. 1911) (“[E]ven emancipation of the minor from parental control ... does not remove his disability and clothe him with the power to contract.”); Wuller v. Chuse Grocery Co., 89 N.E. 796, 797 (Ill. 1909) (“[T] he contract of an infant is, in general, voidable by him, and gains no additional force from the fact that he is engaged in business for himself or is emancipated."); Merrick v. Stephens, 337 S.W.2d 713, 719 (Mo. Ct. App. 1960) (finding no authority for the proposition that "solely because of emancipation, the infant is sui juris for all purposes").

${ }^{250}$ Martin, supra note 105, at 469-70.

251 Standing, BLACK's LAw Dictionary 1536 (9th ed. 2009).

${ }^{252}$ See, e.g., Alaska Stat. $\$ 18.66 .990(3)$, (5) (2017); Cal. Civ. Proc. Code $\S 372(\mathrm{~b})(1)(\mathrm{C})$ (West 2018); CAL. FAM. CODE $\S 6301$ (a) (West 2018); D.C. Code $\S 16-$ 1003(a)(1)-(5) (2018); 750 Ill. Comp. Stat. 60/214(a) (2018); OKLA. Stat. tit. 22, $\S \S 60.1 .1,60.1 .4,60.2 \mathrm{~A}(2017)$. Tennessee explicitly grants minors standing to seek protection orders based on the same qualifying relationships available to adults but does not speci- 
within a certain age group or those who share a particular relationship with the respondent. ${ }^{253}$ Consequently, a number of states clearly accord at least some minors standing to seek protection orders against parents, ${ }^{254}$ other relatives, ${ }^{255}$ individuals who are stalking or harassing them, ${ }^{256}$ and sexual assailants. ${ }^{257} \mathrm{Mi}-$ nors also have standing to seek a protection order against an intended spouse in some states if the minor shows that the respondent qualifies as a fiancé ${ }^{258}$ or dating partner. 259

For several reasons, minors arguably also have standing to seek protection orders in states with statutes that are ambiguous or silent on the issue ${ }^{260}$ First, absent a statute or constitutional provision to the contrary, children generally have the same rights to legal protection and redress for wrongs as adults. ${ }^{261} \mathrm{Se}-$

fy whether minors have standing to seek protection orders against sexual assailants or stalkers. See TENN. CODE ANN. § 36-3-601(5) (2017).

253 See, e.g., IOWA CODE $\$ 236.2$ (2017) (granting minors standing against spouses, intimate partner cohabitants, and dating partners); Mo. REV. STAT. \$§ 455.010(2), (7) (2017) (restricting civil protection orders to adults and defining adult as an individual aged seventeen and older); OR. REV. STAT. § 107.726 (2018) (granting standing to minor spouses and minors in sexually intimate relationships if the respondent is eighteen years of age or older); WYo. STAT. ANN. § 35-21-102(a) (2017) (defining "adult" to include any person who is either at least sixteen years old or legally married); D.M.H. ex rel. Hefel v. Thompson, 577 N.W.2d 643, 646 (Iowa 1998).

254 See infra APPENDIX 4.

255 See infra APPENDIX 4.

256 See infra APPENDIX 4.

${ }^{257}$ See infra APPENDIX 4.

258 See infra APPENDIX 4.

259 See infra APPENDIX 4.

${ }^{260}$ Courts in several states have interpreted ambiguous protection order statutes to extend standing to minors. See D.M.H. ex rel. Hefel, 577 N.W.2d at 646; Beermann v. Beermann, 559 N.W.2d 868, 869-70, 874 (S.D. 1997); Katherine B.T. v. Jackson, 640 S.E.2d 569, 576 (W. Va. 2006).

${ }^{261}$ Sorenson v. Sorenson, 339 N.E.2d 907, 912 (Mass. 1975); see also Petersen v. City \& Cty. of Honolulu, 462 P.2d 1007, 1009 (Haw. 1969) (“"I]n general, minor children are entitled to the same redress for wrongs done them as are any other persons.") (citing Dunlap v. Dunlap, 150 A. 905, 906 (N.H. 1930)); Wilbon v. D.F. Bast Co., 382 N.E.2d 784, 790-91 (IIl. 1978) ("[A] minor should not be precluded from enforcing his rights unless clearly debarred from so doing by some statute or constitutional provision.") (citing Walgreen Co. v. Indus. Comm'n, 153 N.E. 831, 833 (Ill. 1926)); Norris v. Mingle, 29 N.E.2d 400, 402 (Ind. 1940) (" $[\mathrm{A}]$ minor should not be precluded from enforcing his rights unless the same are clearly barred on account of some statutory or constitutional provision."); Gillette v. Del. L. \& W.R. Co., 102 A. 673, 673 (N.J. 1917) (holding that an infant's minority does not prevent him from initiating suit to redress legal claims); Henry ex rel. Henry v. City of N.Y., 724 N.E.2d 372, 374 (N.Y. 1999) (“[A]n infant's right of action 'at its origination is and remains in the infant. ... Infancy does not incapacitate the infant from bringing the action.' ") (quoting Murphy v. Vill. of Fort Edward, 107 N.E. 716, 717 (N.Y. 1915)); Harrison v. Wallton's Ex'r, 30 S.E. 372, 373 (Va. 1898) (holding that minors can bring suit through adult representatives to enforce their rights during their minority); Hunter v. N. Mason High Sch., 529 P.2d 898, 899 (Wash. Ct. App. 1974) ("The legal disabilities of minors have been firmly established by common law and statute. They were established for the protection of minors, 
cond, constitutional provisions and statutes in several states explicitly guarantee to minors a general right to access the courts for redress of grievances. ${ }^{262}$ Third, by establishing the procedures to be followed when courts are presented with claims by minor parties who lack legal capacity to sue, court rules in many states manifest a presumption that individuals of any age are entitled to pursue legal claims. ${ }^{263}$ Furthermore, because protection order statutes are remedial in nature, the principle of liberal construction dictates that courts should construe such statutes liberally to benefit the class of individuals that the statutes were intended to protect. ${ }^{264}$ Applying this principle, courts faced with a choice be-

and not as a bar to the enforcement of their rights.") (citing 43 C.J.S. Infants $§ 19$ (1945)), aff'd, 539 P.2d 845 (Wash. 1975); Lee v. Comer, 224 S.E.2d 721, 722-23 (W. Va. 1976) ("We perceive no reason why minor children should not enjoy the same right to legal redress for wrongs done to them as others enjoy.").

${ }^{262}$ Sara Jeruss, Empty Promises? How State Procedural Rules Block LGBT Minors from Vindicating Their Substantive Rights, 43 U. S.F. L. REV. 853, 905-09 tbl.1 (2009) (compiling state constitutional provisions and statutes according minors a right of access to the courts).

263 Alison M. Brumley, Comment, Parental Control of a Minor's Right to Sue in Federal Court, 58 U. CHI. L. REv. 333, 356 (1991) ("Congress designed [Federal Rule of Civil Procedure] Rule 17(c) to promote and protect the ability of minor plaintiffs and defendants to pursue their legal interests with such guidance as the trial court deems necessary in the best interests of the minor. The rule reflects a belief that minors as well as adults should have access to the courts to protect their legal rights."); Jeruss, supra note 262, at 872-73, 910-34 tbl.2 (detailing the laws and court rules addressing minors' legal capacity in the fifty states and noting that nearly all states have incorporated Rule 17(c) of the Federal Rules of Civil Procedure into their statutes, or contain a similar rule requiring that a guardian or next friend appear on behalf of minors).

${ }^{264}$ See, e.g., 750 ILl. COMP. STAT. 60/102 (2018) ("This Act shall be liberally construed and applied to promote its underlying purposes. ..."); OHIO REV. CODE ANN. § 1.11 (West 2017) ("Remedial laws and all proceedings under them shall be liberally construed in order to promote their object and assist the parties in obtaining justice."); W. VA. CODE § 48-27-101(b) (2017) ("This article shall be liberally construed and applied to promote the following purposes: (1) To assure victims of domestic violence the maximum protection from abuse that the law can provide..."); Salvattera v. Ramirez, 105 A.3d 1003, 1010 (D.C. 2014) (" "the plain intent of the legislature was an expansive reading of the Act'; it 'must be liberally construed in furtherance of its remedial purpose." ") (quoting Araya v. Keleta, 31 A.3d 78, 81 (D.C. 2011)); Rinas v. Engelhardt, 818 N.W.2d 767, 772 (N.D. 2012) ("As a remedial statute, [the statute] is to be construed liberally to allow courts to accomplish the goal of protection orders, which is protecting victims of domestic violence from further harm"); Saville v. Ude, 776 N.W.2d 31, 35 (N.D. 2009) ("As a remedial statute, the provisions of § 14-07.102 are construed liberally, allowing the courts to accomplish the objectives behind protection orders.”); Raynes v. Rogers, 955 A.2d 1135, 1140 (Vt. 2008) (as a remedial statute, Vermont's Abuse Prevention Act "must be liberally construed to 'suppress the evil and advance the remedy intended by the Legislature.'") (quoting Dep't of Corr. v. Human Rights Comm'n, 917 A.2d 451, 454 (Vt. 2006)); Swensen v. Swensen, 490 N.W.2d 668, 670 (Minn. Ct. App. 1992) ("As a remedial statute, the Domestic Abuse Act receives liberal construction ... in favor of an injured person."); N.J. Div. CRIMINAL Justice, Legal ASPECTS OF Domestic Violence Student Manual 2-1 (2003) ("The provisions of the domestic violence laws should be liberally construed by the law enforcement officer in favor of action protecting a victim of domestic violence," referencing N.J. STAT. ANN. § 2C:25-19). 
tween alternate interpretations of protection order statutes should select those that provide the greatest protection for victims of abuse. ${ }^{265}$ Finally, public policy supports extending standing to all individuals, regardless of age, when the law is silent to instill confidence in the legal system and to encourage those who need help to seek it. ${ }^{266}$ For all of these reasons, where protection order statutes are ambiguous, minors should be presumed to have the same standing to seek relief as adults.

Minors clearly lack standing to seek domestic violence civil protection orders under any circumstances in at least one state, ${ }^{267}$ and lack standing to file against parents ${ }^{268}$ or other relatives ${ }^{269}$ in several others. Emancipated minors are treated differently across states. Whereas several states explicitly confer standing on emancipated minors as adults, ${ }^{270}$ at least one state explicitly treat some emancipated minors as minors for purposes of the protection order remedy. ${ }^{271}$

Several states explicitly grant standing to adults to seek protection orders on minors' behalf. Some do so restrictively, granting standing only to adults who share a particular relationship with a minor, including parents, guardians, and custodians, ${ }^{272}$ family or household members $;{ }^{273}$ or those who play a particu-

${ }^{265}$ See, e.g., Katherine B.T., 640 S.E.2d at 576 (finding that minors have standing to seek protection orders as "persons" based, in part, on the principle of liberal construction codified within the statute).

${ }^{266}$ Buckholz v. Leveille, 194 N.W.2d 427, 427 (Mich. Ct. App. 1971) (“Courts must stand prepared to protect the rights of all citizens, including teenagers. Denying a teen-aged litigant access to our courts simply because he happens to be a minor not only tends to lessen the confidence of young people in our legal system but adds credence to the existence of the 'generation gap.' And it may even help widen that gap."); see Martin, supra note 105, at $514-15$.

267 WIS. STAT. $\$ 813.12(1)$ (am) (2017) (defining "domestic abuse" as only being perpetrated by and against "adult[s]"). Minors do have standing to seek protection orders against sexual assault and stalking in Wisconsin. WIS. STAT. § 813.125(2)(b) (2017); see also Mo. REv. STAT. § 455.010(2), (7) (2017) (restricting civil protection orders to adults and defining adult as an individual aged seventeen and older); WYO. STAT. ANN. § 35-21-102(a) (2017) (defining "adult" to include any person who is either at least sixteen years old or legally married).

268 See infra APPENDIX 4.

269 See infra APPENDIX 4.

270 See Ala. Code $§ 30-5-5$ (a)(1) (2017); ME. Stat. tit. 19-A, § 4002(2) (2017); MisS. CodE ANN. § 93-21-3(b) (2017) (emancipation by marriage); Mo. ReV. STAT. § 455.010(2) (2017); N.J. Stat. ANN. § 2C:25-19(a), (d), (e) (West 2017); OKLA. STAT. tit. 22, § 60.1(1) (2017); 8 R.I. GEN. LAWS § 8-8.1-1(1), (3) (2017); TENN. CODE ANN. § 36-3-601(2) (2017).

${ }^{271}$ ARK. CODE ANN. § 9-15-201(d) (2017) (married minors).

272 See infra APPENDIX 5. The Vermont Supreme Court interpreted its statute to confer standing only to parents to seek protection orders on behalf of minors. See Wood ex rel. Eddy v. Eddy, 833 A.2d 1243, 1245 (Vt. 2003) (agreeing that a mother had standing to seek a protection order on behalf of her minor daughter); Bigelow v. Bigelow, 721 A.2d 98, 100 (Vt. 1998) (holding that the statute "does not encompass petitions by third parties, even grandparents, on behalf of minor children.").

273 See infra APPENDIX 5. 
lar professional role, such as district attorneys,${ }^{274}$ domestic violence program or shelter staff and volunteers, ${ }^{275}$ guardians ad litem, ${ }^{276}$ or representatives of state agencies. ${ }^{277}$ Other states permit a broader array of adults to represent minors' interests. ${ }^{278}$ More restrictive definitions of qualifying adults may present barriers in the forced marriage context, as minor petitioners may be seeking to restrain the very adults upon whom they must rely to advance claims for protection.

\section{b. Capacity}

The accessibility of protection orders for minors depends not only on whether minors have standing to sue, but also on whether they have the legal capacity to represent their own interests in the litigation. Capacity is a party's "satisfaction of a legal qualification, such as legal age or soundness of mind, that determines one's ability to sue or be sued." 279 Minors generally lack the capacity to take civil legal action independently; instead, they typically must advance legal claims through an adult representative. ${ }^{280}$

Concerns about the prevalence of dating violence and sexual assault victimization among teens, coupled with data showing teens' reluctance to disclose such abuse to adults, have led several states to depart from this general rule and grant adolescents the legal capacity to seek protection orders independently. ${ }^{281}$ Several states grant capacity to seek protection orders to all minors who have reached a minimum age $\mathrm{e}^{282}$ and/or share a particular relationship with the respondent ${ }^{283}$ Other states require courts to assess capacity on a case-

274 See infra APPENDIX 5.

275 See infra APPENDIX 5.

276 See infra APPENDIX 5.

277 See infra APPENDIX 5.

278 See infra APPENDIX 5.

279 Capacity, BLACK's LAw DiCTIONARY (10th ed. 2014).

2802 Thomas A. Jacobs, Children And the Law: Rights and Obligations $§ 11: 13$ (2012) (unemancipated minors generally do not have capacity to sue); 4 JAMES WM. MoOre, MoOre's Federal Practice I 17.21[3][a] \& n.16 (3d ed. 2014); Linda D. Elrod, Client-Directed Lawyers for Children: It Is the "Right" Thing to Do, 27 PACE L. REv. 869, 878-79 (2007) (providing a historical overview of children's legal rights).

${ }^{281}$ See infra APPENDIX 5.

${ }^{282}$ Compare Cal. Civ. Proc. Code $\S 372(b)(1)(C)-(D)$ (West 2018); Cal. Fam. Code $\S 6301$ (a) (West 2018) (granting minors twelve and older capacity to seek protection orders on their own against any qualifying respondent), with Mo. REV. STAT. §§455.010(2), 455.020 (2016) (minors seventeen and older can seek protection orders on their own against any qualifying respondent).

${ }^{283}$ Compare D.C. CODE $§ 16-1003(a)(2)-(3)$ (2018) (granting minors twelve and older capacity to seek protection orders against intimate partners, and minors 16 and older against any qualifying respondent), with TEX. FAM. CODE ANN. § 82.002(b)(1) (West 2017) (granting minors of any age capacity to seek protection orders against dating partners). 
by-case basis. ${ }^{284}$ When a minor appears in court with no adult representative to seek a protection order, states authorize courts to take varying steps to protect the minor's interests, including appointment of an attorney ${ }^{285}$ or a guardian $a d$ litem. ${ }^{286}$

On the other end of the spectrum, a handful of states make clear that minors lack capacity to proceed independently in protection order proceedings, and authorize certain adults to represent minor petitioners' interests. ${ }^{287}$ At least one state deprives otherwise emancipated minors of capacity in protection order proceedings. ${ }^{288}$

Most protection order statutes are silent or ambiguous regarding minors' capacity to represent their own interests. ${ }^{289}$ In such jurisdictions, statutes, case law, and court rules governing capacity often permit courts to determine what is needed to protect the minor's interests in the litigation. ${ }^{290}$ Courts in states that

${ }^{284}$ See, e.g., ARIZ. REV. STAT. ANN.§ 13-3602(A) (2017) (parents, guardians, and custodians generally must file petitions for minor victims "unless the court determines otherwise"); MinN. STAT. § 518B.01(4)(a) (2017) (minors sixteen and older can be granted capacity to seek protection orders on their own against spouses or co-parents "if the court determines that the minor has sufficient maturity and judgment and that it is in the best interests of the minor").

${ }^{285}$ See, e.g., D.C. CoDE $\S 16-1005(\mathrm{a}-1)(4)$ (2018) (court may appoint an attorney to represent the interests of a minor who appears without an adult representative if such appointment will not unduly delay adjudication of the case).

${ }^{286}$ CAL. Civ. Proc. Code $§ 372$ (b)(1) (West 2018) (a court may appoint a guardian ad litem, after considering any objections by the minor petitioner to the appointment of particular individuals and if the appointment will not unduly delay adjudication of the case).

287 See, e.g., ALA. CODE $\S \S 30-5-2(4), 30-5-5(a)(1)-(2)$ (2017) (providing that only adults may seek protection orders, and permitting protection orders to be filed by plaintiffs or by parents, guardians, custodians, or the State Department of Human Resources on behalf of minors); ARK. CODE ANN. §9-15-201(d)(2), (4) (2017) (requiring protection orders to be filed on behalf of minors by adult family or household members or by people working for domestic violence shelters and programs); GA. CODE ANN. § 19-13-3(a) (2017) (“A person who is not a minor may seek relief under this article by filing a petition with the superior court alleging one or more acts of family violence. A person who is not a minor may also seek relief on behalf of a minor by filing such a petition."); LA. STAT. ANN. § 46:2133(D) (2017) ("An adult may seek relief under this Part by filing a petition with the court alleging abuse by the defendant. Any parent, adult household member, or district attorney may seek relief on behalf of any minor child. ..."); ME. STAT. tit. 19-a, § 4005(1) (2017) (permitting only adults responsible for a minor or the department of child and family services to seek a protection order on behalf of a minor); 23 PA. CONS. STAT. $§ 6106(a)$ (2018) (“An adult or an emancipated minor may seek relief under this chapter for that person or any parent, adult household member, or guardian ad litem may seek relief under this chapter on behalf of minor children . . . by filing a petition with the court alleging abuse by the defendant.").

${ }^{288}$ See ARK. CODE ANN. § 9-15-201(d)(2), (4) (2017) (classifying married minors as minors for capacity purposes).

${ }^{289}$ Martin, supra note 105 , at 483.

290 See, e.g., CAL. Civ. Proc. Code § 372(b)(1) (West 2018); Мich. CT. R. 3.703(F)(1) (providing that minor petitioners in protection order proceedings must proceed through next friends, who must be adults not statutorily disqualified from service. Next friends are authorized to serve without court appointment where a minor is fourteen or older); Parrish v. Price, 
follow Federal Rule of Civil Procedure 17(c) have the discretion to appoint a next friend, guardian ad litem, or make any other order ensuring a minor's interests are adequately protected, including permitting a minor to proceed alone. ${ }^{291}$ Courts do not have this latitude in all states, and a number of states require courts to appoint adults to represent the interests of minor parties in all

71 So. 3d 132, 133 (Fla. Ct. App. 2011) (holding minors have standing to seek domestic violence injunctions but lack capacity to do so on their own; they must have an appointed representative or a next friend); Beermann v. Beermann, 559 N.W.2d 868, 870-71 (S.D. 1997) (holding where a minor seeks a civil protection order without an adult representative, trial courts have the discretion to appoint a guardian ad litem or conclude that no guardian is necessary and permit the minor to proceed alone). Judicial benchbooks in some states provide guidance to courts regarding capacity where statutes are ambiguous. See, e.g., Colo. Domestic Violence Benchbook, Ch. 2, at 2-3 (2014) (protection orders may be sought to protect minors if action is brought through a person empowered to act on the minor's behalf); Commonwealth of Ma. Trial Court Guidelines for Judicial Practice: Abuse Prevention ProceEding 19 (2011), http://www.mass.gov/courts/docs/209a/guidelines2011.pdf [https://perma.cc/9JZU-S7DJ]. ("The court should not refuse to act solely because the court cannot secure the presence of a parent or guardian, particularly where the minor is mature (16 or 17), and where the defendant is an intimate partner or a family member who is not a parent or guardian or where there is an imminent threat of bodily injury."). An attorney general opinion addresses this issue in Virginia, Op. Att'y Gen. 10-116, at 1,4 (2011) (opining that only emancipated minors have capacity to file a petition for a protection orders without an adult representative; minors may appear before a magistrate to seek an emergency temporary protection order on their own).

${ }^{291}$ See Fed. R. Civ. P. 17(c); GA. CODE AnN. § 9-11-17(c) (19857); KAn. STAT. AnN. § 60217(c) (West 2010); OKLa. Stat. AnN. tit. 12, § 2017(c) (West 1984); S.D. CodifiEd LaWS § 15-6-17(c) (2017); Ala. R. CIV. P. 17(c); Alaska R. Civ. P. 17(c); ARIZ. R. Civ. P. 17(f); Colo. R. Civ. P. 17(c); Del. SuP. CT. R. CIV. P. 17(c); Fla. R. Civ. P. 1.210(b); Haw. R. Civ. P. 17(c); IdAho R. Civ. P. 17(c); Me. R. Civ. P. 17(b); Mass. R. Civ. P. 17(b); Miss. R. Civ. P. 17(c); Mont. R. Civ. P. 17(c); Nev. R. Civ. P. 17(c); N.M. Dist. CT. R. Civ. P. 1-017(d); N.D. R. Civ. P. 17(b); OHio R. Civ. P. 17(B); S.C. R. Civ. P. 17(c); TenN. R. Civ. P. 17.03; VT. R. CIV. P. 17(b); WyO. R. CIV. P. 17(c); Gardner ex rel. Gardner v. Parson, 874 F.2d 131, 140 (3d Cir. 1989) ("under Rule 17(c), a court may appoint a guardian, or it may decline to do so if the child's interests may be protected in an alternative manner."); M.S. v. Wermers, 557 F.2d 170, 174 (8th Cir. 1977) (stating the "[a]ppointment of a guardian ad litem is considered to be discretionary under the Federal Rules, provided the District Court enters a finding that the interests of the minor are adequately protected in the event it does not make such appointment."); Roberts v. Ohio Cas. Ins. Co., 256 F.2d 35, 39 (5th Cir. 1958) ("We spell out the [Federal Rule of Civil Procedure 17(c)] to mean: (1) as a matter of proper procedure, the court should usually appoint a guardian ad litem; (2) but the [c]ourt may, after weighing all the circumstances, issue such order as will protect the minor in lieu of appointment of a guardian ad litem; (3) and may even decide that such appointment is unnecessary, though only after the [c]ourt has considered the matter and made a judicial determination that the infant is protected without a guardian."); see also Beermann, 559 N.W.2d at 870-71 (holding that where a minor seeks a civil protection order without an adult representative, trial courts have the discretion to appoint a guardian ad litem or conclude that no guardian is necessary and permit the minor to proceed alone). But see Katherine B.T v. Jackson, 640 S.E.2d 569, 577 (W.Va. 2006) (holding that West Virginia Rule of Civil Procedure 17(c) requires that "a minor must have either a next friend or guardian in order to prosecute or defend civil actions generally."). See also Jeruss, supra note 262, at 875-78, 905-09 (comparing state procedural rules to the Federal Rule of Civil Procedure 17(c)). 
proceedings. ${ }^{292}$ Several states permit minors aged fourteen and older to select their adult representatives, subject to court approval. ${ }^{293}$

Given the limited data on forced marriage in the United States and the limited experience of domestic violence agencies with forced marriage cases, the extent to which minors seeking to avoid forced marriages would benefit by extensions of capacity is unclear. States often have extended legal capacity to minors in protection order proceedings to encourage minors to seek help by eliminating the need for minors to first disclose abuse to parents or other adults. ${ }^{294}$

It is possible that minors facing marriages forced by their parents might seek the support of another adult before pursuing legal protection. In such circumstances, statutory provisions limiting the adults who can assist minors to file for protection orders may create a significant obstacle. ${ }^{295}$ Conversely, it is possible that minors concerned about protecting their families from scrutiny or gossip might be willing to proceed only if they do not need to recruit an adult representative. Research on the needs and desires of minors who could benefit from civil injunctive relief to prevent forced marriage is sorely needed to inform states as they consider policies to address this issue.

\section{Remedies}

Protection orders offer a wide range of remedies for protected parties and provide courts flexibility in crafting individually tailored relief. ${ }^{296}$ Civil protection order statutes typically include an enumerated list of potential remedies that address common problems within the domestic violence context. Such lists often include: prohibitions on assaulting, harassing, threatening, or stalking the petitioner; stay-away and no-contact orders; orders to vacate a joint residence; temporary custody and support awards; mandated domestic violence or substance abuse counseling; monetary awards; and temporary possession of auto-

292 See, e.g., Mo. Rev. STAT. § 507.110 (2017); Neb. ReV. STAt. § 25-307 (2017); N.Y. C.P.L.R. 1201 (McKinney 2018); WIS. STAT. § 803.01(3)(a) (2017); ARK. R. CiV. P. 17(b); Iowa R. Civ. P. 1.210; Ky. R. Civ. P. 17.03(1)-(2); LA. Code Civ. Proc. AnN. art. 683(D) (2017); Mich. Ct. R. 2.201(E); Minn. R. Civ. P. 17.02; OR. R. Civ. P. 27(A); PA. R. Civ. P. 2027; UTAH R. CiV. P. 17(b).

293 See, e.g., Ariz. Rev. Stat. AnN. § 14-5203 (2017); CAl. Civ. Proc. Code § 373(a)-(c) (West 2018); Mont. Code AnN. § 25-5-301(1)-(2) (2017); Nev. Rev. Stat. § 12.050(1)-(2) (2017); N.Y. C.P.L.R. 1202(a)(1) (McKinney 2018); N.D. CENT. CODE § 28-03-01 (2017); Wash. Rev. Code. § 4.08.050(1)-(2) (2017); WIS. STAT. § 803.01(b)(2)-(3) (2017); Ala. R. Civ. P. 17(d); Мich. Ct. R. 2.201(E)(2); MinN. R. Civ. P. 17.02; OR. R. Civ. P. 27(B)(1)(a)(B)(2)(b); S.C. R. CIV. P. 17(d)(3); UTAH R. Civ. P. 17(c)(1).

${ }^{294}$ Martin, supra note 105, at 462-63.

295 Tennessee, for example, permits unemancipated minors to file petitions for protection orders against a parent only if the petition is signed by another parent or legal guardian. TENN. CODE ANN. §36-3-602(b) (2017) (permitting unemancipated minors to file petitions signed by caseworkers against other parties, but only petitions signed by a parent or legal guardian against a parent or legal guardian).

${ }^{296}$ E.g., GOODMAN \& EPSTEIN, supra note 118 , at 79. 
mobiles and other personal property. ${ }^{297}$ In addition to these enumerated remedies, many states also authorize courts to award "catch-all" relief-any other (constitutionally permissible) orders appropriate to the resolution of the case. ${ }^{298}$

Because enumerated remedies were not crafted with forced marriage in mind, they may not be sufficient to meet the needs of petitioners seeking protection in this context, and may not provide courts with a reliable guide to meet common areas of need. As a result, catch-all provisions may best enable courts to craft remedies targeted to meet the specific needs of petitioners facing forced marriage. In the states lacking provisions for catch-all relief, protection orders may have more limited utility to prevent forced marriage, particularly for petitioners who wish to continue to live or remain in close contact with their families. ${ }^{299}$

\section{The Efficacy of Civil Protection Orders to Prevent Forced Marriage}

Despite the challenges identified, civil protection orders show promise as a remedy to prevent forced marriage. Indeed, because forced marriage is a type of domestic abuse and gender-based violence, it is natural that individuals would turn to civil protection orders to address this problem. ${ }^{300}$ Like individuals facing other forms of domestic and family violence, those facing forced marriage often need emergency intervention, low barriers to entering the civil justice system, and individually tailored solutions. ${ }^{301}$ Moreover, those facing forced marriages often have close and ongoing relationships with the individuals from whom they need protection. The resulting emotional dynamics, the tactics used by respondents, and the underlying dynamic of control all should be familiar to courts accustomed to adjudicating petitions for protection orders in cases of domestic and family violence.

Nonetheless, because civil protection orders were not created with forced marriage in mind, it is unsurprising that the fit between protection orders and

297 CAL. FAM. CODE $§ 6220$ (West 2018); D.C. CoDE $§ 16-1005$ (c) (2018); Hart, supra note 116 , at 15; Johnson, supra note 201, at 1111; Klein \& Orloff, supra note 115 , at 913-14, 916-18, 925, 931-32, 937-38, 944, 954, 999; Stoever, supra note 111, at 1044. When first enacted, protection order remedies often were limited to directives to stay away from and refrain from further assaulting, harassing, or threatening a petitioner. States have amended protection order laws since that time to expand available remedies to address other pressing concerns faced by individuals subjected to abuse. GOODMARK, supra note 119, at 17.

${ }^{298}$ The District of Columbia, for example, permits the Court to direct the Respondent "to perform or refrain from other actions as may be appropriate to the effective resolution of the matter." D.C. CODE § 16-1005(11) (2018); Klein \& Orloff, supra note 115, at 912; see also A.B.A. Comm'n on Domestic and Sexual Violence, Domestic Violence Civil PROTECTION ORDERS (CPOS) (2016) (collecting state protection order provisions regarding catch-all relief).

299 VIGIL, REPORT TO THE HOUSE, supra note 7, at 6.

300 See supra Section II.B.

301 See supra Part I and Section II.B. 
forced marriage is awkward at best. Today, the availability of civil protection order to prevent an impending forced marriage depends not on whether a petitioner legitimately fears that she will be forced to marry against her will, but rather on her age, her relationship with those attempting to coerce her, whether the tactics used against her qualify as criminal acts, whether a qualifying adult is required and willing to assist her, and whether available remedies address her concerns.

The terms under which protection orders are available to prevent or intervene in a forced marriage vary considerably between states. Generally speaking, protection orders are most likely to be available to individuals who are subjected to acts or threats of physical violence by parents, relatives, household members, or spouses. This group most closely overlaps with petitioners seeking relief from domestic abuse outside of the forced marriage context. Significant gaps in relief exist for individuals facing or trapped in forced marriages who are subjected to nonviolent forms of coercion and for minors who feel unable to confide in an adult who would be qualified to seek relief on their behalf. Yet, even these groups are clearly eligible to seek relief in several states.

So long as forced marriage-based protection order claims must be shoehorned into these constructs, the actual availability of protection orders to prevent and intervene in forced marriages will remain uncertain. Access will depend foremost on whether those facing forced marriages have the support of experts who understand and can inform them about the remedy and assist them through the process.

\section{RESTRAINING FORCED MARRIAGE}

Although civil protection orders can be used to prevent forced marriage in many circumstances, the complexities of doing so undermine the viability of the remedy as a widely accessible tool. Because individuals facing forced marriages often experience numerous pressures to submit, stay silent, and not dishonor their families, it is especially important that legal remedies are structured to encourage potential victims to seek help. ${ }^{302}$ To ensure that potential victims can reliably access civil legal protection to prevent forced marriage, states should create a new remedy specifically tailored to address this problem. Many of the shortcomings of civil protection order statutes in the forced marriage context have been identified as undermining the efficacy of the remedy to redress domestic violence as well. ${ }^{303}$ The creation of forced marriage protection orders presents an opportunity to implement reforms on a smaller scale that also could be adopted in the broader civil protection order context. This section addresses the benefits and possible criticisms of these proposed reforms.

302 VIGIL, REPORT TO THE HOUSE, supra note 7, at 8.

303 GoOdmark, supra note 119 , at 45 ; Johnson, supra note 201 , at 1111 ; GoOdMAN \& EPSTEIN, supra note 118, at 77. 


\section{A. Specialization}

To redress the challenges posed to potential forced marriage victims under existing civil protection order statutes, lawmakers could reform those statutes, or, alternatively, create a new injunctive remedy specifically designed to prevent and redress forced marriage. The United Kingdom took this approach when it created forced marriage protection orders (FMPOs) in 2007. Establishing FMPOs in the United States would bring several benefits less easily achieved through the reform of existing protection order laws, including: aligning the remedy with the lived experiences of potential victims; informing potential victims, advocates, and other support persons that legal protection is available; and communicating the state's opprobrium of the practice and support for potential victims. To achieve these goals, FMPOs should be defined according to, and offer relief tailored to, the experiences of individual petitioners.

\section{A Model for Reform}

The United Kingdom enacted the Forced Marriage (Civil Protection) Act 2007. ${ }^{304}$ Under this Act, individuals are eligible to seek Forced Marriage Protection Orders (FMPOs) if they are being forced, facing attempts to be forced, or have been forced into a marriage. ${ }^{305}$ "Force" includes threats and psychological coercion, and orders can be issued based on conduct that occurred within the U.K. or abroad. ${ }^{306}$ Individuals seeking to be protected can apply for FMPOs on their own behalf, and designated government agencies and other individuals granted leave of court also can apply for FMPOs on behalf of another individual. ${ }^{307}$ Minors may represent their own interests in FMPO proceedings if they appear with a legal representative or if the court agrees, or, alternatively, may have a next friend represent their interests. ${ }^{308}$ Forced Marriage Protection Orders can restrain not only respondents directly attempting to force a marriage, but also others who assist, counsel, encourage, or conspire with the respondent. ${ }^{309}$ In determining whether to issue an FMPO, the court must consider all relevant circumstances, including "the need to secure the health, safety and

${ }^{304}$ Forced Marriage (Civil Protection) Act 2007, c. 20, (U.K.) http://www.legislation.go v.uk/ukpga/2007/20/pdfs/ukpga_20070020_en.pdf [https://perma.cc/GTT8-PMKV].

${ }^{305}$ Id. $\S 63 \mathrm{~A}(1)(\mathrm{a})-(\mathrm{b})$.

306 Id. $\$ 63 \mathrm{~A}(6)$.

${ }^{307}$ Id. $\S 63 \mathrm{C}(1)-(3)$.

${ }^{308}$ Forced Marriage Protection Orders: How Can They Protect Me?, HM COURTS \& TRIBUNAL SERVICE FL701, at 2 (Apr. 2017), https://formfinder.hmctsformfinder.justice.g ov.uk/fl701-eng.pdf [https://perma.cc/V6RZ-DBRH] [hereinafter How Can They Protect $M e$ ?].

309 Forced Marriage (Civil Protection) Act 2007, c. 20, 63B(3)(a), (U.K.) http://www.legislation.gov.uk/ukpga/2007/20/pdfs/ukpga_20070020_en.pdf [https://per ma.cc/GTT8-PMKV]. 
well-being of the person to be protected." ${ }^{310}$ In assessing the petitioner's wellbeing, the court must consider the expressed wishes of the person to be protected, as appropriate given the petitioner's age and level of understanding. ${ }^{311}$ Courts may include within the terms of FMPOs "such prohibitions, restrictions or requirements ... and ... such other terms ... as the court considers appropriate for the purposes of the order." ${ }^{312}$ Common FMPO provisions include prohibitions against facilitating, organizing, or permitting a marriage ceremony to occur, and against applying for or using a passport to remove the petitioner from the United Kingdom. Forced Marriage Protection Orders also can include protections for third parties at risk of harm from one or more respondents, such as a petitioner's current or former dating partner. ${ }^{313}$ Although FMPOs may be enforced through civil contempt or criminal prosecution, ${ }^{314}$ enforcement proceedings have been exceedingly rare. ${ }^{315}$

Enacting a version of FMPOs across the United States would have several potential benefits for those facing forced marriages.

\section{Forced Marriage as the Relationship}

Forced marriage is a form of violence worthy of legal protection regardless of the identity of the perpetrator. Unlike domestic violence, which is often an ongoing campaign by one intimate partner or family member to control another, forced marriage can be a group effort. This group can include central persons in a petitioner's life, such as parents and close relatives, as well as acquaintances and individuals a petitioner does not know well, such as an intended spouse's relatives. Moreover, like sexual assault and stalking, forced marriage is a form of violence against women that both stems from and promotes the subordination of women and girls. ${ }^{316}$ Preventing and redressing forced marriage in all contexts elevates the status of women and girls, and promotes equality. ${ }^{317}$ For all of these reasons, making FMPOs available against

${ }^{310} I d . \S 63 \mathrm{~A}(2)$.

311 Id. $\$ 63 \mathrm{C}(4)(\mathrm{c})$

${ }^{312} I d . \S 63 \mathrm{~B}(1)$.

${ }^{313} I d . \S 63 \mathrm{~B}(3)$; see also Anne-Marie Hutchinson, Lessons for the US from UK Experiences with Forced Marriage Protection Orders and Abusive Transnational Marriages, TAHIRIH JUST.CENTER,(2013), http://preventforcedmarriage.org/wp-content/uploads/2015/02/Less ons-from-the-UK-on-FMPOs-and-Abusive-Intl-Marriages-with-Anne-Marie-Hutchinson.pdf [https://perma.cc/NM3T-QBSA].

${ }^{314}$ How Can They Protect Me?, supra note 308; Anti-Social Behaviour, Crime and Policing Act 2014, c. 12, § 63C(A) (U.K.).

315 Goodman \& EpsteIn, supra note 118, at 80; Nick McCarthy, Revealed: Police Secure Court Orders to Protect Victims of Forced Marriage, BIRMINGHAM MAIL (Jan. 4, 2017 12:48 PM), https://www.birminghammail.co.uk/news/midlands-news/revealed-police-secure-courtorders-12403573 [https://perma.cc/5R3N-A4QP].

316 See supra Section I.E.

317 See supra Section I.E. 
any individual who is forcing or has forced another into a marriage would maximize the remedy's efficacy.

\section{Forced Marriage as the Conduct}

A primary limitation of civil protection orders as a forced marriage remedy lies in the primacy placed on individual acts in lieu of the broader dynamic. ${ }^{318}$ Protection order statutes require courts to parse respondents' conduct to evaluate whether any individual actions crossed the legal threshold qualifying a petitioner for relief. This qualifying conduct test excludes individuals from relief who have a qualifying relationship with a respondent, and legitimately fear they are being forced into a marriage, but who have not been subjected to designated tactics (or at least not yet) The limited data available on forced marriage in the U.S. suggests that although physical violence is not rare, emotional and psychological tactics are far more prevalent. ${ }^{319}$ The focus on physical violence and criminal conduct in many states may make legal protection unavailable to individuals who have suffered non-violent means of coercion. Legal protection is perhaps similarly unavailable to those who have learned to act compliant after witnessing violence against older siblings who attempted to resist marriage, and thereby have avoided victimization themselves.

To best protect against forced marriage, the law must recognize forced marriage as the harm to be prevented, whatever the tactics used to achieve that end. Thus, a court's inquiry must center on whether a forced marriage is at risk or has occurred. "Force" should be defined broadly, to include emotional, psychological, and financial means of coercion, as well as acts and threats of physical and sexual violence. Because plans for an individual's marriage may be made years in advance of the marriage date, courts should be empowered to examine the totality of a respondent's conduct over time when assessing whether it amounts to "force." This analysis should be undertaken from the perspective of the petitioner, since whether a marriage is being forced upon an individual fundamentally depends on that individual's understanding of the events and his or her own reaction to the plans (assuming that individual has some advanced knowledge) ${ }^{320}$ Focusing on a petitioner's experience also might help courts to

318 Some states encourage courts to consider the full context of a relationship in determining whether particular allegations justify relief. See, e.g., Cruz-Foster v. Foster, 597 A.2d 927, 930 (D.C. 1991) (holding that courts should be apprised of the entire mosaic of the parties' relationship, not just isolated incidents, when assessing whether good cause exists to extend a $\mathrm{CPO})$.

319 See supra Section I.D.

${ }^{320}$ As stated by a young woman to a United Kingdom working group on forced marriage: "A person knows when they are being forced into a marriage against their will-that must be the starting point." A CHOICE BY RIGHT, supra note 84, at 6. Adopting the petitioner's perspective has similarly been suggested as a means of overcoming challenges to defining "coercion" or "coercive control" as actionable qualifying conduct in protection orders statutes, given wide variations in the degree and subjective experience of control. GOODMARK, supra 
distinguish between arranged marriages and forced ones. To this end, FMPO statutes should make actionable any intentional course of conduct causing a petitioner to experience force to marry, with the intent inquiry requiring a finding that a respondent had a general intent to commit the acts that amount to force, not a specific intent to force a marriage. ${ }^{321}$

In the domestic violence context, Professor Jeffrey Baker has argued for the opposite approach. Professor Baker proposes that states expand qualifying conduct in civil protection order statutes to include (non-criminal) coercion, which is defined according to the goals behind a perpetrator's conduct. ${ }^{322}$ Professor Baker's approach is intended to avoid subjecting a petitioner to a potentially stigmatizing examination of the extent of her subordination. ${ }^{323}$ This aim is worthy. In the FMPO context, however, requiring courts to find that a respondent had a specific intent to force a child into a marriage would risk prioritizing the respondent's own perception of his or her actions over the lived experiences of the victim. Professor Baker's proposal appears to preclude relief in the domestic violence context if a perpetrator does not view his or her motivations in the manner ascribed. ${ }^{324}$ Professor Leigh Goodmark notes that although intent to control has been widely ascribed to perpetrators of abuse, findings in the psychological and social science fields suggest that both those inflicting and subjected to domestic abuse do not necessarily identify control as a motivating force in their experiences. ${ }^{325}$ This disconnect is likely to arise in the forced marriage context as well, as perpetrators of forced marriage reportedly often believe they are doing nothing wrong. ${ }^{326}$

note 119, at 48-49; Tamara L. Kuennen, Analyzing the Impact of Coercion on Domestic Violence Victims: How Much Is Too Much?, 22 BERKELEY J. GENDER, L. \& JuST. 2 , 11 (2007).

321 This proposed language builds from Professor Goodmark's proposed alternative construction of actionable non-criminal coercion as qualifying conduct in domestic violence protection order statutes. Professor Goodmark proposes to make actionable "any intentional course of action that causes a petitioner to experience a loss of liberty, freedom, or autonomy" and limiting examination of the perpetrator's intent to whether the conduct was intentional, regardless of its motivation. GoODMARK, supra note 119, at 50.

${ }^{322}$ Jeffrey R. Baker, Enjoining Coercion: Squaring Civil Protection Orders with the Reality of Domestic Abuse, 11 J. L. \& FAM. STUD. 35, 58 (2008).

323 Id. at 59.

${ }^{324}$ GOODMARK, supra note 119 , at 48 .

${ }^{325} \mathrm{Id}$.

326 Alanen, supra note 11, at 12; see also, e.g., Marriage or Rape?, NEwSWEEK (Dec. 15, 1996, 7:00 PM), http://www.newsweek.com/marriage-or-rape-175142 [https://perma.cc/G7

Y7-7FLU] (in case in which thirteen- and fourteen-year-old daughters were allegedly forced to marry substantially older men in Nebraska, which resulted in the conviction of the husbands for rape and charges against the parents for child abuse and contributing to the delinquency of a minor, the adults involved were reported to have believed they did nothing wrong). 


\section{Targeted Solutions}

Forced Marriage Protection Orders should be structured to encourage courts to order relief that addresses the specific circumstances facing the petitioner. Rather than mandate the inclusion of any particular remedies within FMPOs, statutes should follow the common domestic violence protection order model of listing possible remedies to help courts identify common needs. Such remedies should include provisions prohibiting a respondent from enabling or permitting a wedding to proceed, restricting travel, requiring the submission of a petitioner's passport to the court, prohibiting parents from applying for a passport for a child, ordering the return of an individual who has been taken abroad, limiting contact between the respondent and the petitioner, ordering a respondent to stay away from a petitioner, prohibiting coercive or isolative conduct, or mandating that a petitioner continue to attend school. ${ }^{327}$ To maximize FMPOs' agility to respond to a victim's particularized needs, statutes also should authorize courts to make any other orders appropriate to the resolution of the case. ${ }^{328}$ Maximizing the adaptability of FMPOs to the needs and interests of each petitioner and encouraging courts to approach FMPOs as an individually tailored remedy could help to encourage more petitioners to seek relief.

\section{Publicizing Relief}

Individuals facing forced marriages often do not know that civil legal protections might be available to them. ${ }^{329}$ Legal and social service professionals attempting to assist potential victims are also often unsure or unaware of the potential for civil protection orders to provide relief. ${ }^{330}$ The ambiguity of existing laws as applied to forced marriage and minor petitioners only amplifies this uncertainty. ${ }^{331}$ Uncertainty regarding the viability of protection orders to prevent forced marriage may discourage service providers from assisting potential victims to seek relief because of concerns about the likelihood of success, lack of organizational expertise, or alignment of the work with agency-mission or grant-funding mandates. ${ }^{332}$ Creating a specialized forced marriage protection order remedy (combined with a thoughtful public education campaign) would inform potential victims, service providers, and others who seek to help that legal protections exist, as well as convey the state's recognition of and commit-

${ }^{327}$ Landau, supra note 11, at 50; Alanen, supra note 11, at 12-13; CHERYL THOMAS ET AL., DeVEloping LegisLation on Violence Against WoMEN AND GiRls 378-79 (May 2011), http://www.endvawnow.org/uploads/modules/pdf/1355776748.pdf [https://perma.cc/YV9E$7 \mathrm{HLH}]$.

${ }^{328}$ GOODMAN \& EPSTEIN, supra note 118 , at 75.

${ }^{329}$ Swegman, Forced Child Marriage Case Scenarios for Lisa Martin, supra note 58.

${ }^{330} I d$.

${ }^{331} I d$.

${ }^{332} I d$. 
ment to redressing the problem, which could encourage grant funders and service organizations to expand their missions in turn.

\section{B. Evolution}

Many of the shortcomings of civil protection order statutes in the forced marriage context have been identified as undermining the efficacy of the remedy to redress domestic violence as well. ${ }^{333}$ Addressing these issues in the forced marriage context may permit states to test out new approaches on a smaller scale that could support the evolution of civil protection order statutes to a more victim-centered model.

\section{Moving Away from the Criminal Paradigm}

A number of scholars have noted that whereas social scientists have come to understand domestic abuse as an ongoing campaign of coercive control ${ }^{334}$ or intimate terrorism ${ }^{335}$ employed to dominate and entrap an intimate partner within the relationship, protection order statutes continue to define domestic violence by isolated acts of criminal conduct and physical violence. ${ }^{336}$ From a coercive control perspective, physical force represents one possible tool among many non-criminal, non-violent tactics, all of which are aimed at establishing control and domination over another individual. Physical violence may be a component of a campaign of coercive control, but it is not necessary. It is the broader, unified motivation of control and dominance that makes a relationship abusive, rather than the use of particular tactics. The focus on individual actions obscures the broader dynamic of the relationship and excludes from protection individuals who are abused, disempowered, and subjugated in their relationships but not through tactics that meet the legal standard. Centering court inquiries on isolated actions also inadvertently results in the issuance of orders against individuals who are primarily the targets of abuse within their relationships if they have used force or made threats upon occasion-whether to defend themselves or in the course of lashing out or asserting independence. ${ }^{337} \mathrm{In}$

333 GOODMAN \& EPSTEIN, supra note 118, at 80; GOODMARK, supra note 119, at 34-35; Johnson, supra note 201 , at 1111.

${ }^{334}$ Sociologist Evan Stark understands abuse as the employment of methods of coercion and control by men to entrap and dominate women in intimate relationships. EvAN STARK, Coercive Control: How Men Entrap Women in Personal Life (2007).

${ }^{335}$ Sociologist Michael Johnson defines intimate terrorism as a form of domestic violence in which a range of tactics are used to establish power and control over an intimate partner. Michael P. Johnson, A Typology of Domestic Violence: Intimate TerRoRism, Violent Resistance, AND SituATiOnal Couple Violence (2008).

${ }^{336}$ GOODMAn \& EPSTEIN, supra note 118, at 79; GOODMARK, supra note 119, at 40; Johnson, supra note 201, at 1111; Kuennen, supra note 320, at 20-21.

${ }^{337}$ See Leigh Goodmark, When Is a Battered Woman Not a Battered Woman? When She Fights Back, 20 YALE J. L. \& FEMINISM 75, 76 (2008). 
such cases, although an isolated act technically may satisfy the legal standard, issuance of a protection order does not advance the state's goal in combating domestic violence, and it may undermine that goal by converting a protection order into another weapon for a perpetrator to manipulate. ${ }^{338}$ The creation of an FMPO remedy provides an opportunity to build a framework that focuses the court's inquiry on the broader dynamic at play.

\section{Toward the Perspective of the Targeted}

Although protection order statutes were developed to advance the interests of individuals subjected to abuse, and the remedy has been recognized as the most victim-centered available ${ }^{339}$ the current structure of the protection order remedy can subordinate the petitioner's perspective and wishes. Defining domestic violence from a criminal law lens has focused protection order proceedings on the commission of particular acts rather than the total lived experience of the petitioner. Scholars have argued that the standardization of public and private systems' response to domestic violence cases has directed attention away from the particular circumstances of the individuals subjected to abuse. ${ }^{340}$ Such standardization manifests in the protection order context in limited definitions of qualifying "abuse"; limited, pre-defined remedies; and policies that mandate arrest and "no-drop" prosecution of domestic violence offensesincluding violation of a protection order. Moreover, a number of scholars have noted that the systemic response to domestic violence has prioritized separation and safety at the expense of meeting the self-identified needs of those subjected to abuse, including the need to stay connected with their communities and those with whom they have intimate and familial relationships. ${ }^{341}$ The creation of

338 See Murphy v. Okeke, 951 A.2d 783, 785-86 (D.C. 2008) (overturning a lower court order entering mutual civil protection orders against a petitioner and respondent upon a finding that the respondent was the primary aggressor, and holding that a court is not obligated to issue a civil protection order just because it finds that a qualifying offense occurred, instead, civil protection orders only should be issued when doing so advances the purpose of the Intrafamily Offenses Act-to protect victims of abuse).

339 Jane K. Stoever, Freedom from Violence: Using the Stages of Change Model to Realize the Promise of Civil Protection Orders, 72 OHIO ST. L.J. 303, 307 (2011).

${ }^{340}$ Goodman \& EPSTEIn, supra note 118, at 91; Laurie S. Kohn, The Justice System and Domestic Violence: Engaging the Case but Divorcing the Victim, 32 N.Y.U. REV. L. \& Soc. CHANGE 191, 194 (2008).

${ }^{341}$ GOODMAN \& EPSTEIn, supra note 118, at 96; SusAn SCHECTER, EXPANDING SOLUTIONS FOR DOMESTiC Violence AND Poverty: What BAtTered WoMen With Abused Children NeED FROM THEIR AdVOCATES 7, 11 (2000); Donna Coker, Shifting Power for Battered Women: Law, Material Resources, and Poor Women of Color, 33 U.C. DAVIS L. REV. 1009, 1019 (2000); Goldfarb, supra note 119, at 1488-89; Leigh Goodmark, Law Is the Answer? Do We Know that for Sure?: Questioning the Efficacy of Legal Interventions for Battered Women, 23 ST. LouIs U. Pub. L. Rev. 7, 19 (2004); Margaret E. Johnson, Changing Course in the Anti-Domestic Violence Legal Movement: From Safety to Security, 60 VILL. L. ReV. 145, 146-47 (2015). 
FMPOs offers the chance to create an injunctive remedy that centers the court's inquiry and allocation of remedies on a petitioner's experience and identified needs.

\section{Toward a Presumption of Access}

Protection order statutes undermine their efficacy for minors by excluding them from and restricting or failing to address the circumstances under which minors can access relief. This is troubling, as minors are at significant risk for abuse and frequently reluctant to seek adult intervention and support. ${ }^{342}$ In practice, ambiguity or silence regarding minors in protection order statutes may result in their exclusion from remedies, since courts and service providers who are uncertain about minors' eligibility for relief may turn minors away. ${ }^{343}$ Forced Marriage Protection Orders offer an opportunity to craft a remedy that encourages minors to seek legal protection by explicitly extending standing to all minors, and legal capacity to older minors to represent their own interests, should they choose to do so. To ensure that minors who want the assistance of a supportive adult in court proceedings can rely upon it, FMPOs also should grant standing to a broadly construed class of adult representatives to seek orders on behalf of minors. ${ }^{344}$ To ensure that minors' perspectives and wishes remain the focus in cases where adults represent minors' interests, courts should be required to solicit the minor petitioner's perspective on whether an FMPO should be issued and what remedies it should contain. ${ }^{345}$ When older minors appear in court without adult representatives, courts should be authorized to appoint attorneys to represent minors' expressed interests in the proceeding. ${ }^{346}$ Empowering adolescents with the autonomy to control the pursuit of civil remedies to prevent their own forced marriages not only could encourage minors to seek relief but also would advance state policies that enable minors to act in their own interests to protect their safety, health, and welfare. ${ }^{347}$

${ }^{342}$ Martin, supra note 105, at 459-60.

${ }^{343} I d$. at 508.

344 See, e.g., D.C. CODE $§ 16-1005(a)(1)-(3)$ (2018) (permitting protection orders to be filed on behalf of minor petitioners by "a parent, guardian, custodian, or other appropriate adult").

345 See, e.g., D.C. CODE § 16-1005(a)(1)-(3) (2018) (" [I]f a parent, guardian, custodian, or other appropriate adult has petitioned for civil protection on behalf of a minor petitioner 12 years of age or older, the court shall consider the expressed wishes of the minor petitioner in deciding whether to issue an order pursuant to this section and in determining the contents of such an order."). This approach also ensures that orders are sought on behalf of minors for reasons consistent with the purpose of the remedy. See, e.g., Claver v. Wilbur, 280 S.W.3d 570, 570, 573 (Ark. Ct. App. 2008) (dismissing a civil protection order that a mother obtained on behalf of her sixteen-year-old daughter against the daughter's boyfriend on the grounds that " $[\mathrm{t}]$ he mere fact that [the minor's] parents do not like appellant was not a proper ground upon which to issue an order of protection").

${ }^{346}$ Martin, supra note 105 , at 500.

347 Brustin, supra note 243 , at 351 (highlighting the continuing discussion in state legislatures about when adolescents ought to be able to act autonomously); Jeruss, supra note 262, 


\section{Circumspection}

Several possible criticisms could be levied against the creation of forced marriage protection orders.

\section{Feasibility}

Recent expansions of the civil protection order remedy to encompass claims against stalking, harassment, and common partners has inundated some domestic violence courtrooms with cases involving mundane disputes between neighbors and love triangle jealousies that lack the coercive dynamics and intimate bonds that civil protection orders were intended to navigate. ${ }^{348}$ These expansions and their aftermath may have created protection order fatigue and could inspire a resistance to creating a new category of injunctive relief, particularly if at least some victims of forced marriage could seek relief under existing protection order statutes.

These experiences or general "floodgates" concerns should not discourage enactment of forced marriage-specific relief. As both a form of violence in its own right and a precursor to physical and sexual abuse, forced marriage should be a problem of serious concern to states, and falls squarely within the range of problems the protection order remedy was created to address. Although anecdotal evidence and the limited existing quantitative data point to forced marriage as a persistent problem, there are no indications that it is of a magnitude that would overwhelm the courts. Investments in effective mechanisms to prevent forced marriage can mitigate and avoid significant harms to individuals and future offspring, and associated costs to states.

\section{Enforceability}

Civil protection orders have proved an effective remedy, in part, because of their robust enforceability. Protection orders generally are enforceable through

at 895 (detailing the passage of mature-minor statutes in recent years and noting that "[a]ll of these statutes have converged on the idea that there are certain areas where minors need protection from harm. In these areas, minors are granted the rights to make important decisions without notifying their parents"); see Caitlin M. Cullitan, Please Don't Tell My Mom! A Minor's Right to Informational Privacy, 40 J.L. \& EDUC. 417, 444 (2011) (observing that in the context of healthcare, teens are deterred from seeking treatment for sexually transmitted infections by fear of disclosure, leading states to eliminate parental-consent requirements for such treatment); Rhonda Gay Hartman, Adolescent Decisional Autonomy for Medical Care: Physician Perceptions and Practices, 8 U. CHI. L. SCH. RoundTABle 87, 92-93 (2001) (discussing how state legislatures have lowered or eliminated the age at which teens may consent to treatment in an effort to encourage teens to access mental-health services); Susan D. Hawkins, Note, Protecting the Rights and Interests of Competent Minors in Litigated Medical Treatment Disputes, 64 FordHAM L. REv. 2075, 2123 (1996) (explaining that matureminor medical statutes encourage minors to seek medical care that they would not if parental consent were needed).

348 See, e.g., D.C.CODE ANN. § 16-1001 (2018). 
civil and criminal contempt proceedings, and violations of protection orders also often constitute a distinct criminal offense. ${ }^{349}$ The full faith and credit requirement of the federal Violence Against Women Act ensures that protection orders are enforceable across state lines. ${ }^{350}$

In light of the common resistance to criminal prosecution of those facing forced marriages and the historical ineffectiveness of criminal laws at penalizing forced marriage, states should think carefully about whether to similarly criminalize violations of forced marriage protection orders. If FMPO violations are criminalized, such offenses should not be subject to mandatory arrest and no drop prosecution policies, which could strongly deter use of the FMPO remedy, especially among immigrant communities.

It might be argued that failing to criminalize FMPO violations would set up FMPOs as a "lesser" form of protection order, thereby sending the message that forced marriage is a "lesser" form of domestic abuse. ${ }^{351}$ Others might object that vesting control over enforcement in the petitioner leaves the petitioner vulnerable to a respondent's attempts to persuade or coerce her to dismiss enforcement proceedings. ${ }^{352}$ Some might also question the efficacy of protection orders if petitioners have sole enforcement discretion and a reluctance to exercise that right. ${ }^{353}$ Yet, the history of forced marriage prosecution in the U.S. and the U.K. to date suggests that criminalization efforts may have more symbolic than practical value. ${ }^{354}$ Moreover, in light of the common need for emergency

349 Protection Order Violations Matrix, Nat'l Ctr. on Protection Orders \& Full FAITH \& CREDIT (2014), http://www.bwjp.org/assets/documents/pdfs/protection_order_viola tions_matrix.pdf [https://perma.cc/B7TD-PRAU]; David M. Zlotnick, Empowering the Battered Woman: The Use of Criminal Contempt Sanctions to Enforce Civil Protection Orders, 56 OHIO ST.L.J. 1153, 1194 (1995); Klein \& Orloff, supra note 115, at 1101-02.

35018 U.S.C. $\$ 2265$ (2012). See generally Full FAITH AND CREDIT FOR PRotection Orders: AsSisting Survivors With ENFORCEMENT ACROSS JuRISDictional LiNES, NAT'L CTR. ON PROTECTION ORDERS \& FULl FAITH \& CREDIT, http://www.bwjp.org/assets/docu ments/pdfs/ffc_advocate_guide.pdf [https://perma.cc/ZHR3-UYAF] [Hereinafter FULL FAITH AND CREDIT FOR PROTECTION ORDERS].

${ }^{351} C f$. Ruth GafFNey-Rhys, RePORT fOr the OfFice of the High COMmissioner for Human Rights: Forced MarRiage in England and Wales: Challenges, ACHIEVEMENTS, BEST PRACTICES AND IMPLEMENTATION GAPS (2013).

352 A Wrong Not a Right, supra note 16; Home OfFice, Forced Marriage Consultation, (2011) [hereinafter Forced Marriage Consultation]; Home OfFice, Forced Marriage: A CONSUltation-Summary OF Responses (2012); Robert F. Friedman, Protecting Victims from Themselves, but Not Necessarily from Abusers: Issuing a NoContact Order over the Objection of the Victim-Spouse, 19 WM. \& MARY BILL RTS. J. 235 (2010).

353 ForCed Marriage Consultation, supra note 352, at 6 (noting that from Nov. 2008 to Dec. 2011 only five FMPO breaches reported, and only one civil contempt proceeding was brought for a violation).

354 The Legal Framework on Forced Marriages in the United Kingdom and SOME ReCOMmendations, SAVE Your Rights 10 (2011), http://www.saveyourrights.org/wpcontent/uploads/2014/09/SYR-REPORT-as-printed.pdf [https://perma.cc/JVD3-74ZX] (noting that need for cooperation of forced marriage victim may make value of forced marriage 
intervention, such as when forced marriage is imminent, it is critical that preventive policies are designed to encourage individuals to come forward and seek assistance. Separating FMPOs from possible criminal penalties eliminates a possible barrier to seeking relief. Finally, electing not to criminalize FMPO violations would not immunize perpetrators from criminal penalties. Even if FMPO violations themselves are not criminalized, any violation that constitutes another criminal offense, such as assault, threats, or stalking, would be grounds for prosecution in its own right.

Furthermore, to ensure FMPOs have a deterrent effect on respondents, FMPOs should be enforceable through criminal and civil contempt proceedings initiated by the petitioner. The Violence Against Women Act's definition of "protection" order is sufficiently broad that its full faith and credit provisions should encompass FMPOs, and thereby ensure that FMPO petitioners remain protected when they cross state lines. ${ }^{355}$

\section{Desirability}

Some might also object that the legal system should not be looked to as a primary solution for forced marriage. A number of scholars have argued that "overreliance on the legal system has stunted the development" of other means of addressing the problem. ${ }^{356} \mathrm{~A}$ similar emphasis on developing effective legal interventions may funnel resources away from the development of creative non-legal interventions. ${ }^{357}$

It is also not clear whether those who could be eligible for FMPOs would pursue them in significant numbers. During the first thirty months when FMPOs were available in the United Kingdom, only 339 FMPOs were granted,

criminal offense, like the female genital mutilation criminal offense, of greater symbolic than practical value).

35518 U.S.C. $\$ 2266(5)(A)(2012)$ ("protection order includes . . any injunction, restraining order, or any other order issued by a civil or criminal court for the purpose of preventing violent or threatening acts or harassment against, sexual violence, or contact or communication with or physical proximity to, another person, including any temporary or final order issued by a civil or criminal court whether obtained by filing an independent action or as a pendente lite order in another proceeding so long as any civil or criminal order was issued in response to a complaint, petition, or motion filed by or on behalf of a person seeking protection. ..."); 18 U.S.C. $\$ 2265$ (a) (2012) (“Any protection order issued that is consistent with subsection (b) of this section by the court of one State, Indian tribe, or territory (the issuing State, Indian tribe, or territory) shall be accorded full faith and credit by the court of another State, Indian tribe, or territory (the enforcing State, Indian tribe, or territory) and enforced by the court and law enforcement personnel of the other State, Indian tribal government or Territory as if it were the order of the enforcing State or tribe."). See generally FULL FAITH AND CREDIT FOR PROTECTION ORDERS, supra note 350 , at 3.

356 Goodmark, supra note 119, at 6; see also GoOdMAn \& EPSTEIN, supra note 118, at 74. Professor Margaret Johnson has argued that domestic violence interventions also have been dominated by a focus on short-term safety, as defined by the state, to the detriment of the long-term security of individuals subjected to abuse. Johnson, supra note 341, at 165 .

357 Johnson, supra note 341, at 157. 
despite estimates that 5,000 to 8,000 forced marriages occur and the government's Forced Marriage Unit fields approximately 1,700 calls for assistance annually. ${ }^{358}$ Yet, the number of orders sought far exceeded initial expectations that "there would be between 5 and 50 application a year." 359 The same concerns about harming or bringing shame upon family members that make criminal intervention undesirable might deter those facing forced marriages from approaching the legal system under any circumstances. Reluctance to approach the justice system may be amplified for members of immigrant communities in the United States as a result of recent policies promoting enforcement operations. ${ }^{360}$ Finally, some might be concerned that creating policies to address forced marriage could stigmatize communities in which forced marriage is a problem, in some cases compounding existing challenges faced by religious and cultural minorities. ${ }^{361}$

These are important concerns but none should deter the creation of FMPOs. At present, no readily accessible remedy exists that can be relied upon to prevent a forced marriage. Only a small number of states enable intervention into a forced marriage where the coercion at play has not manifested in acts or threats of physical violence. Thus, the establishment of an FMPO remedy creates a benefit for those facing forced marriage no matter how infrequently the remedy is used, because it will offer legal relief to individuals who otherwise may have no viable legal remedy. The likelihood that the remedy may be infrequently used brings the potential benefit of not imposing a significant additional burden on court resources.

To encourage use of the remedy by those who could benefit, states should undertake education campaigns to inform the community about FMPOstaking care to frame the problem across a range of contexts - and simultaneously raise awareness about the problem of forced marriage and the rights of individuals to choose their own spouses. Community organizations could also part-

358 ForCed MARriage CONSUltation, supra note 352, at 6; GAFFNEY-Rhys, supra note 351.

359 Teertha Gupta \& Khatun Sapnara, The Law, the Courts, and Their Effectiveness, in Forced Marriage, Introducing a Social Justice AND Human Rights Perspective 159 (Aisha K. Gill \& Sundari Anitha eds. 2011) ("In part, the [Forced Marriage Protection] Act was intended to have symbolic as much as practical force (i.e. a deterrent effect) in order to raise awareness.").

360 Tom Dart, Fearing Deportation, Undocumented Immigrants Wary of Reporting Crimes, GUARDIAN (Mar. 23, 2017, 6:30 PM), https://www.theguardian.com/us-news/2017/mar/23/ undocumented-immigrants-wary-report-crimes-deportation [https://perma.cc/2LUA-FQD5]; Jennifer Medina, Too Scared to Report Sexual Abuse. The Fear: Deportation, N.Y. TIMES (Apr. 30, 2017), https://www.nytimes.com/2017/04/30/us/immigrants-deportation-sexualabuse.html [https://perma.cc/R2E2-DPWM]; Maya Rhodan, Deportation Fears Silence Some Domestic Violence Victims, TIME (May 30, 2017), http://www.time.com/4798422/ domestic-violence-deportation-immigration [https://perma.cc/HVE5-CCYU].

361 A CHOICE BY RIGHT, supra note 84, at 12 ("The Working Group is clear that the issue of forced marriage should not be used to stigmatise any community."). 
ner with community members to organize around the problem and identify common needs and workable interventions. Rather than relying on FMPOs as a one-size-fits-all solution, state governments and private foundations should invest in research to better understand the scope of the problem and the needs of those subjected to it, and should dedicate funding to programs committed to developing creative responses to address the needs identified. ${ }^{362}$

\section{CONCLUSION}

Forced marriage is a serious form of violence that the United States is currently failing to address. Yet, its widespread existence should be a call to political action. Given the enduring harms suffered by those forced into marriages and the challenges of securing the return of persons taken abroad against their will, efforts to combat the problem should prioritize prevention. Civil protection orders provide the best opportunity for relief under existing laws, and they are an appropriate and workable remedy for some facing forced marriage today. But, the general viability of civil protection orders to prevent forced marriage varies widely across states, particularly for minors. Adults being coerced by parents, other relatives, or household members through acts and threats of physical violence, stalking, or harassment are best positioned to secure relief through civil protection orders. Minors who are being coerced through emotional, psychological, and financial means as well as those being coerced by intended spouses or other third parties face a harder road and may be excluded from the remedy in many states.

States must recognize forced marriage itself as the harm to be prevented and combatted. The creation of specialized forced marriage protection orders would make legal protection more accessible and responsive to the needs of those facing forced marriages. Moreover, taking this step offers states the opportunity to implement lessons learned in the domestic violence context and refine the protection order remedy to redress past concerns. To maximize their utility to prevent forced marriage, FMPOs should focus the legal inquiry on the experience of the petitioner, define actionable harm according to the dynamics of the problem (rather than the criminal code), accord minors a clear path to legal relief, and grant courts the latitude to order creative solutions. Legal remedies are a last resort for those facing forced marriages and should not be relied upon as an isolated strategy to address the problem. Government and private resources should be devoted to studying the extent and nature of the problem and understanding the needs and interventions desired by those facing it. Such

${ }^{362}$ Lack of information about the problem of forced marriage is an obstacle to an effective response to the problem in the United States. The U.K. previously faced this same challenge. Id. ("The Working Group has found that there is a lack of reliable data on the cases of forced marriage, and that this lack of information has been a barrier to: recognition of the problem, getting commitment to tackling it, securing the right skills and resources to take effective action, [and] planning the provision of services for victims."). 
data along with collaborative efforts with impacted communities should guide the development of additional preventive strategies.

It was not too long ago that all fifty states created civil protection orders to prevent and intervene in domestic abuse because existing remedies were an incomplete fit to address the problem. Today, the emergence of another significant threat to individual autonomy, health, and well-being calls for a similar, unified state response and a new generation of protection orders targeted to restrain forced marriage. 


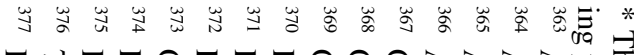

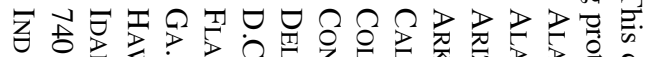

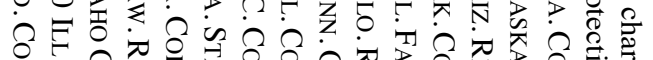

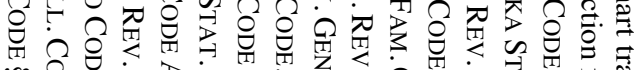

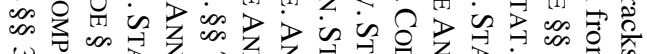

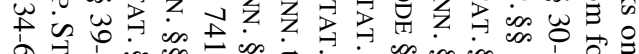

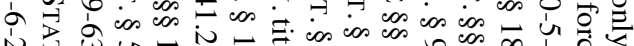

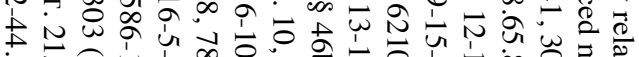

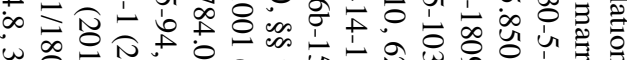
w。ㄱㅇㅇ.

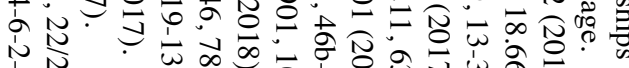

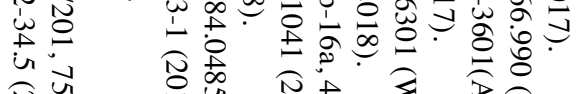

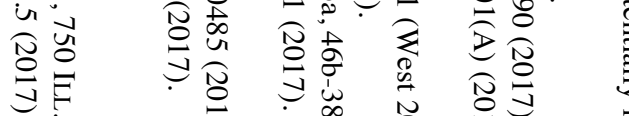

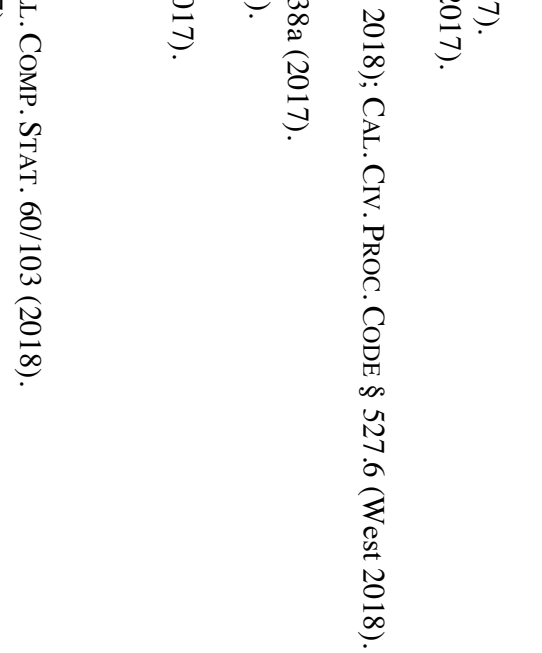
(1)

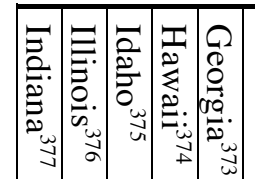
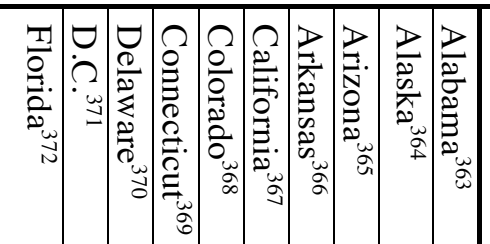

$\stackrel{*}{\stackrel{*}{*}}$

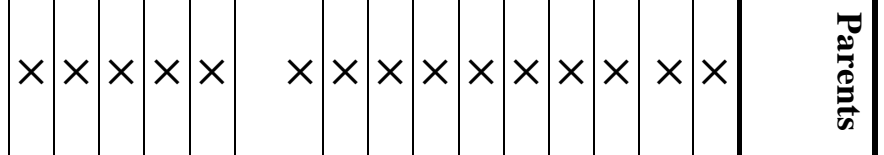

$x \times x \times x \quad x \times x \times x \times x \times x \times$

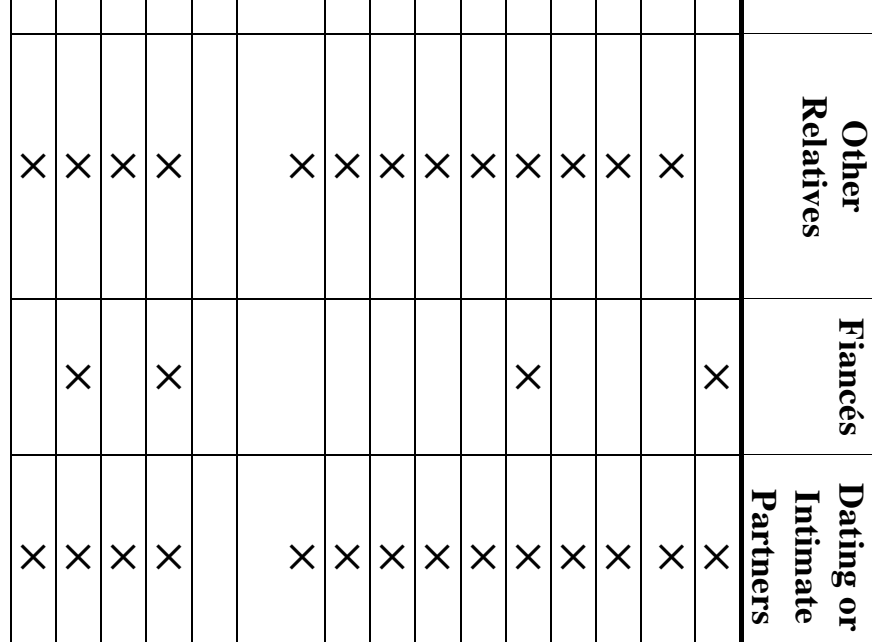

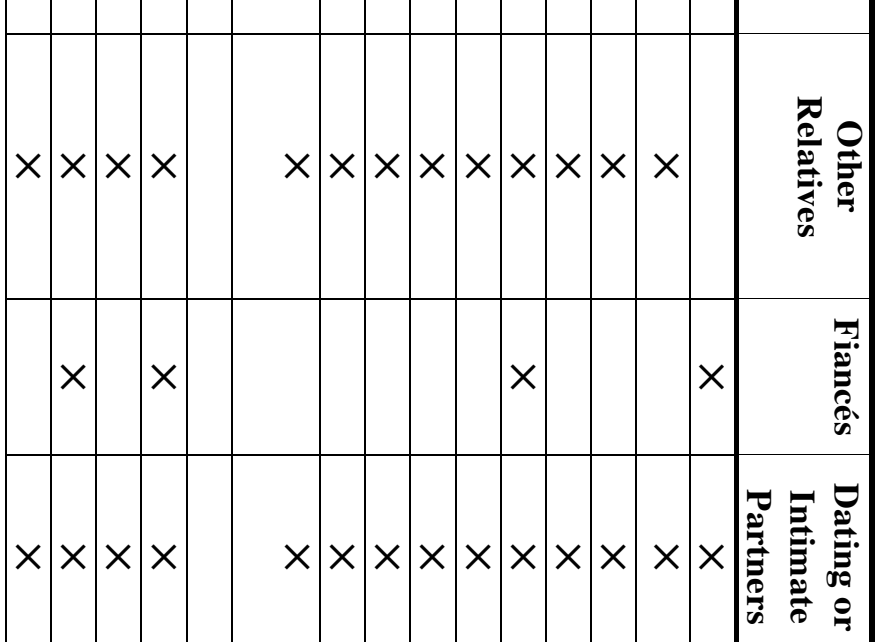
$x \times \times \quad \times \times \times \times \times \times \times \times$

$x \times x \times x \quad x \times x \quad x$ ?

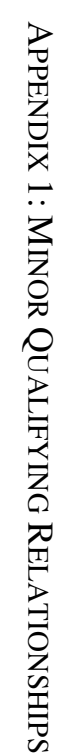

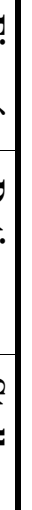

政

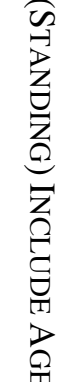

.

西




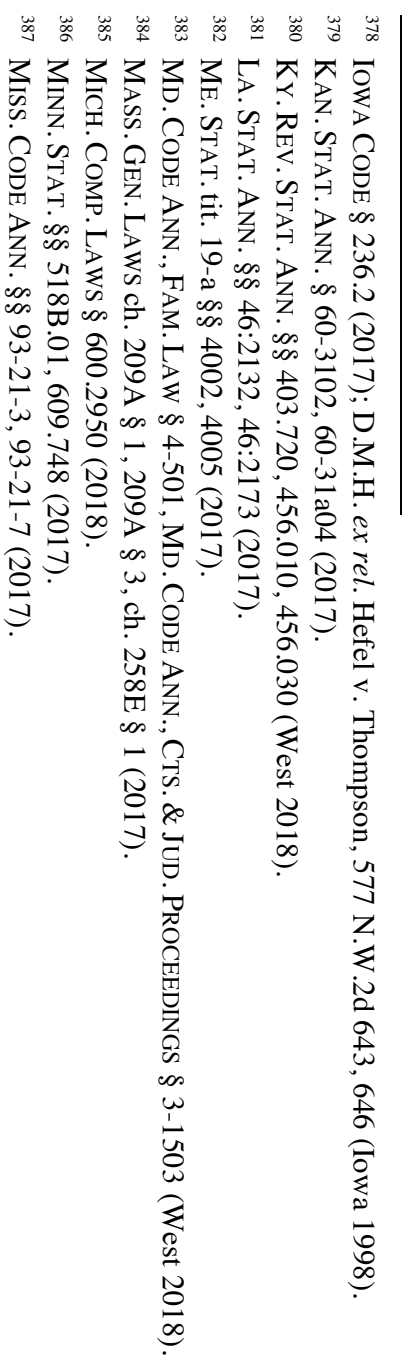

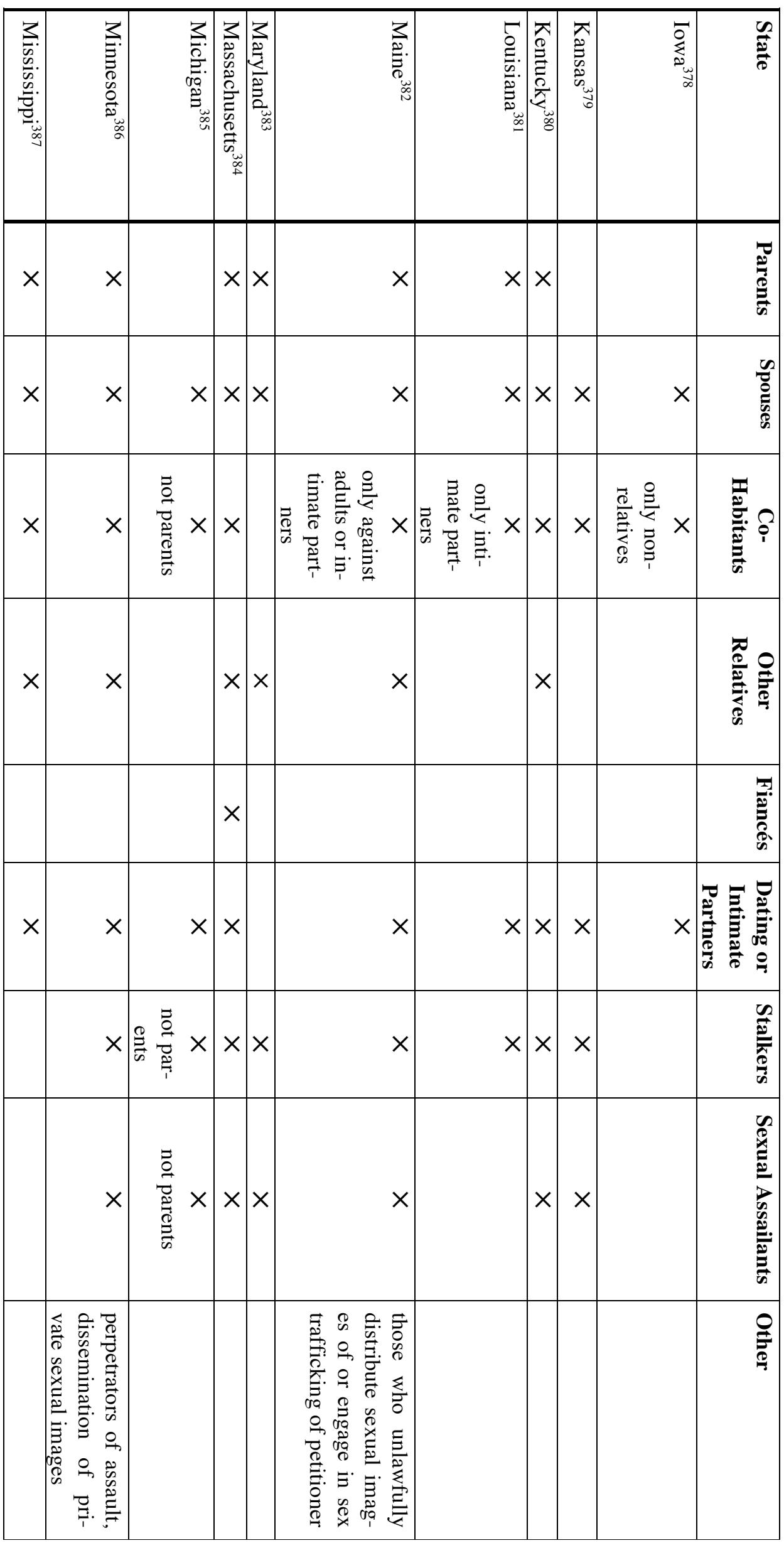




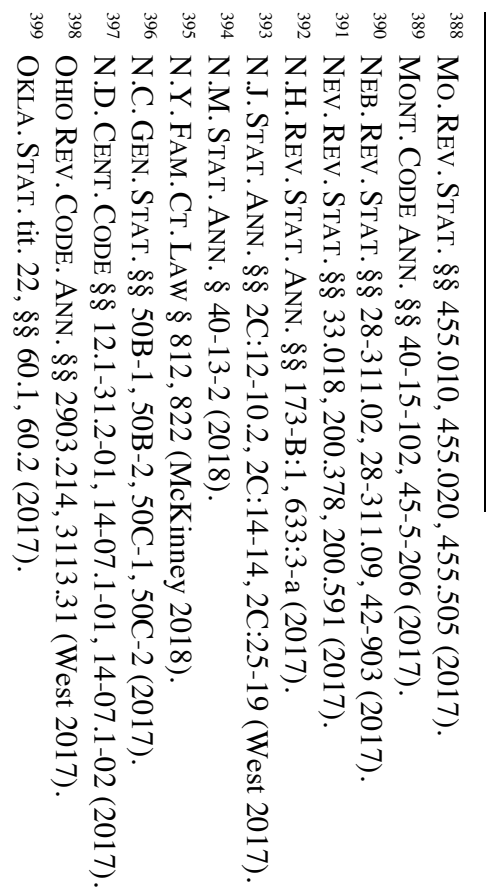

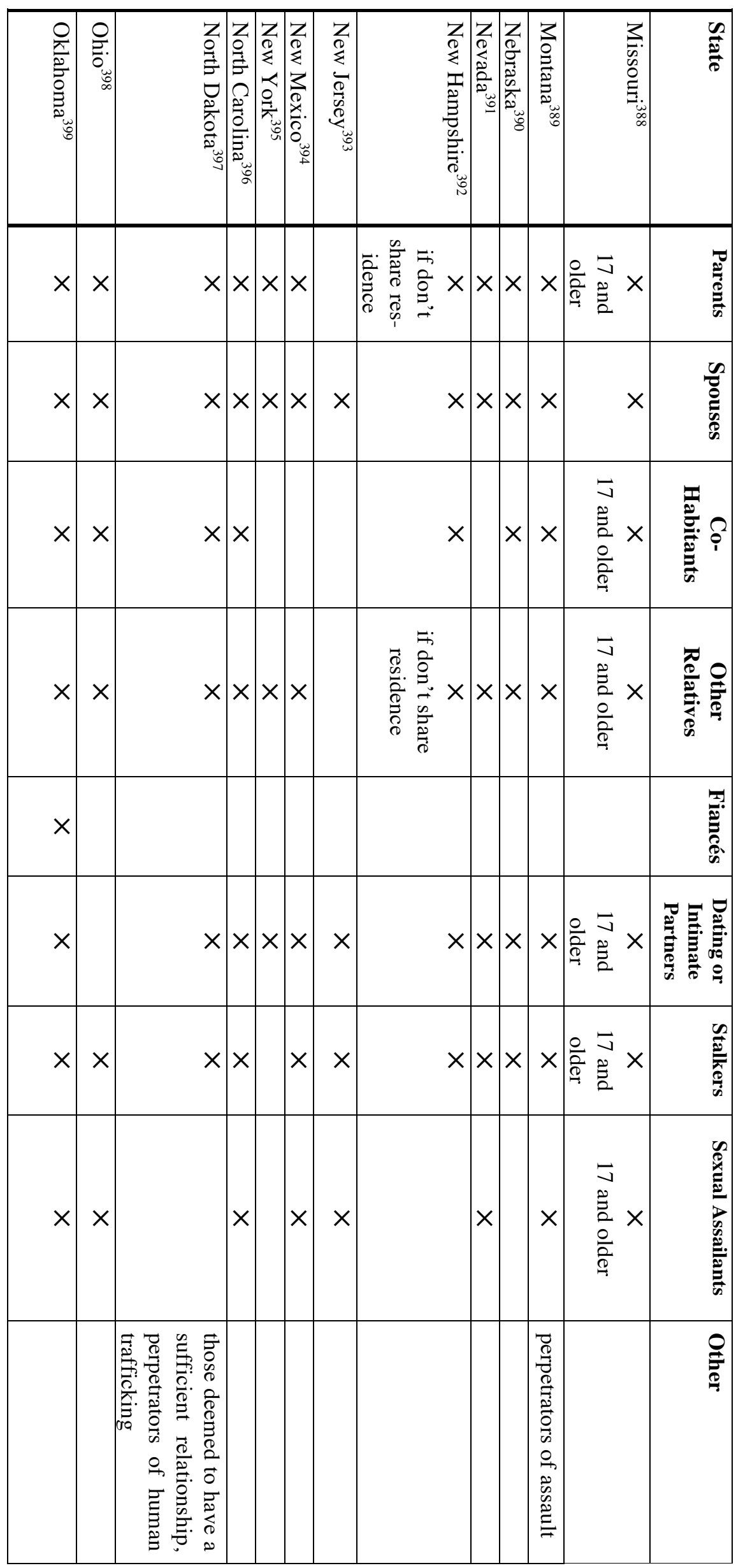



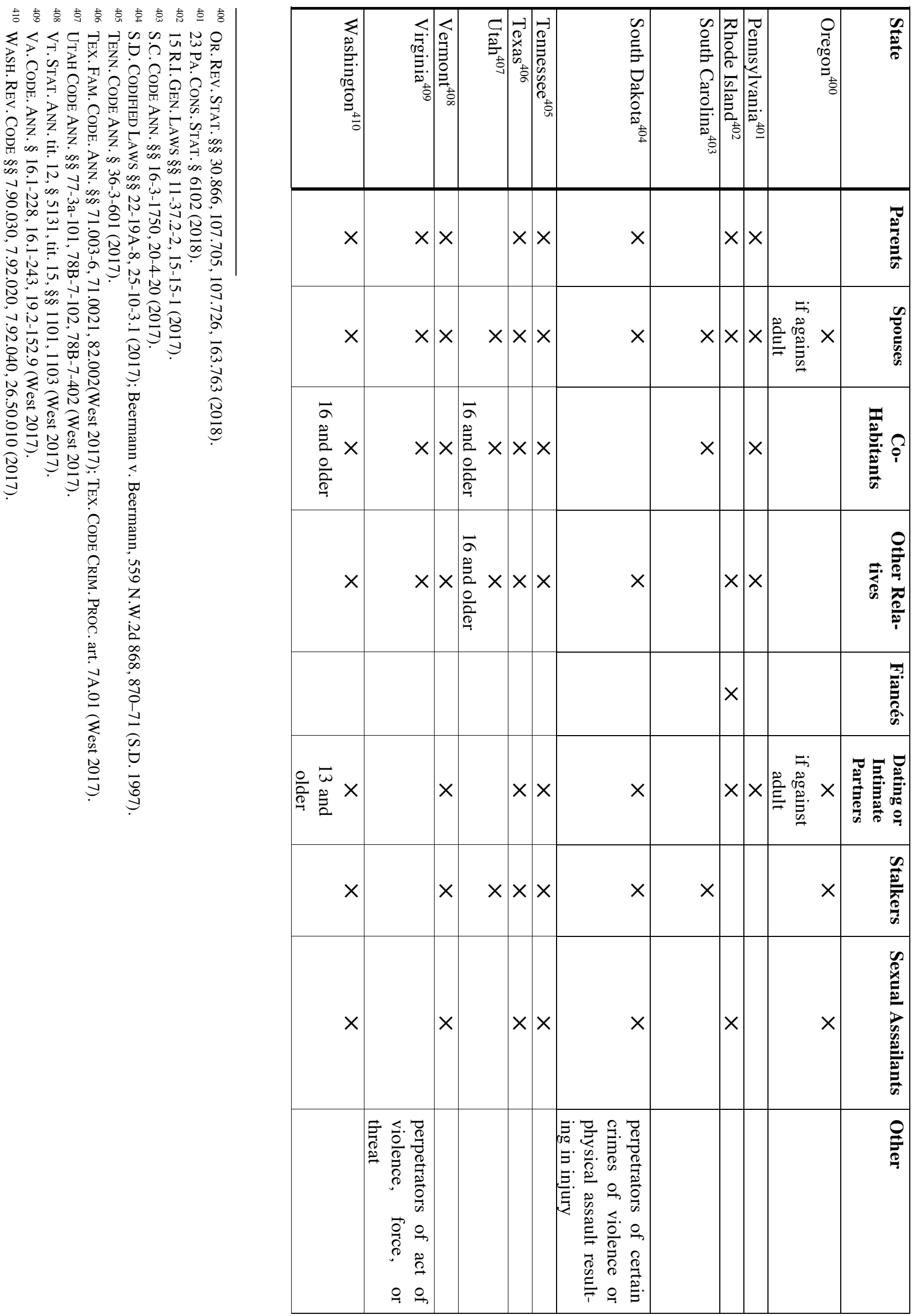

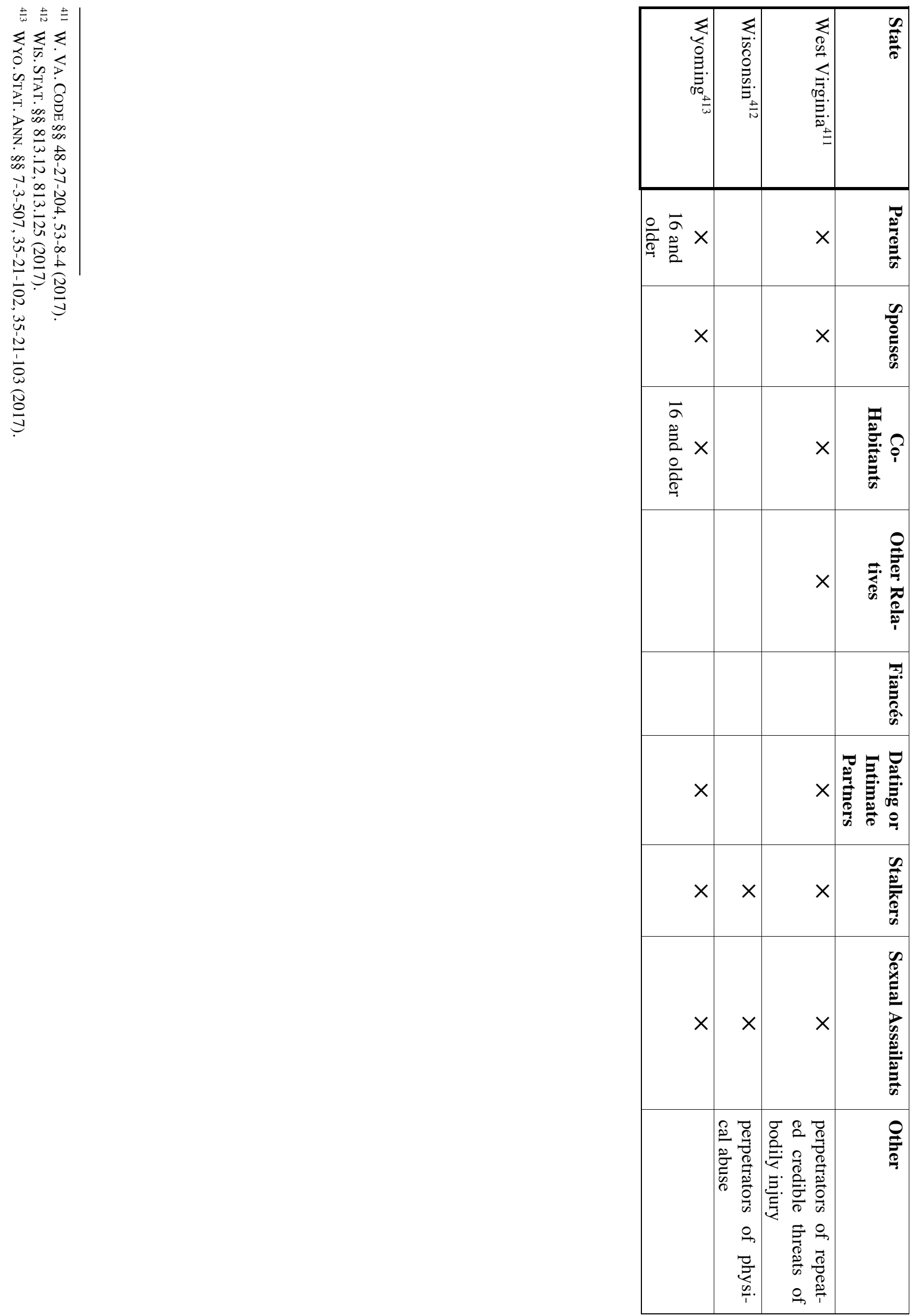


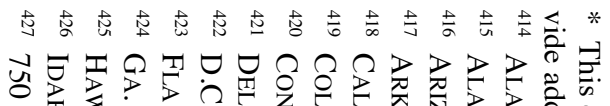

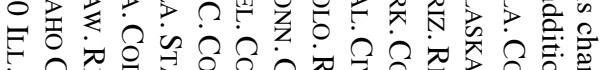

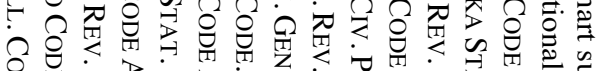

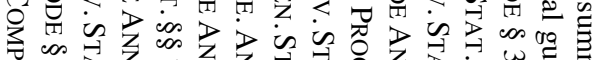

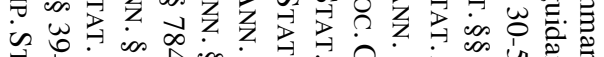

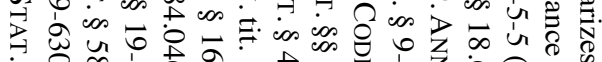

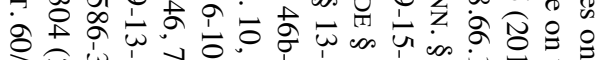

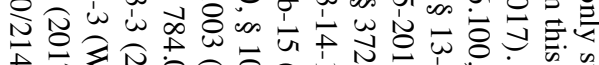

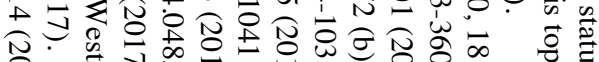

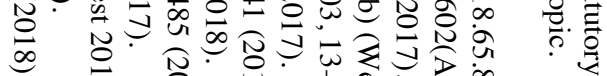

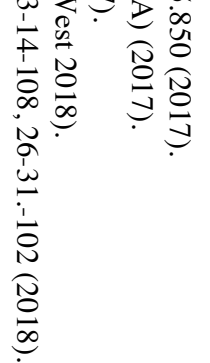

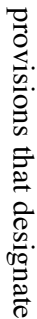
总

$\frac{\vec{\pi}}{\pi}$

馆

苨

全

要

ڤั)

$\stackrel{\vec{F}}{\stackrel{\vec{*}}{*}}$

足

華

$\frac{\overrightarrow{0}}{\mathrm{~s}}$.

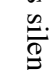

o

E.

कृ

छ

害

离

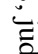

을.

(⿻)

$\frac{8}{8}$

这

䛎

8

范

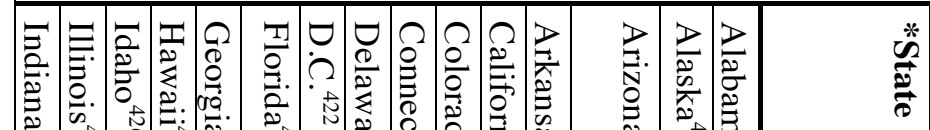
$\underset{\infty}{+}$ 志

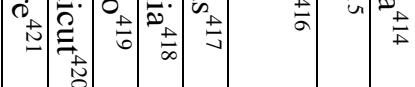

$\times \quad \times \times \quad \times \times \times \times \times \times \times \times \times \quad \times \quad \times \quad$

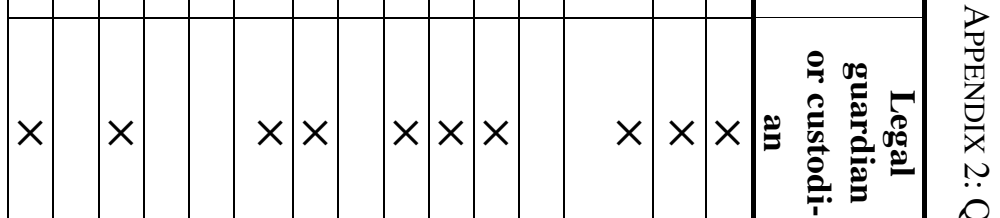
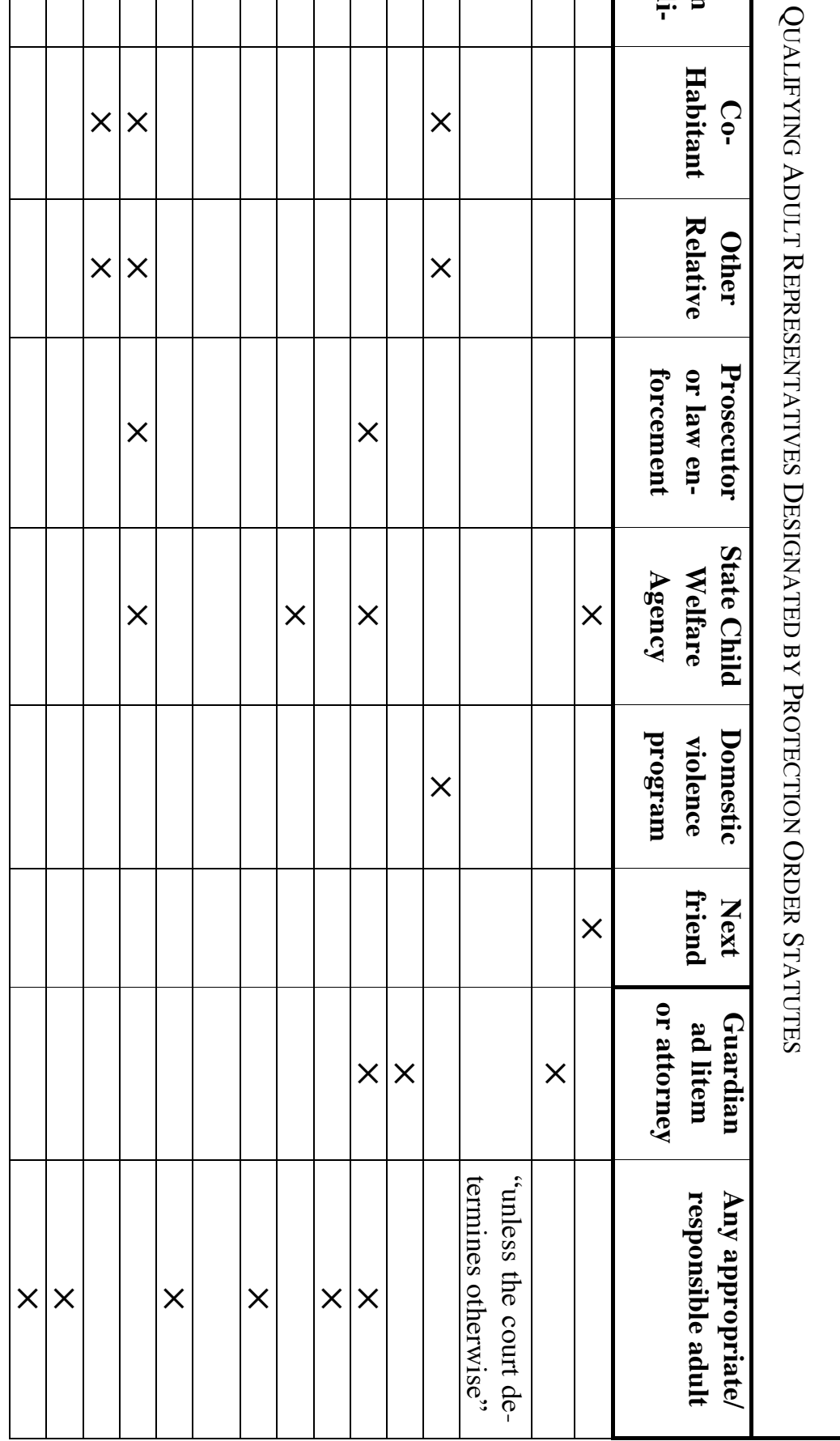


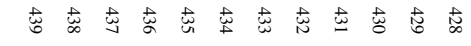

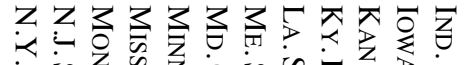
is n

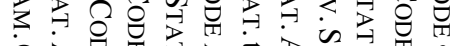

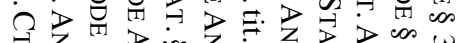

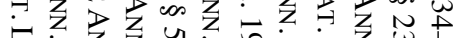
$5 \cos \}$

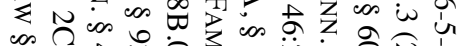

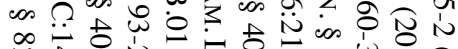

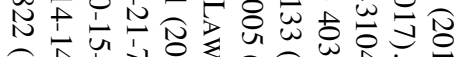

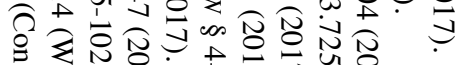
\&

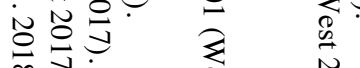

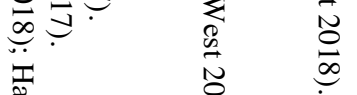
壱

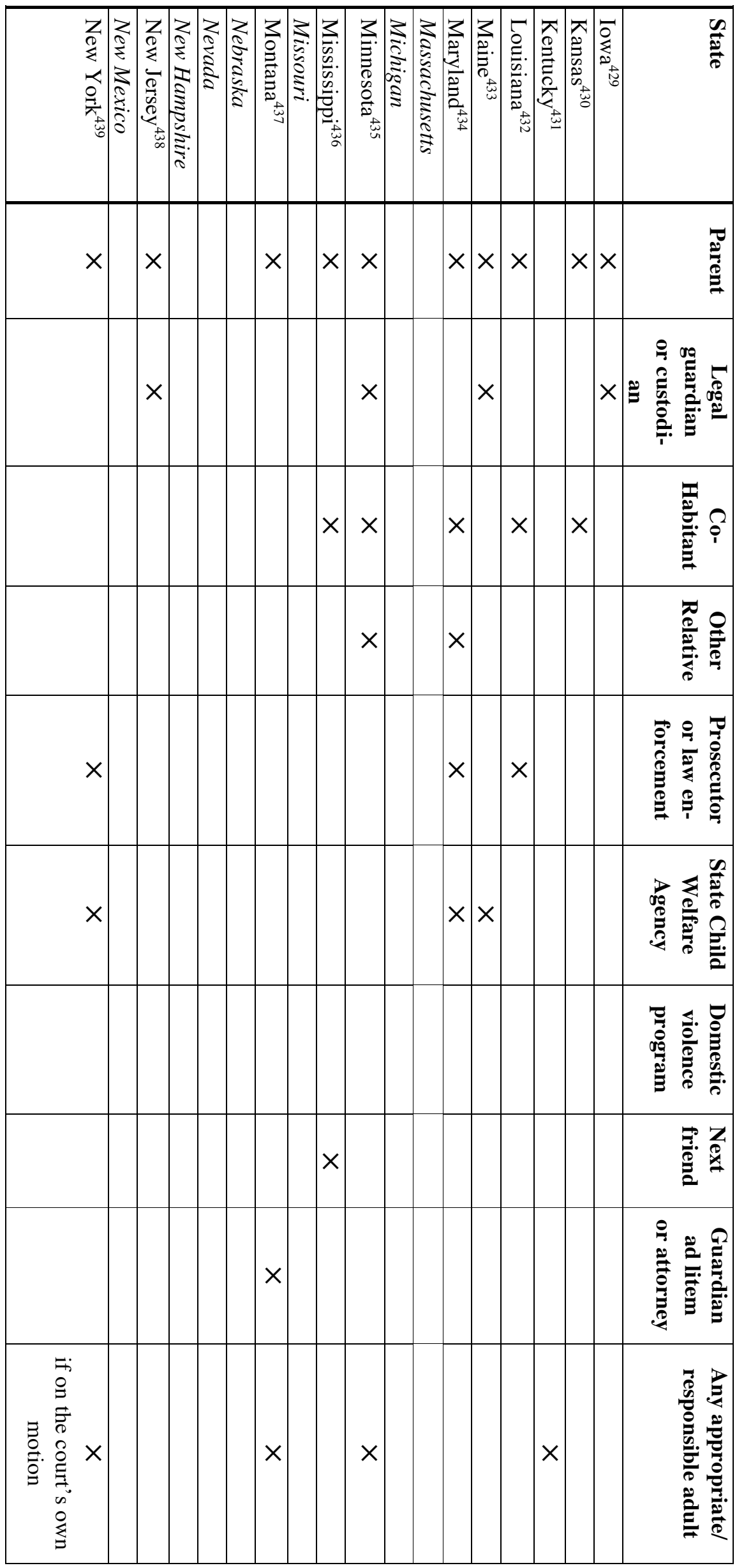




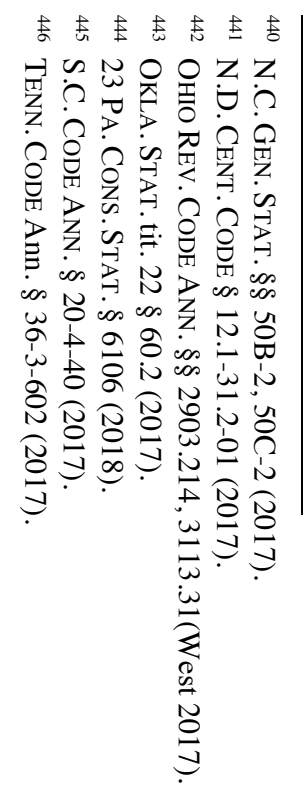

\begin{tabular}{|c|c|c|c|c|c|c|c|c|c|c|}
\hline 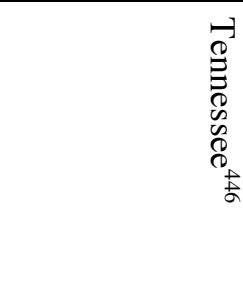 & 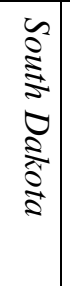 & 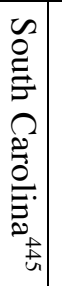 & 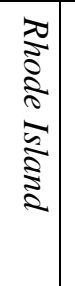 & 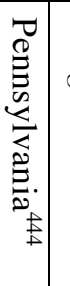 & 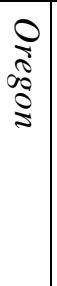 & 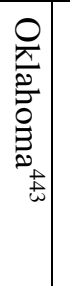 & 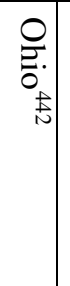 & 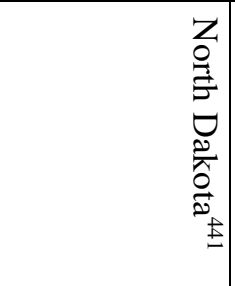 & 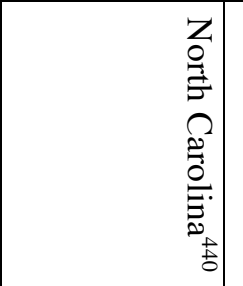 & 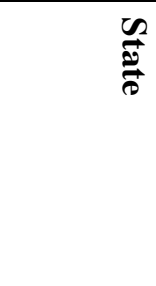 \\
\hline$x$ & & & & $x$ & & $x$ & $x$ & 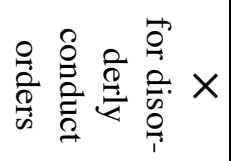 & 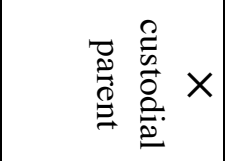 & 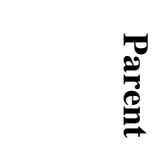 \\
\hline$x$ & & & & & & & & 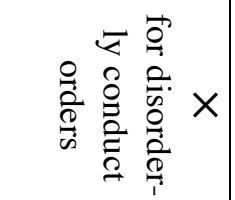 & $\times$ & 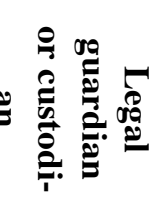 \\
\hline & & $x$ & & $x$ & & $\times$ & $x$ & & $x$ & ? \\
\hline & & & & & & $x$ & $x$ & & & 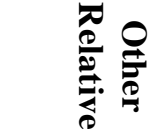 \\
\hline & & & & & & & & & & 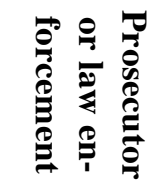 \\
\hline$x$ & & & & & & & & & & 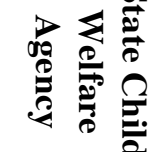 \\
\hline 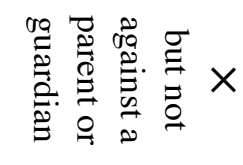 & & & & & & & & & & 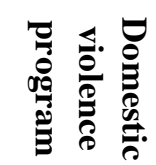 \\
\hline & & & & & & & & $\times$ & & 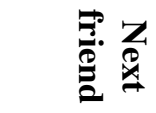 \\
\hline$x$ & & & & $x$ & & & & & & 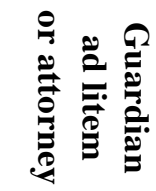 \\
\hline & & & & & & & & & 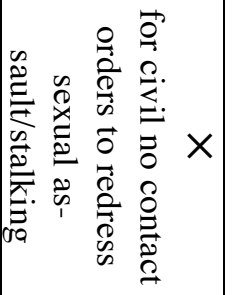 & 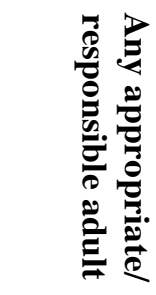 \\
\hline
\end{tabular}




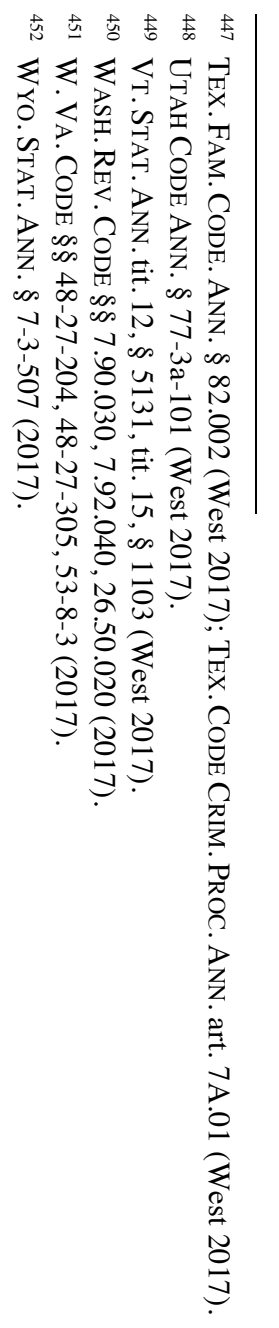

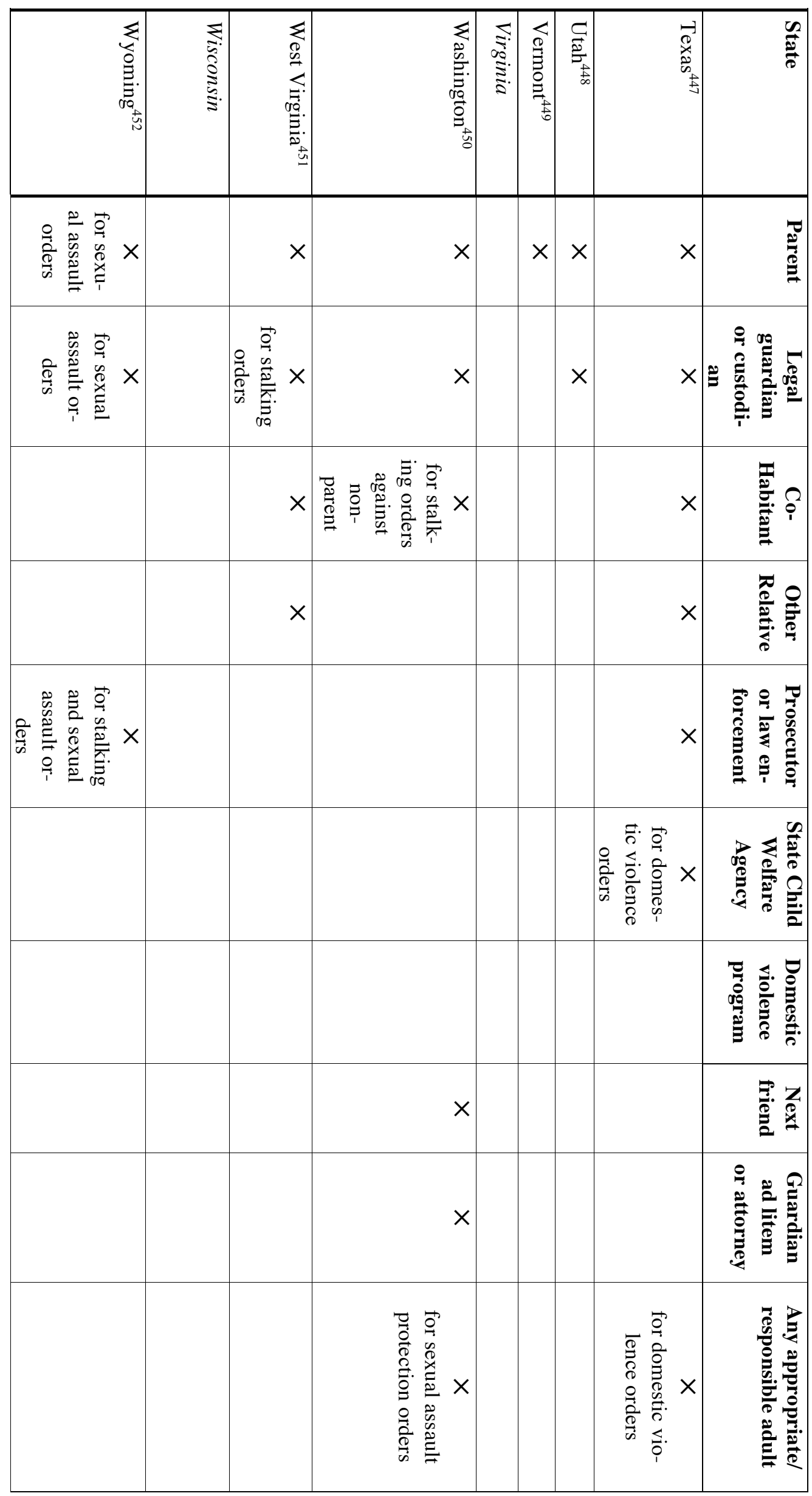




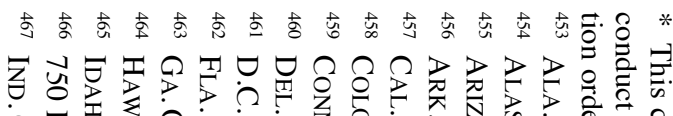
วँ

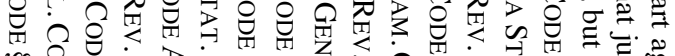

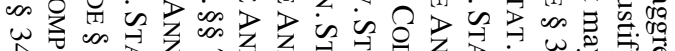

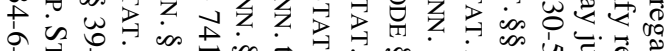
i

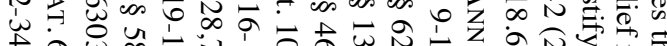
웅해

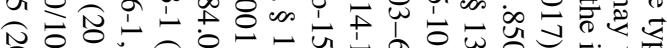

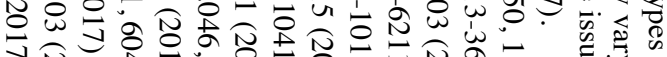

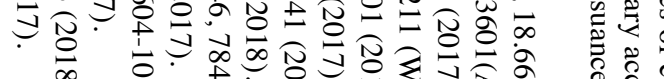

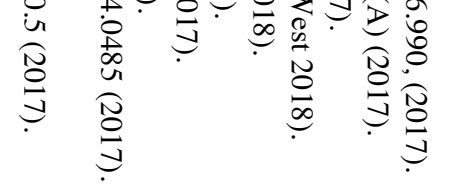

웅.

卷

司完

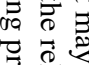
常.

常.

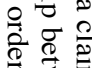

号宫

등

$\stackrel{8}{\stackrel{0}{\circ}}$

을

$\stackrel{9}{9}$

$\stackrel{\text { 尔 }}{2}$

तิ

ণต

离.

育.

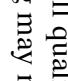

。

完

这

हे 亏े

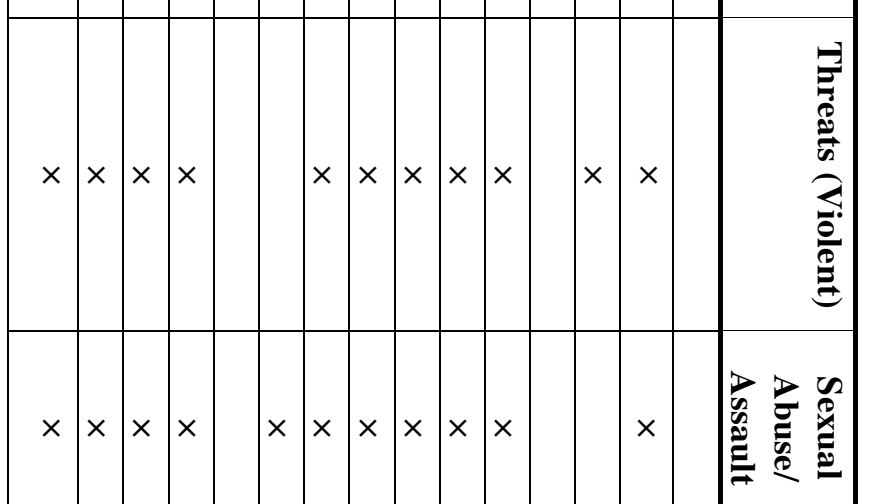

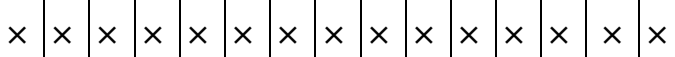
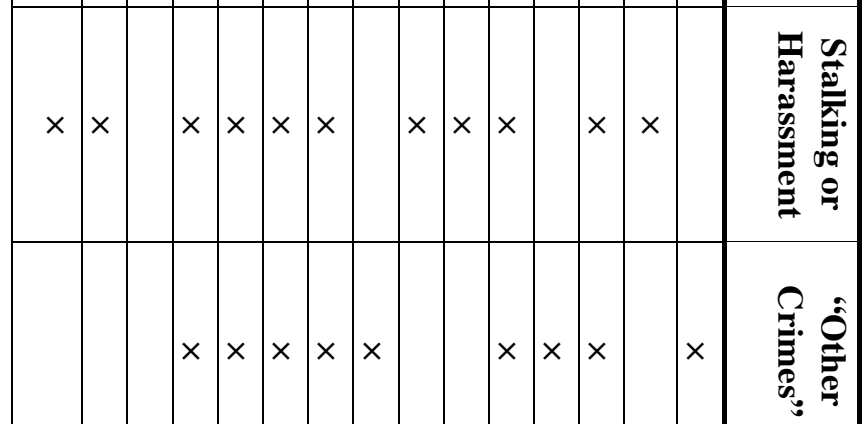

:

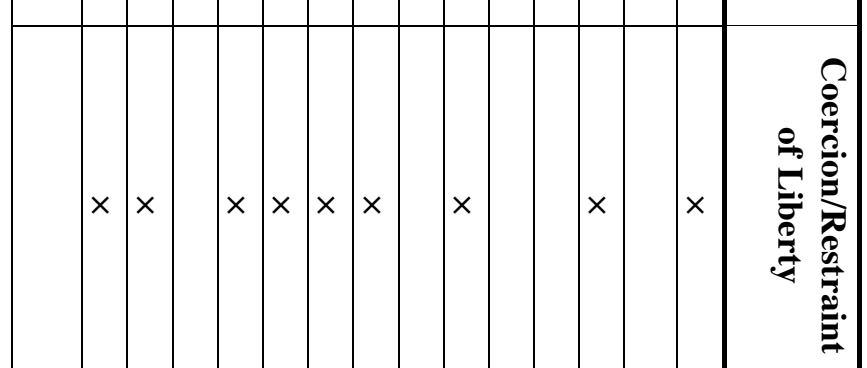

芴

है

$\stackrel{8}{\circ}$

高志.

त.

‥

官

룽

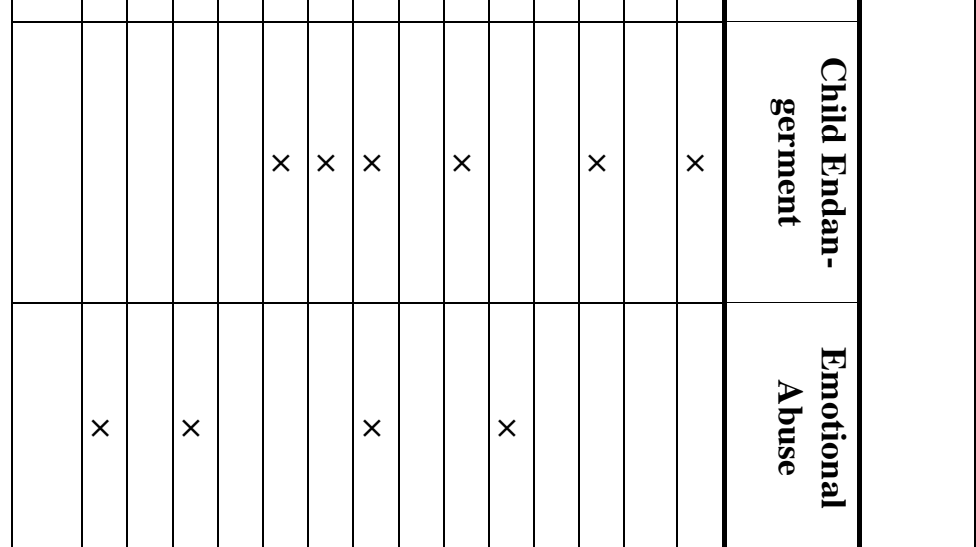




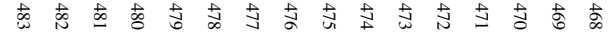

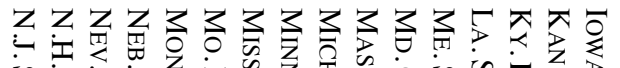

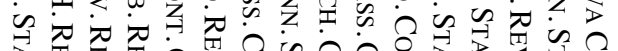

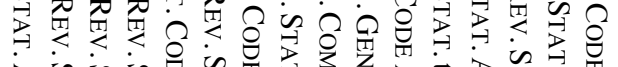

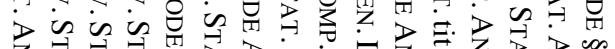

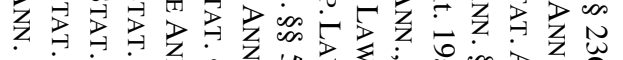

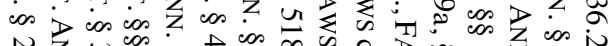
ก Z نَّ

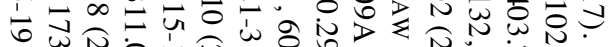

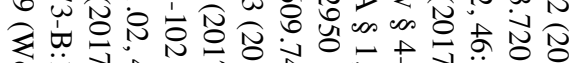

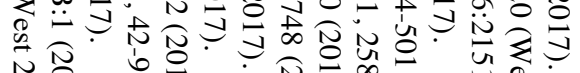

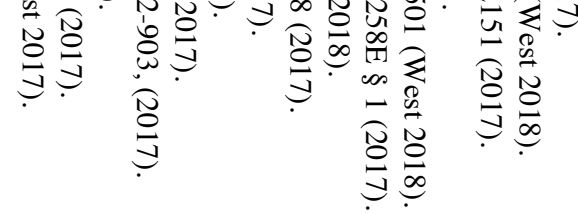

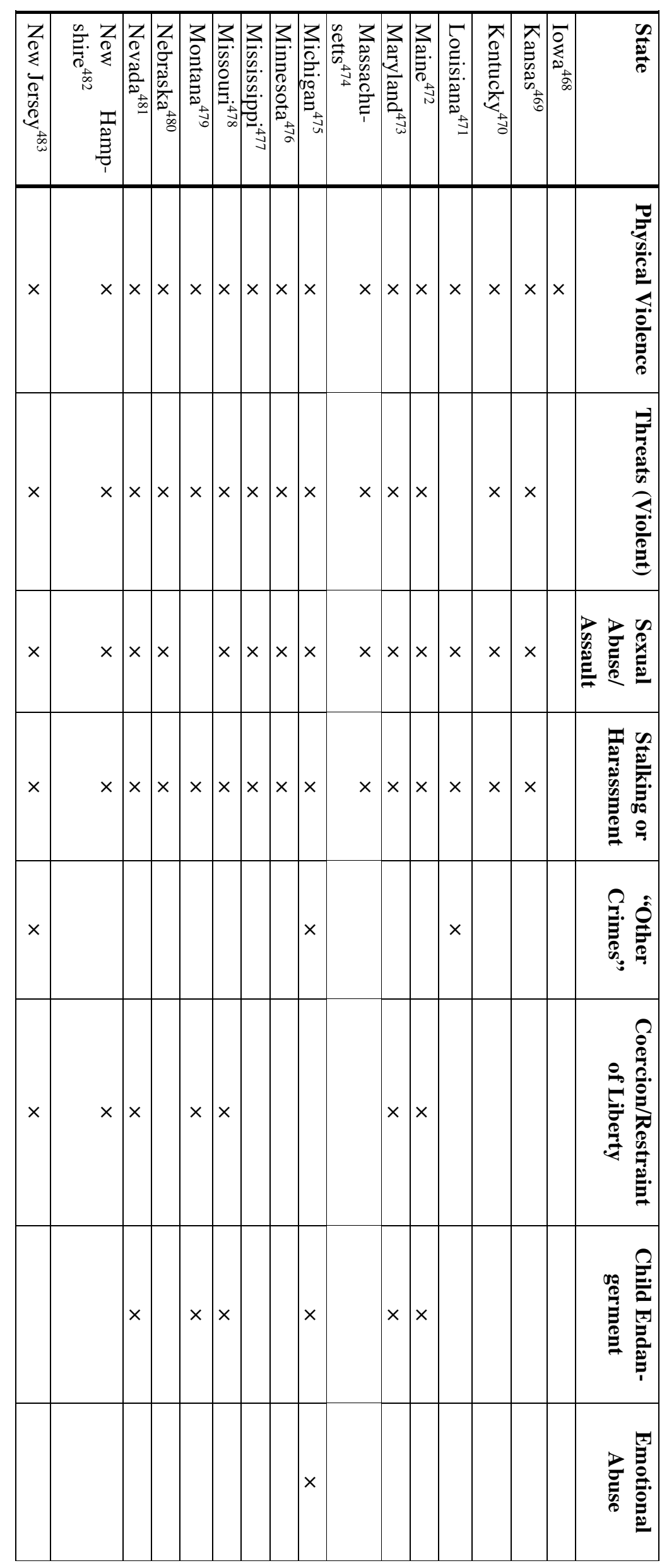



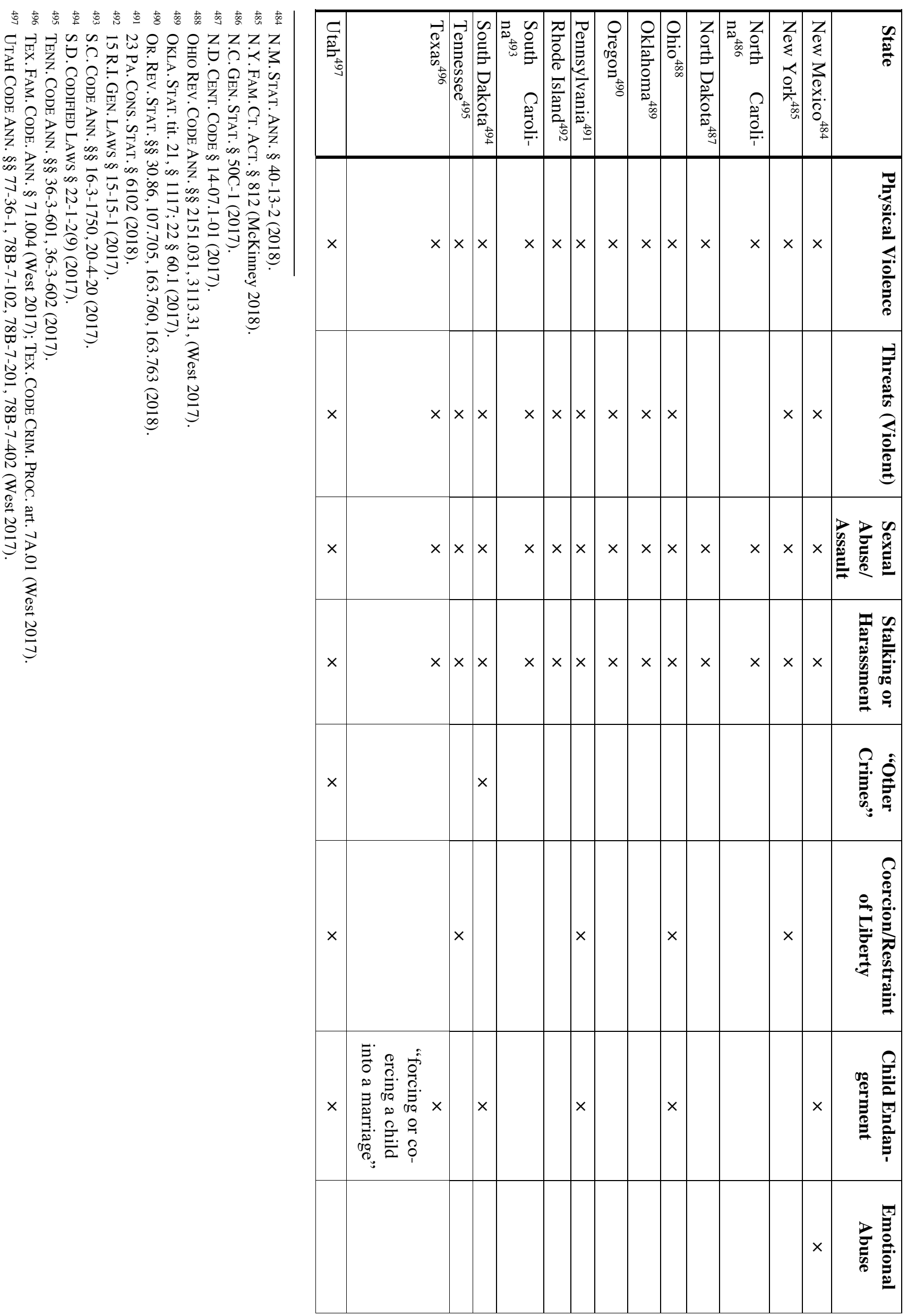

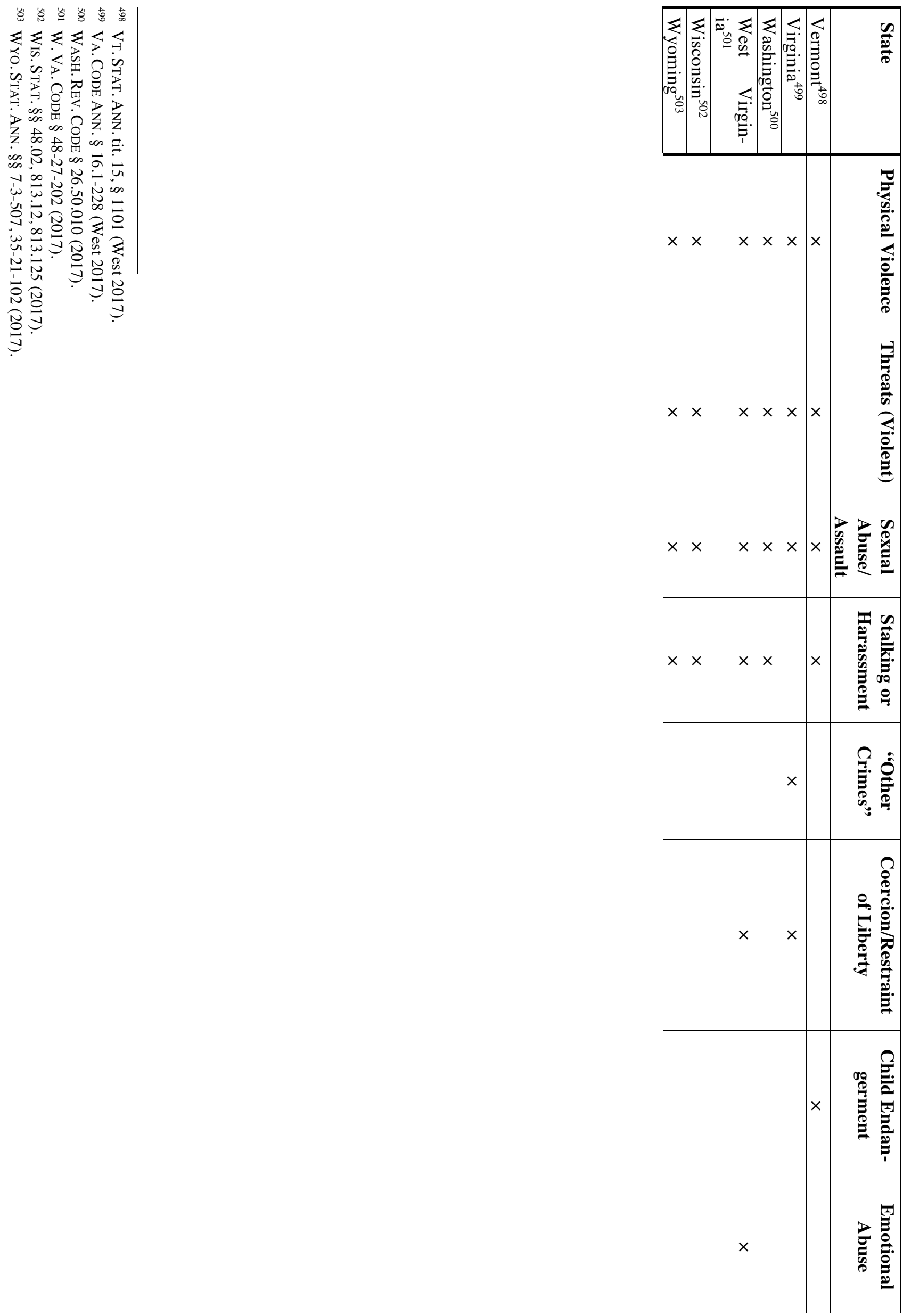


\begin{tabular}{|c|c|c|c|c|c|c|c|c|c|c|c|c|c|c|c|c|c|c|}
\hline 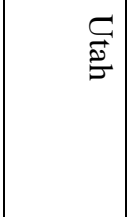 & $\begin{array}{l}\overrightarrow{0} \\
\vec{x} \\
\tilde{\omega}\end{array}$ & \begin{tabular}{|l|} 
\\
\\
0 \\
0 \\
0 \\
0 \\
0 \\
0 \\
0
\end{tabular} & 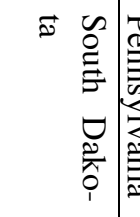 & & $\begin{array}{c}0 \\
\stackrel{0}{0} \\
09 \\
0 \\
9\end{array}$ & 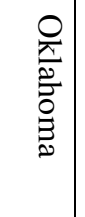 & 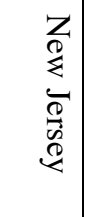 & 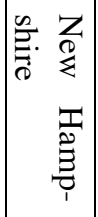 & 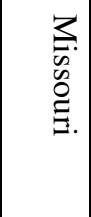 & 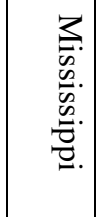 & 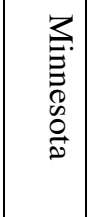 & 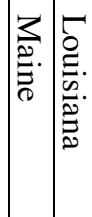 & $\underset{\Omega}{\sigma}$ & 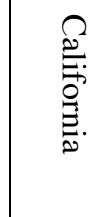 & 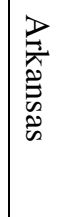 & 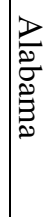 & & \\
\hline 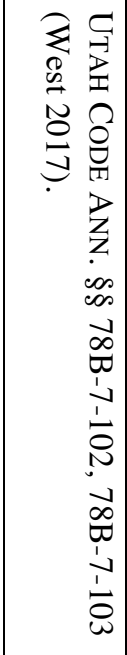 & 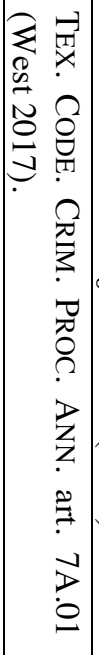 & 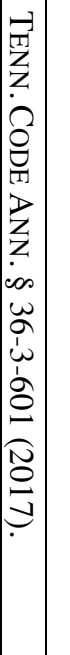 & 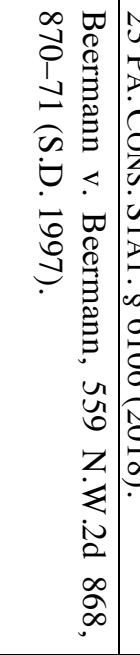 & & 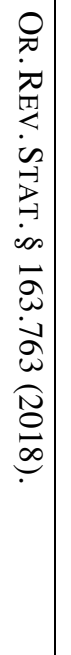 & 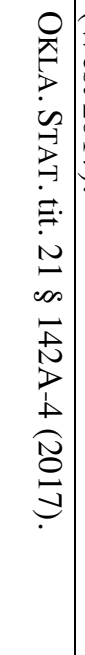 & 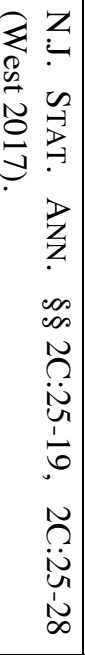 & 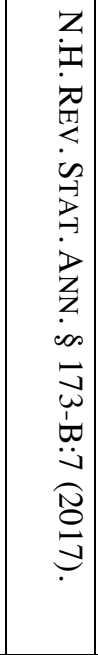 & 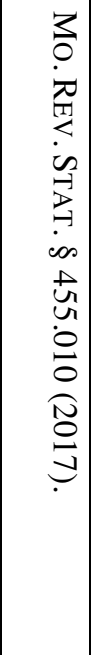 & 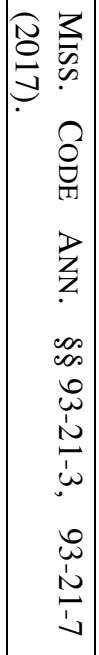 & 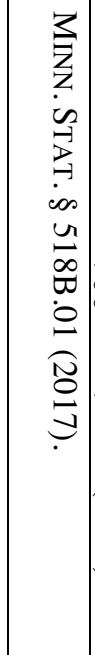 & 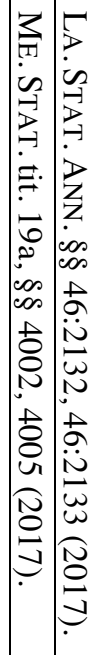 & 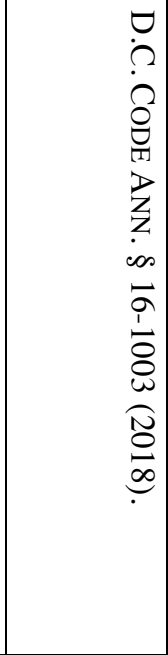 & 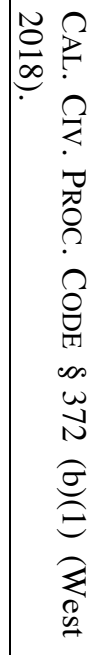 & 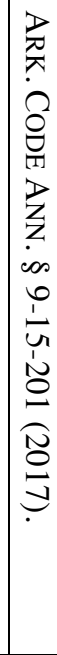 & 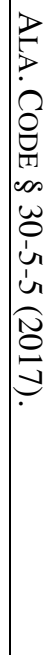 & $\frac{\mathscr{2}}{\hat{\theta}}$ & $\frac{\mathrm{T}}{\mathrm{T}}$ \\
\hline 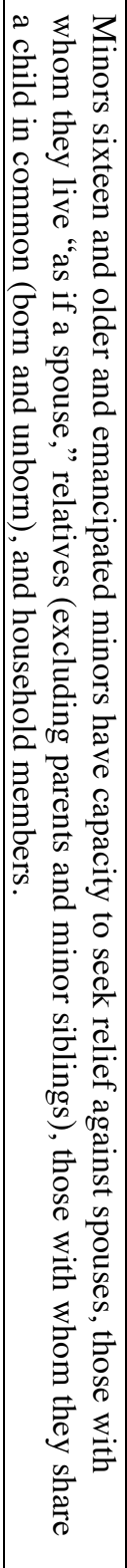 & 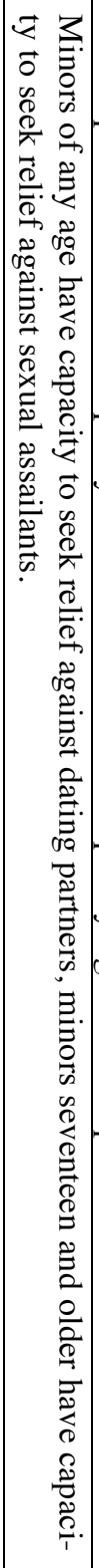 & 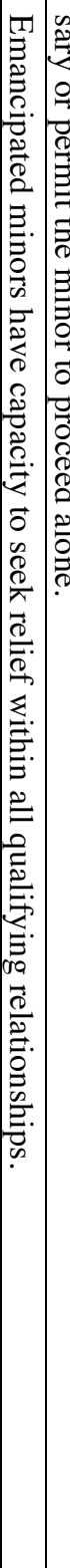 & 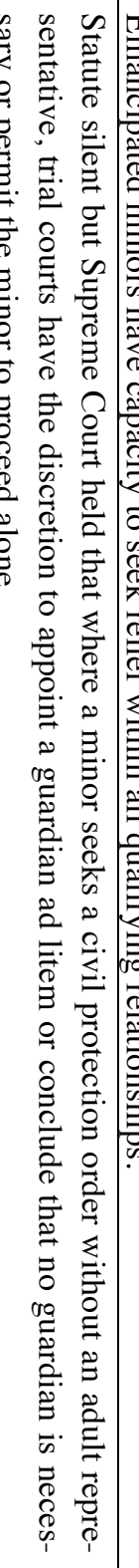 & & 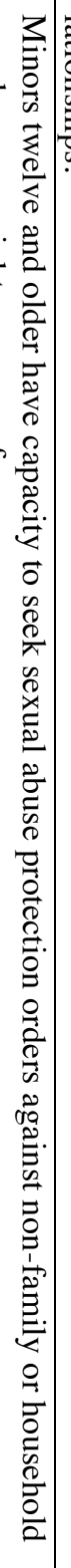 & 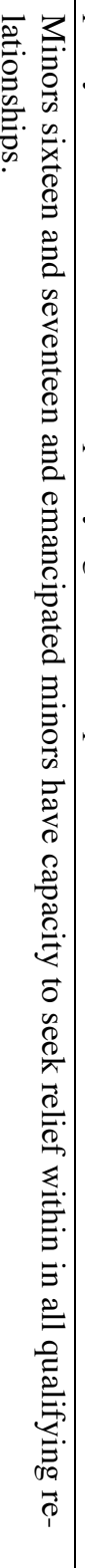 & 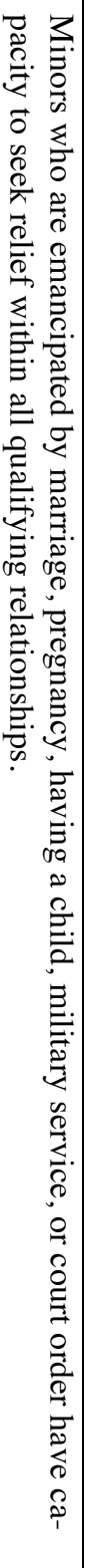 & 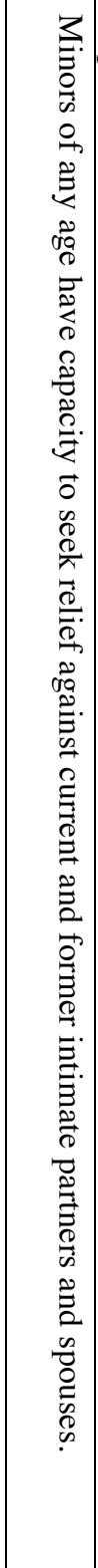 & 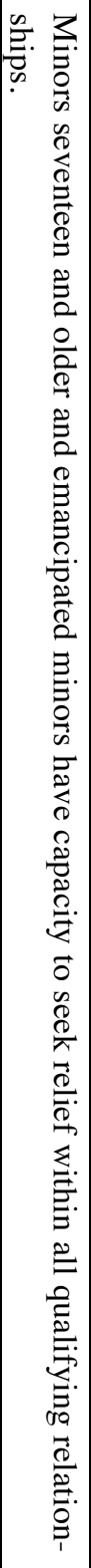 & 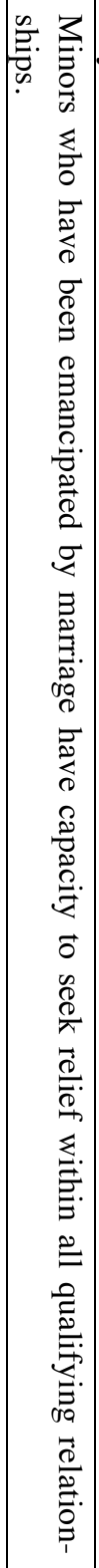 & 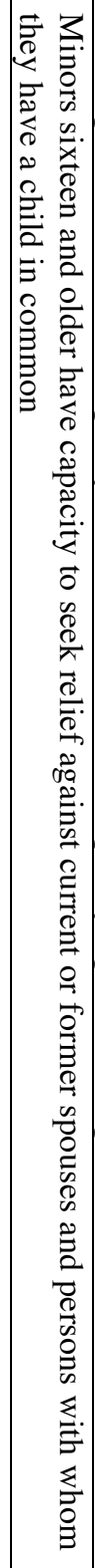 & 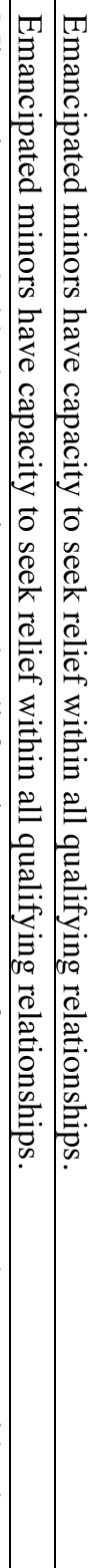 & 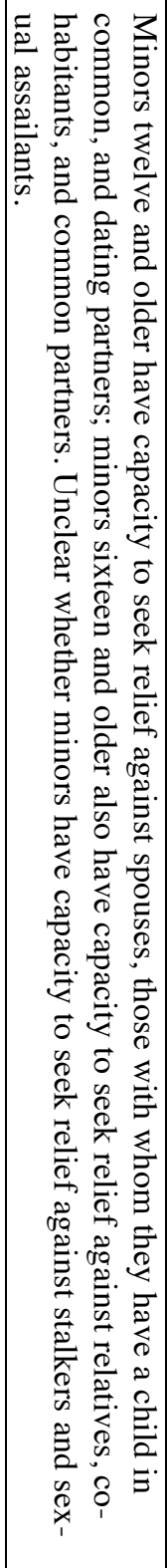 & 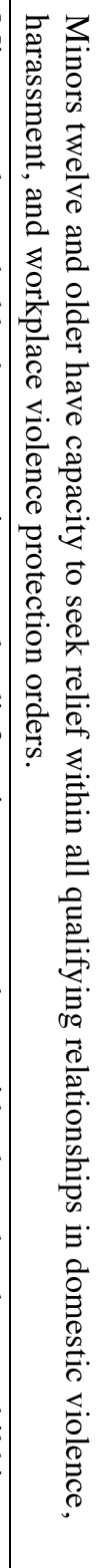 & 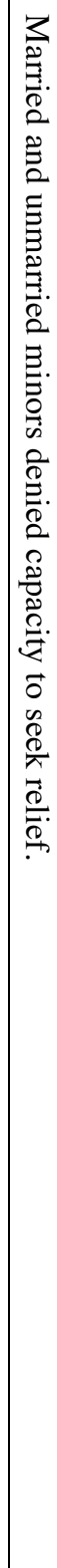 & 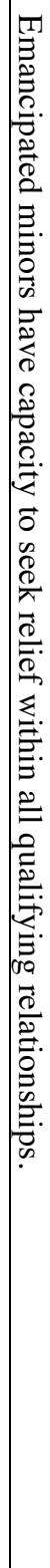 & & 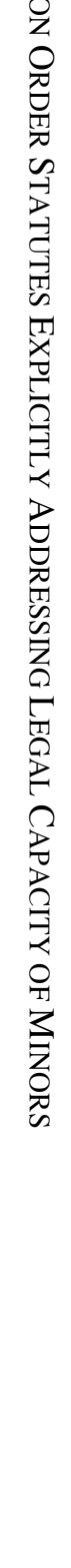 \\
\hline
\end{tabular}




\begin{tabular}{|c|c|c|}
\hline 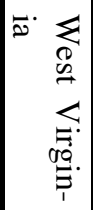 & 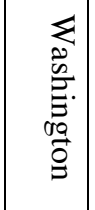 & \\
\hline 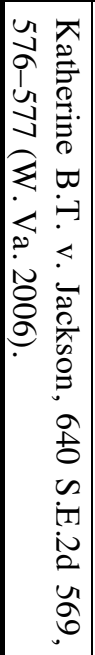 & 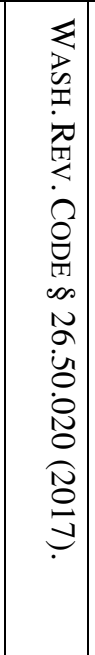 & 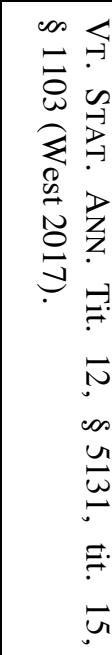 \\
\hline 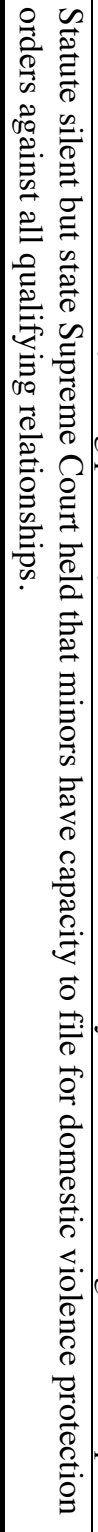 & 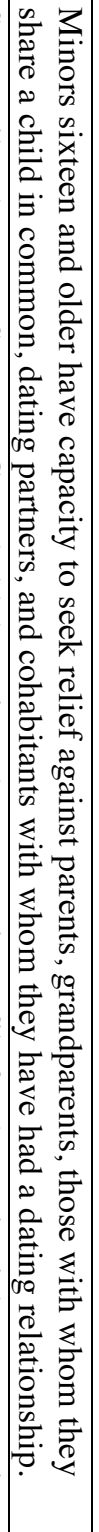 & 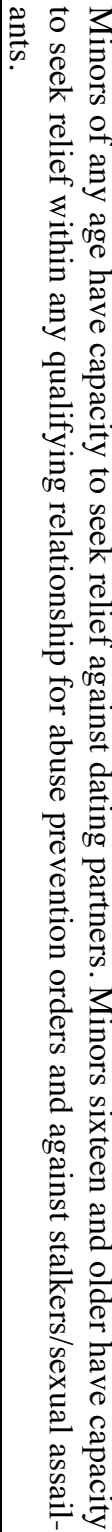 \\
\hline
\end{tabular}




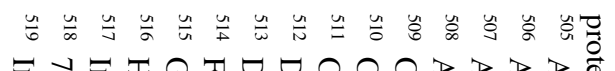

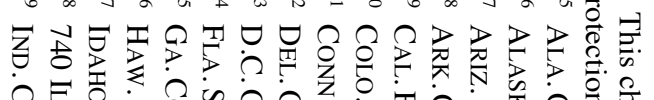
ᄋै

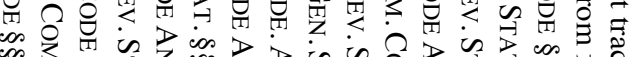

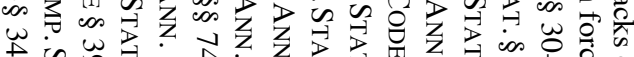

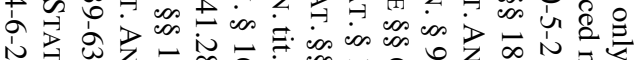

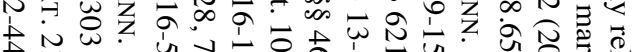

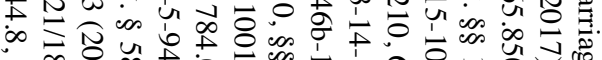

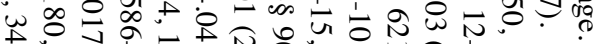
i i

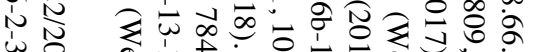

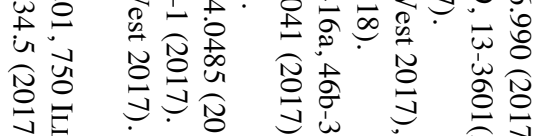

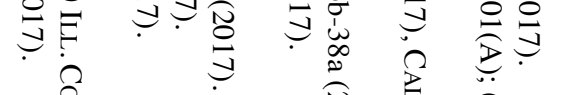

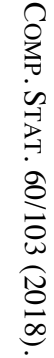

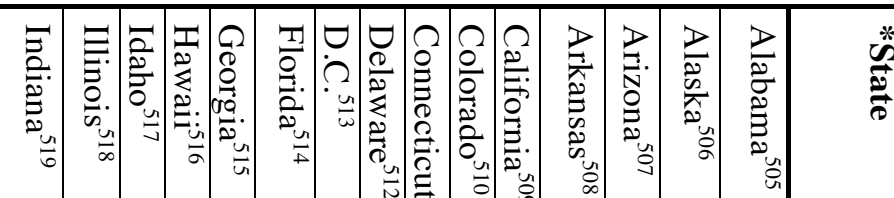

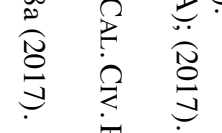

$\times \times \times \times \times \times \times \times \times \times \times \times \times \times$

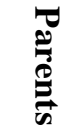

$\times \times \times \times \times \times \times \times \times \times \times \times \times \times$

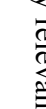

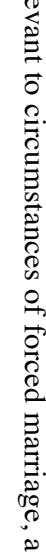

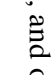

突

$\overrightarrow{0}$

.

要

$\tilde{c}$

$\begin{array}{llllll}x & x \times & \times & \times & \times & \times\end{array}$

$x \times x \quad \times \times \times \times \times \times \times \times \times$

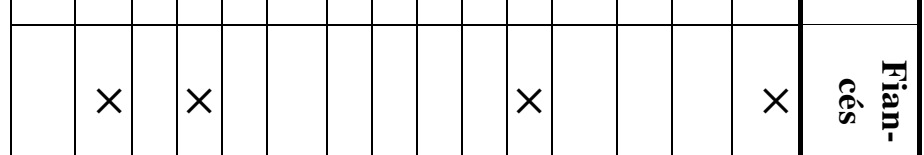

$\times \times \times \times \times \times \times \times \times \times \times$

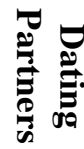

$x \times x \times x \times$ 


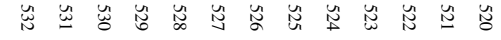

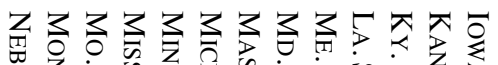

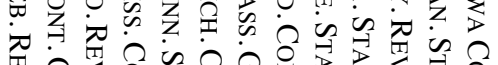

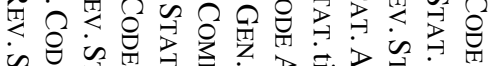

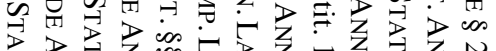

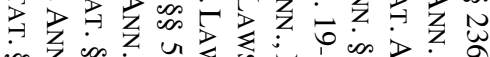

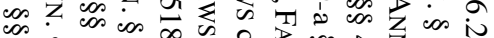

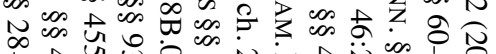
it $\begin{gathered}0 \\ 0\end{gathered}$

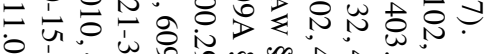

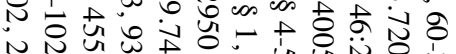

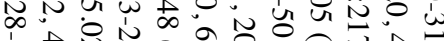

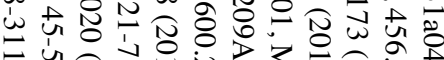

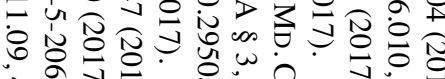

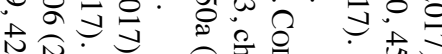

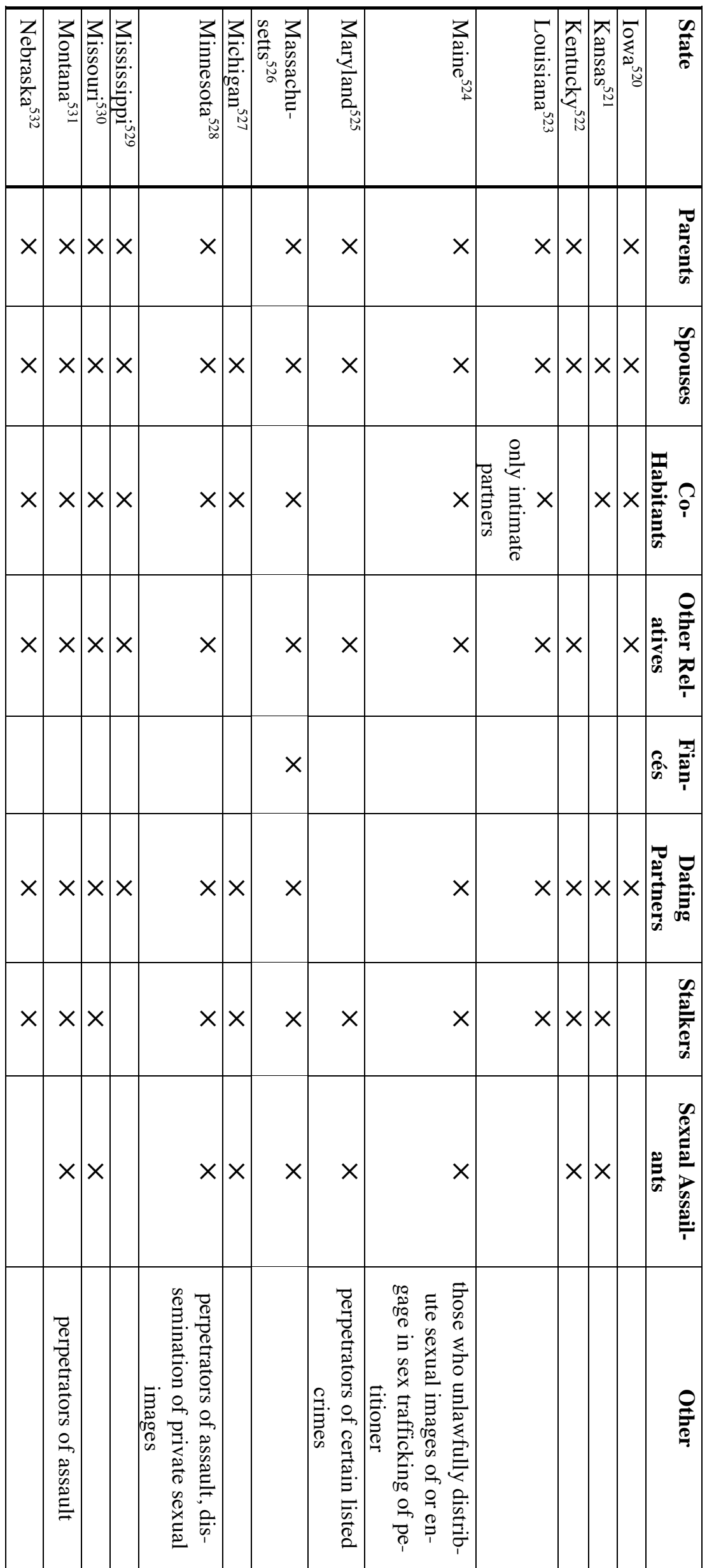
药

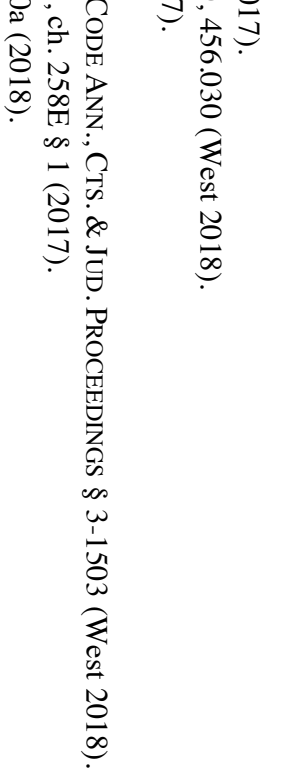




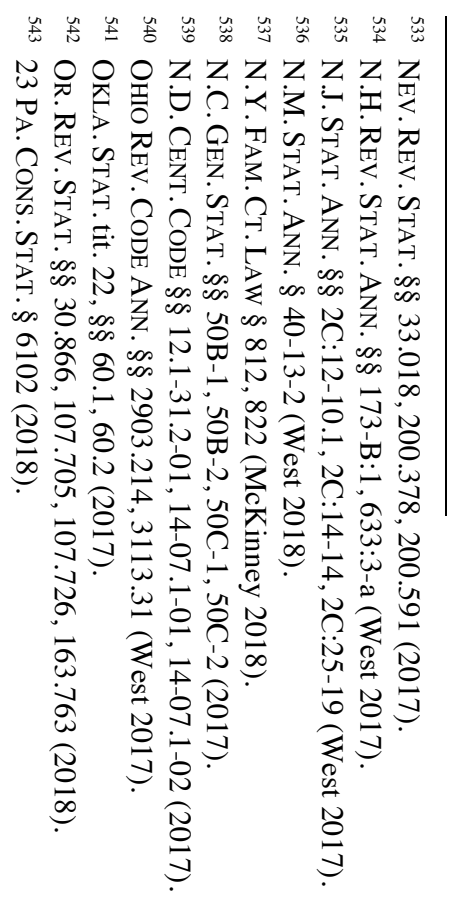

\begin{tabular}{|c|c|c|c|c|c|c|c|c|c|c|c|}
\hline 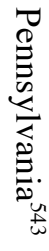 & 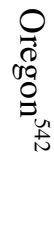 & 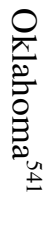 & $\begin{array}{c}0 \\
\stackrel{0}{.} \\
\stackrel{u}{u} \\
\text { bे }\end{array}$ & 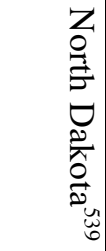 & 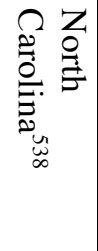 & 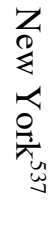 & 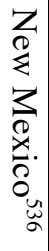 & 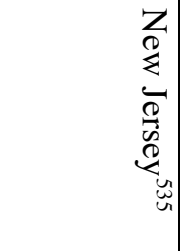 & 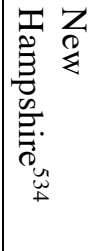 & 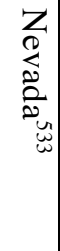 & $\frac{\mathscr{n}}{\overrightarrow{\hat{\theta}}}$ \\
\hline$\times$ & $\times$ & $x$ & $x$ & $\times$ & $\times$ & $\times$ & $\times$ & & $\times$ & $X$ & 胥 \\
\hline$x$ & $\times$ & $x$ & $x$ & $\times$ & $x$ & $\times$ & $\times$ & $x$ & $\times$ & $X$ & 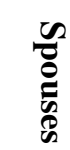 \\
\hline$\times$ & $\times$ & $x$ & $x$ & $\times$ & $x$ & & 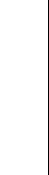 & $\times$ & $x$ & $\times$ & ? \\
\hline$\times$ & $\times$ & $x$ & $x$ & $\times$ & $x$ & $X$ & $x$ & & $x$ & $\times$ & 党: \\
\hline & & $\times$ & & & & & & & & & 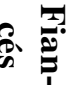 \\
\hline$\times$ & $\times$ & $\times$ & & $\times$ & $\times$ & $\times$ & $\times$ & $\times$ & $x$ & $\times$ & 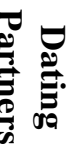 \\
\hline & $\times$ & $\times$ & $\times$ & $\times$ & $\times$ & & $x$ & 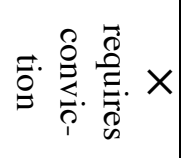 & $x$ & $X$ & 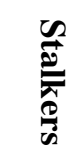 \\
\hline & $x$ & $x$ & $\times$ & & $\times$ & & $\times$ & $\times$ & $x$ & $x$ & 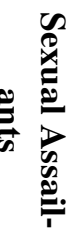 \\
\hline & & & & 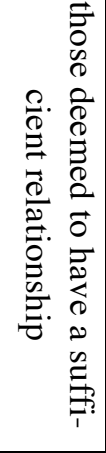 & & & & & & & $\stackrel{?}{\stackrel{9}{9}}$ \\
\hline
\end{tabular}




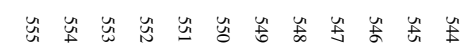

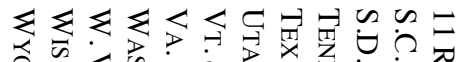

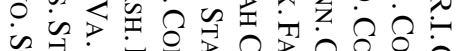

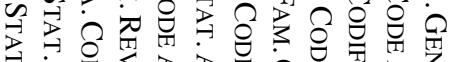

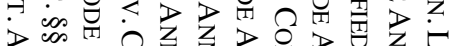

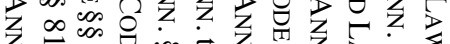

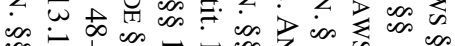

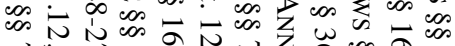

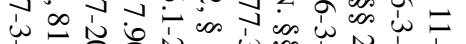

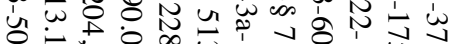

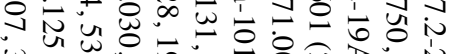
Un

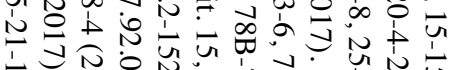

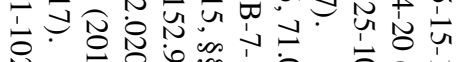
y.

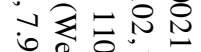

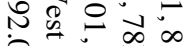

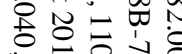

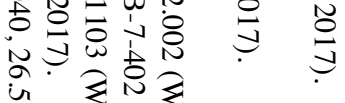

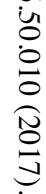
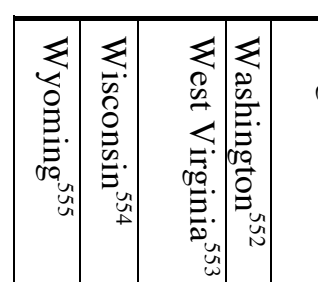

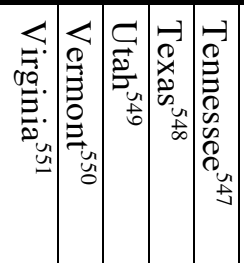
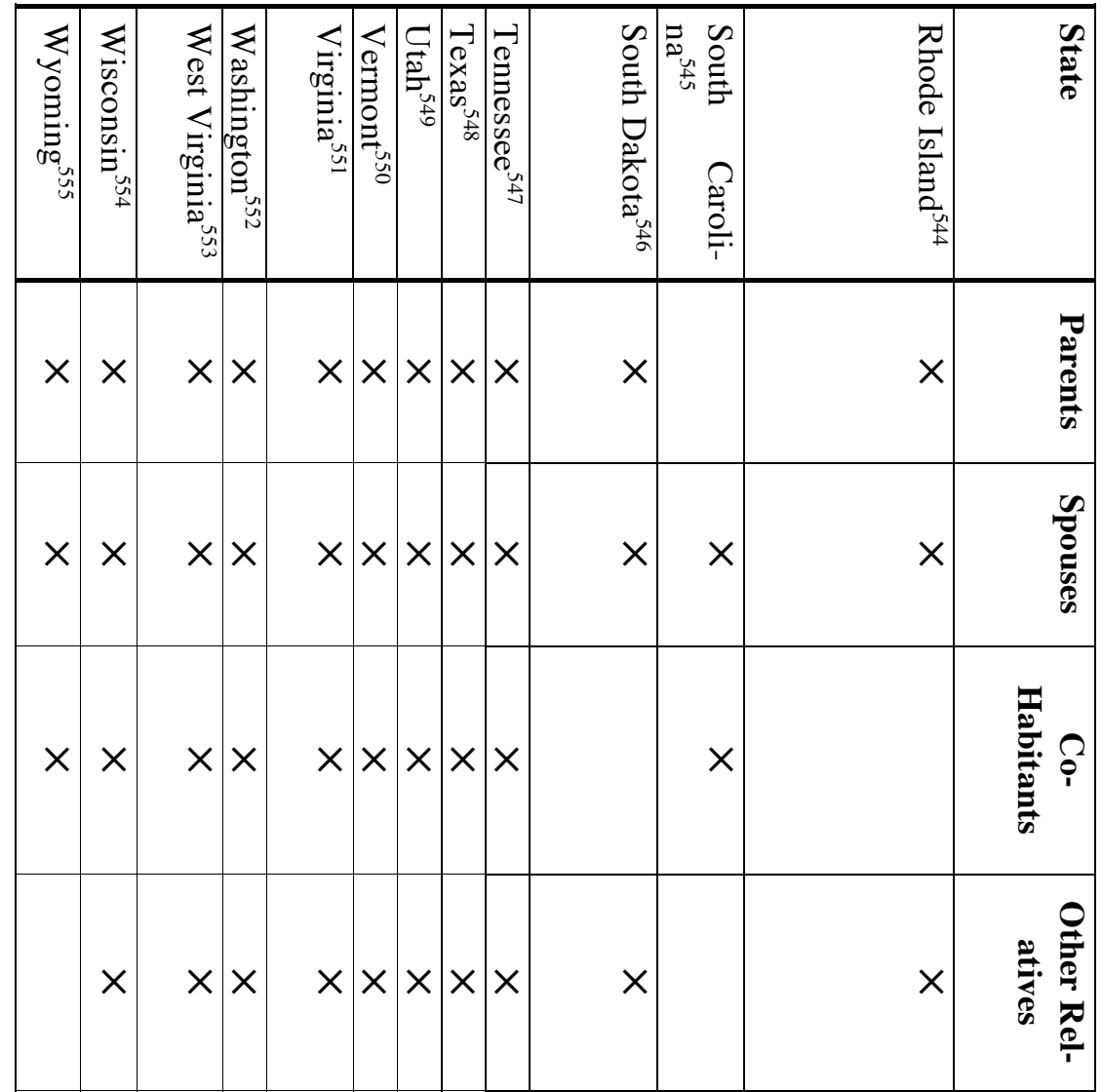

\begin{tabular}{|c|c|c|c|c|c|c|c|c|c|c|c|}
\hline & & & & & & & & & & 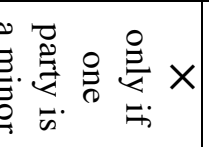 & 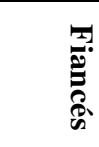 \\
\hline$\times$ & $\times$ & $x$ & $x$ & & $\times$ & $x>$ & $<\times$ & $\times$ & & 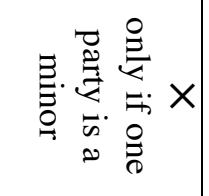 & 总 \\
\hline$\times$ & $\times$ & $x$ & $x$ & & $\times$ & $x>$ & $<\times$ & $\times$ & $x$ & & 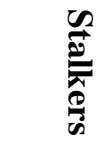 \\
\hline$\times$ & $\times$ & $\times$ & $x$ & & $\times$ & $x$ & $<\times$ & $\times$ & & $\times$ & 营 \\
\hline & 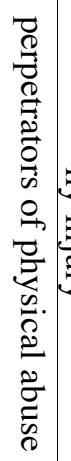 & 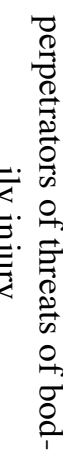 & & 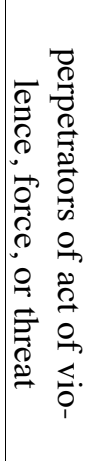 & & & & 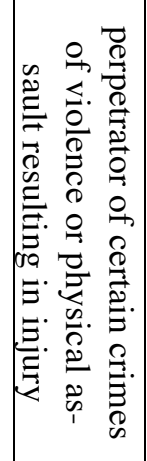 & & & $\stackrel{?}{\stackrel{9}{9}}$ \\
\hline
\end{tabular}




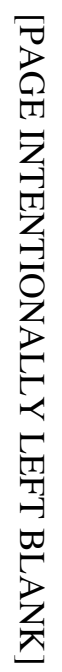

ஓ 


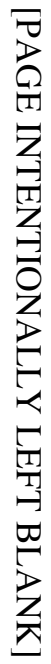




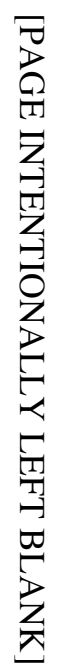

